William de Oliveira Sabino

História natural de Centris (Paracentris) burgdorfi Friese, 1901 (Apidae, Centridini)

Natural history of Centris (Paracentris) burgdorfi Friese, 1901 (Apidae, Centridini)

São Paulo 


\title{
História natural de Centris (Paracentris) burgdorfi Friese, 1901 (Apidae, Centridini)
}

\author{
Natural history of Centris (Paracentris) \\ burgdorfi Friese, 1901 (Apidae, Centridini)
}

(Versão Corrigida*)

Tese apresentada ao Instituto de Biociências da Universidade de São Paulo, para a obtenção de Título de Doutor em Ecologia, na Área de Ecossistemas Terrestres e Aquáticos.

Orientadora: Isabel Alves dos Santos Co-orientadora: Cláudia Inês da Silva

\section{São Paulo}

*A versão original encontra-se disponível no Instituto de Biosciências da USP 
Sabino, William de Oliveira

História natural de Centris (Paracentris) burgdorfi

Friese, 1901 (Apidae, Centridini) / William de Oliveira

Sabino; orientadora Isabel Alves-dos-Santos. -- São

Paulo, 2017 .

$139 \mathrm{f}$.

Tese (Doutorado) - Instituto de Biociências da

Universidade de São Paulo, Departamento de Ecologia.

1. Abelhas coletoras de óleo. 2. Ecologia de

nidificação. 3. Ecologia nutricional. 4. Nicho trófico. 5. Sistema de acasalamento. I. Alves-dos-Santos, Isabel, orient. II. Título.

Catalogação da Publicação

Serviço de Biblioteca do Instituto de Biociências 


\section{Comissão Julgadora}

Prof(a). Dr. Celso Feitosa Martins

Prof(a). Dr. Clemens Peter Schlindwein

Prof(a). Dra. Maria Cristina Gaglianone

Profa. Dra. Isabel Alves dos Santos

Orientadora

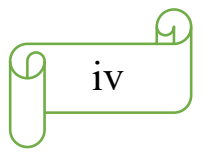




\section{Dedicatória}

À minha mãe Devanir, minha madrinha Márcia e meu falecido avô Abramino sem os quais eu NUNCA teria chegado onde eu cheguei. 


\section{Epígrafe}

"Ecology is a new name for a very old subject. It simply means scientific natural history" Charles Elton, 1927 


\section{Agradecimentos}

Em primeiro lugar agradeço à mãe FAPESP por financiar esse trabalho, tanto aqui no Brasil (Processo $n^{\circ}$ 2013/01580-0) quanto no exterior (processo ${ }^{\circ}$ 2016/003255). Sem esse precioso financiamento nada disso aqui teria ocorrido.

Agradeço às minhas orientadoras Isabel Alves dos Santos e Cláudia Inês da Silva por terem me escolhido para trabalhar com essa maravilhosa espécie ao qual me apaixonei perdidamente, junto àquele cenário paradisíaco que é Natal, RN. Obrigado por isso doutoras! E obrigado pela confiança depositada. Espero não ter decepcionado.

Agradeço ao bugueiro Paulo Roberto de Castro (vulgo Paulão) pelo auxílio de campo em Natal. Nunca vou esquecer das idas "com emoção" pelas dunas de Natal no caminho até os ninhos de Centris burgdorfi.

Agradeço à Astrid Kleinert e ao Felipe Vivallo por terem me acompanhado e ajudado durante todos esses anos durante as reuniões do comitê de acompanhamento.

Aos membros da minha qualificação Reisla Oliveira, Carlos Alberto Garófalo e Roberto Shimizu pelos excelentes comentários que, junto às valiosíssimas contribuições do prof. John Alcock, culminaram na primeira publicação do doutorado.

Aos meus orientadores no exterior, Steve Buchmann e Daniel Papaj que me receberam de braços abertos e me acompanharam em aventuras pelo incrível Deserto de Sonora nos EUA. Aproveito para agradecer à Lilian Schwartz, secretária do Department of Ecology and Evolutionary Biology da University of Arizona, que me ajudou com as pendengas burocráticas em tempo recorde para que eu pudesse fazer meu estágio.

Ao José Elton Nascimento e à professora Elzânia Sales Pereira, da Universidade Federal do Ceará, pela parceria nas análises nutricionais.

A todos os professores do Departamento de Ecologia da USP, pelas excelentes disciplinas que são disponibilizadas todos os anos. Gostaria de ter feito todas elas!

À Vera Lima, secretária do Departamento de Ecologia por ser tão atenciosa e disposta a ajudar os alunos. Vou sentir saudades...

Agradeço a todos os integrantes do BeeLab. Pessoas maravilhosas! Em especial ao Liedson por ser o companheiro dos besteiróis do dia-a-dia e à Sheina por compor o lado da balança que faz com que nossa salinha não exploda diariamente.

À minha esposa Cacau (também conhecida como Ana Carolina), pelo companheirismo durante todos esses anos. Não consigo imaginar uma pessoa que me 
apoie mais hoje em dia do que ela. Sempre ao meu lado independente de momentos triste ou felizes. Devo muito a você, não apenas fora, mas dentro do meu trabalho também. Obrigado pela ajuda em coletas de campo em Natal, escavação de ninhos em pleno deserto nos EUA debaixo de um sol de $45^{\circ} \mathrm{C}$ (e sei o quanto você odeia calor). Obrigado pela medição dos meus grãos de pólen, junto com a Elisa (Elisa, minha filha, muito obrigado por tudo, vc é 10!!), enfim, obrigado por tudo o que tem feito. Te amo muito.

Enfim, agradeço à toda a minha família: mãe, irmãos, padrasto...por todo o apoio. Mãezinha, me desculpe pelas ausências nesses mais de 10 anos de academia. Sei que sente muita a falta de ter os filhos por perto.

E que venha a próxima etapa! 


\section{Índice}

$\begin{array}{ll}\text { Resumo } & 10\end{array}$

Abstract 11

Introdução Geral 12

Capítulo 1. Mating System and Sleeping Behavior of the Male and Female Centris

(Paracentris) burgdorfi Friese (Apidae, Centridini).

Capítulo 2. Nesting biology of the bees Centris (Paracentris) burgdorfi Friese and Centris (Paracentris) pallida Fox (Apidae: Centridini).

Capítulo 3. Plasticity of the trophic niche of Centris (Paracentris) burgdorfi (Apidae, Centridini).

Capítulo 4. Nutritional analysis of diet of two species of Centris (Paracentris) Cameron bees 


\section{RESUMO}

Na presente tese estudei a biologia de Centris (Paracentris) burgdorfi, uma abelha solitária de ampla distribuição no Brasil. O único local de nidificação conhecido até o momento fica em uma área de dunas, no nordeste do Brasil, à $25 \mathrm{~km}$ da cidade de Natal. Neste local as fêmeas nidificam exclusivamente em paleodunas à cerca de $1 \mathrm{~km}$ do mar. Estudei o sistema de acasalamento da espécie, onde pude constatar que a alta competição por fêmeas próxima ao ninho faz com que o macho tenha que retirar a fêmea do local para conseguir o contato genital. Nenhuma fêmea foi vista acasalando mais de uma vez e, logo após a cópula a fêmea dá início à construção do ninho. O ninho é constituído de um túnel raso com acesso às células de cria, construídas uma ao lado da outra. Avaliei o número de viagens que a fêmea faz para a coleta de óleo e pólen e o tempo despendido em cada ação dentro do ninho (deposição de pólen, óleo, ovoposição e operculação). Durante o período de construção das células as fêmeas não dormem dentro do ninho, e sim, em ramos de Krameria tomentosa, a planta utilizada como fonte de óleo no local. Buscando ampliar nosso conhecimento sobre a espécie, procurei outras populações no Brasil para que pudesse avaliar o nicho trófico. Utilizei o pólen encontrado no corpo das fêmeas para inferir sobre a dieta parcial de adultos e imaturos. Além da área de dunas, no Nordeste, encontramos $C$. burgdorfi no cerrado em Cavalcante, Goiás e em áreas de campo de altitude, em Ponta Grossa, Paraná. Através da análise polínica, constatei a importância de plantas do gênero Chamaecrista como fonte de pólen, sendo este um dos poucos gêneros compartilhados entre os três locais. Krameria grandiflora foi a fonte de óleo em Cavalcante e em Natal, e Angelonia integerrima, foi a fonte de óleo no Paraná. Isso revela a amplitude de nicho trófico em $C$. burgdorfi não apenas em relação às espécies de plantas utilizadas na dieta mas, também, quanto ao tipo de elaióforo que a fêmea consegue acessar (epitelial e tricromático). Esta plasticidade possibilita a ampla distribuição da espécie em diferentes fitofisionomias. Analisei nutricionalmente a dieta na provisão da cria de C. burgdorfi do nordeste do Brasil e de células de cria de Centris (Paracentris) pallida, coletadas no sudoeste dos Estados Unidos. Centris pallida é uma espécie de Centridini que perdeu o comportamento da coleta de óleo. Centris burgdorfi possui uma dieta mais rica em lipídeos e proteínas, sendo a dieta de C. pallida mais rica em carboidratos. A dieta mais protéica de C. burgdorfi se deve à presença de Chamaecrista já que plantas que anteras poricidas contem mais proteínas em comparação às não-poricidas, como é o caso das fontes de pólen de C. pallida (Parkinsonia e Olneya).

Palavras-chave: Abelhas coletoras de óleo, ecologia de nidificação, ecologia nutricional, nicho trófico, sistema de acasalamento. 


\begin{abstract}
In the present thesis, I studied the biology of Centris (Paracentris) burgdorfi, a solitary bee of wide distribution in Brazil. The only nesting site known is in a dune area in northeastern Brazil, $25 \mathrm{~km}$ from the city of Natal. In this place, the females nest exclusively in petrified dunes about $1 \mathrm{~km}$ from the sea. I studied the mating system of the species, where I could verify that the high competition by females near the nest forces the male to carry the female to another place to mate. No female was seen mating more than once and, soon after copulation, the female begins to construct the nest. The nest consists of a shallow tunnel with access to the brood cells. I evaluated the number of trips that the female made to the collection of oil and pollen and the time spent in each action within the nest (depositions of pollen, oil, oviposition and operculation). During the period of construction of the cells the females do not sleep inside the nest, but in branches of Krameria tomentosa, the plant used as source of oil. In order to increase our knowledge about the species, I searched for other populations in Brazil so that I could evaluate the trophic niche. I used pollen found in the body of females to infer about the partial diet of adults and immature. In addition to the dune area in the Northeast, I found C. burgdorfi in the Cerrado in Cavalcante, state of Goiás and in high altitude field areas, in Ponta Grossa, state of Paraná. Through pollen analysis, I verified the importance of plants of the genus Chamaecrista as a source of pollen, being this one of the few genera shared among the three sites. Krameria grandiflora was the source of oil in Cavalcante and in the Natal, and Angelonia integerrima, was the source of oil in the Ponta Grossa. This reveals the trophic niche amplitude in C. burgdorfi not only in relation to the species of plants used in the diet, but also to the type of elaiophore that the female can access (epithelial and trichromatic). This plasticity makes possible the wide distribution of the species in different phytophysiognomies. Nutritionally I analyzed the diet in the provision of $C$. burgdorfi offspring from northeastern Brazil and from the breeding cells of Centris (Paracentris) pallida collected in the southwestern United States. Centris pallida is a species of Centridini that has lost the behavior of the oil-collection. Centris burgdorfi has a diet richer in lipids and proteins, and the diet of C. pallida is richer in carbohydrates. The most proteinic diet of $C$. burgdorfi is due to the presence of Chamaecrista, since plants with poricidal anthers contain more proteins compared to non-poricidal ones, such as C. pallida (Parkinsonia and Olneya) pollen sources.
\end{abstract}

Key words: Mating system, nesting ecology, nutritional ecology, oil-collecting bees, trophic niche 


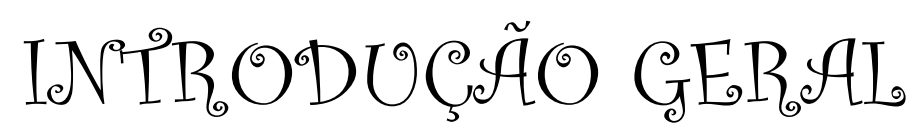




\section{Introdução geral}

A biodiversidade global está decliando a um ritmo alarmante e a perda iminente de importantes serviços ecossistêmicos torna-se uma grande preocupação para os ambientalistas (Luck et al., 2003). Com o atual crescimento do desmatamento e destruição de grandes áreas no Brasil, muitas espécies foram perdidas sem que possamos conhecer sua biologia ou mesmo sua existência.

O estudo da biologia e história de vida dos organismos tem sido uma das abordagens utilizadas para avaliar os efeitos das alterações ambientais nas espécies. Entre os organismos, verificou-se que os insetos são indicadores apropriados para esse fim, devido à sua diversidade e capacidade de produzir várias gerações, geralmente em pouco tempo (Neto et al., 1995). Além disso, os insetos constituem o grupo evolutivamente mais bem-sucedido do mundo, com mais do dobro do número de espécies de todos os outros taxa combinados (Rupert et al., 2005). A diversidade de insetos representa uma variedade equivalente de adaptações a diferentes condições ambientais (Schowalter, 2006).

Dentro da Classe Insecta, os Hymenoptera exibem uma grande diversidade de hábitos e complexidade comportamental, onde se destaca a organização social de vespas, abelhas e formigas (Borror \& DeLong, 2005). As famílias pertencentes a esta ordem são componentes essenciais de vários ecossistemas terrestres, onde atuam como polinizadores (por exemplo, abelhas), controladores populacionais de insetos herbívoros (por exemplo, vespas), como cicladores de nutrientes (por exemplo formigas) e podem ser muito sensíveis a mudanças ambientais (LaSalle \& Gauld, 1993).

As abelhas são insetos intensamente estudados, com uma ampla gama de informações publicadas anualmente (Melo \& Gonçalves, 2005). Eles pertencem à superfamília Apoidea e estima-se que existem mais de quatro mil gêneros e cerca de 25 a 30 mil espécies distribuídas em diferentes regiões do mundo (Michener, 2007), das quais mais de 16.000 foram descritas (Moure et al., 2007). As abelhas são importantes para a manutenção dos ecossistemas terrestres, pois são responsáveis por grande parte da polinização da maioria das angiospermas (Roubik, 1989). Esta estreita relação é baseada na troca de recompensas. A visita floral é motivada por néctar, pólen, 
fragrâncias e outros recursos utilizados por ambas as abelhas adultas como sua prole (Renner, 2006). O Brasil possui uma grande diversidade de abelhas na região Neotropical, com 1.678 espécies descritas, distribuídas em cinco famílias (ou subfamília como em Moure et al., 2007).

\section{Abelhas solitárias}

Algumas espécies de abelhas possuem uma morfologia ou um comportamento especializado para coletar recursos florais de difícil acesso ou explorar recursos específicos (Schlindwein, 2000). Estas guildas de abelhas são formadas quase exclusivamente por espécies solitárias onde não há cooperação e divisão de trabalho entre fêmeas da mesma geração, ou entre mãe e filhas (Michener, 1974). Cerca de 85\% das espécies de abelhas descritas são solitárias (Batra 1984, Michener 2007) (Fig. 1).

\section{Por que estudar ninhos de abelhas solitárias?}

Ao contrário das espécies eussociais, as abelhas solitárias passam grande parte de sua vida construindo e aprovisionando seus ninhos. Fatores que afetam essas atividades como a escolha do local de nidificação e a disponibilidade de alimentos são afetados pela estrutura ambiental (Morato \& Martins, 2006) e, portanto, são assuntos interessantes para estudos em ecologia.

Ninhos de abelhas solitárias são também sistemas apropriados para estudos sobre estratégias de investimento parental porque as fêmeas têm um alto grau de controle sobre o sexo e o tamanho de sua progênie (Bosch, 2008). A teoria de Fisher sobre a alocação sexual prediz que, em uma população panmítica, o investimento dos pais será igualmente distribuído entre machos e fêmeas (Fisher, 1958). Assim, se o custo de produção de uma fêmea for superior ao de um macho, um maior número de machos será produzido (Bosch \& Vicens, 2005). O problema em estabelecer se populações seguem a teoria de Fisher vem da dificuldade associada com a obtenção de medições precisas do investimento parental (Strohm \& Linsenmair, 1999) A medição da energia investida na produção de progênie apresenta problemas práticos óbvios, tornando necessário fazer estimativas indiretas como a alocação de alimento na célula ou tamanho do corpo da prole (Bosch \& Vicens, 2005). 

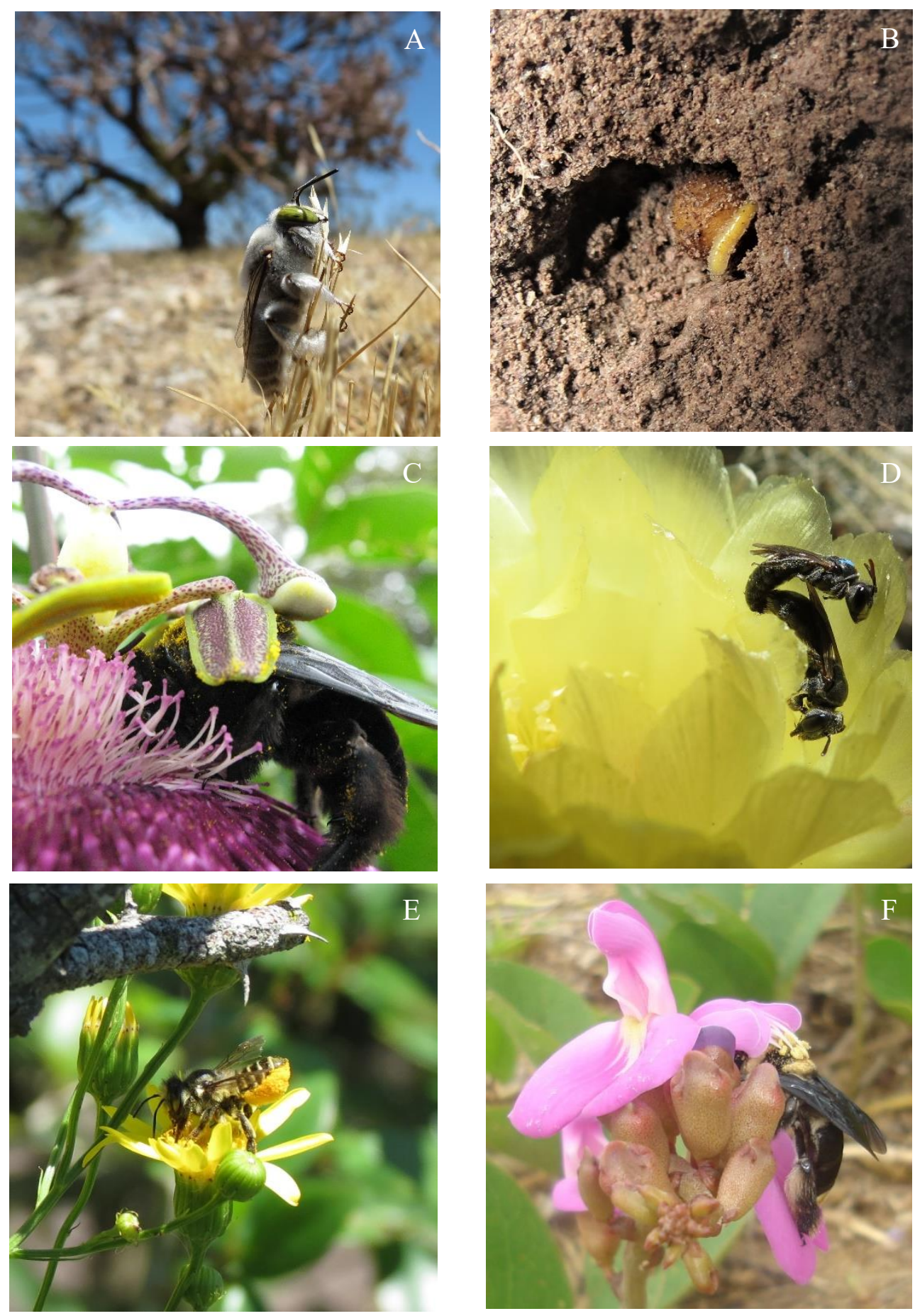

Figura 1. O comportamento solitário é o mais comum entre todas as espécies de abelhas. A alta diversidade torna este sistema ideal para estudos de estratégias populacionais e de vida. A) Macho de Centris pallida; B) Larvas de Hesperapis rhodocerata; C) Fêmea de Xylocopa sp.; D) Casal de Anthrenoides micans; E) Fêmea de Megachile sp.; F) Fêmea de Centris flavifrons.

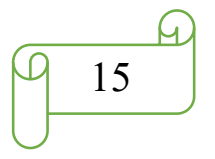




\section{Muito além de apenas pólen e néctar}

Pólen e néctar são as principais recompensas oferecidas pelas flores aos visitantes em troca de seus serviços como agentes polinizadores (Simpson \& Neff, 1981). Mas Vogel (1969) observou que certas flores oferecem lipídios em vez de néctar, proporcionando um novo sistema de polinização. Este sistema envolve 11 famílias de plantas que ocorrem principalmente em regiões tropicais e subtropicais do planeta (Renner \& Schaefer, 2010). Estas plantas produzem óleo floral nas glândulas secretoras chamadas elaióforos, que podem estar na forma de epitélio (Fig. 2A), como visto em Malpighiaceae e Krameriaceae, ou tricomas (Fig. 2B) como Calceolariaceae, Cucurbitaceae, Iridaceae, Myrsinaceae, Plantaginaceae, Scrophulariaceae, Solanaceae e Stilbaceae (Vogel 1974, Buchmann 1987, Alves-dos-Santos et al., 2007). O óleo consiste principalmente em mono- e diglicéridos juntamente com alguns triglicéridos e ácidos graxos livres (Buchmann 1987, Vinson et al., 1997). A falta de coerência filogenética entre essas famílias e a ocorrência esporádica desse sistema dentro das famílias sugerem que a secreção de óleo evoluiu de forma independente várias vezes (Simpson et al., 1990). Embora o óleo contenha mais energia por unidade de volume do que o açúcar, também é mais caro para ser produzido pelas plantas (Buchmann, 1987).

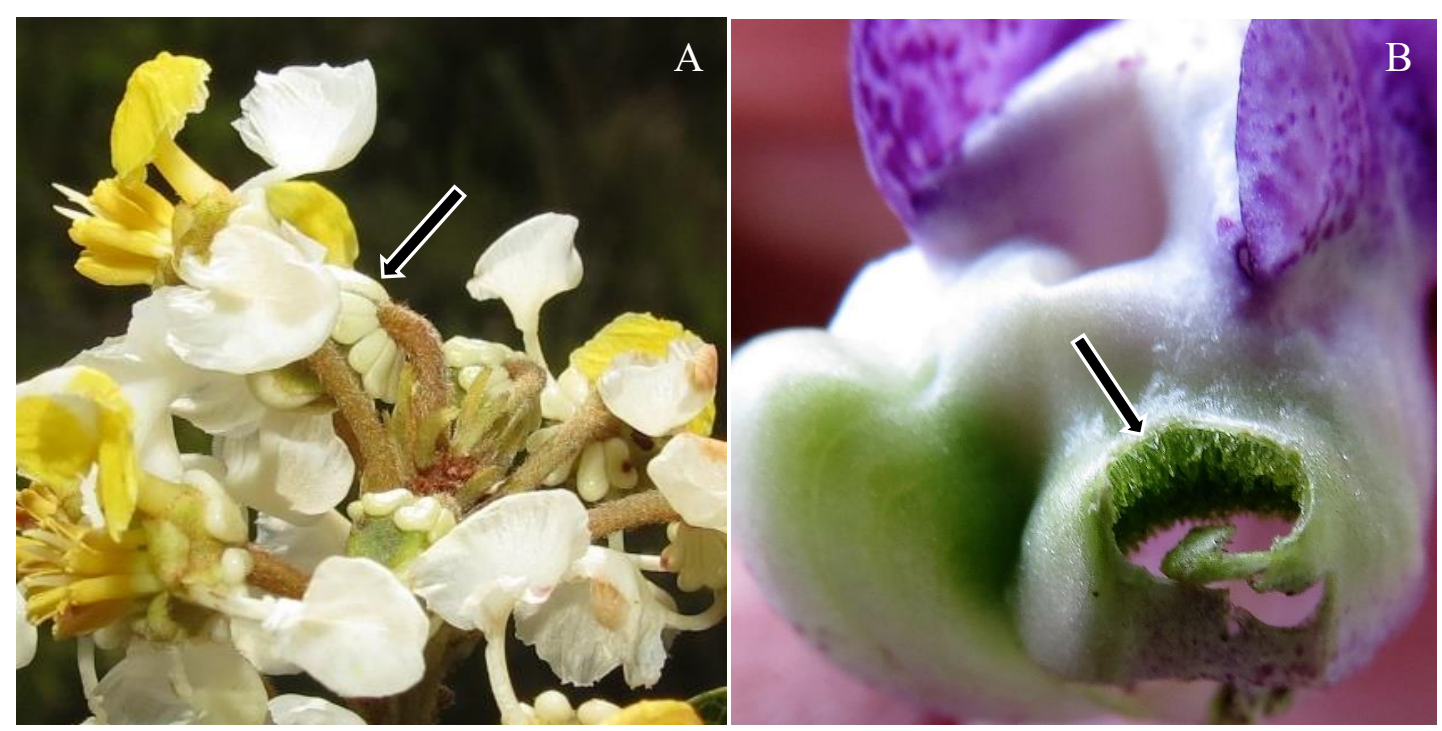

Figura 2. Os dois tipos de elaióforo (ambos destacados com uma seta): o elaióforo epitelial em Byrsonima (A) onde a abelha tem que rasgar a estrutura para coletar o óleo e o elaióforo tricomático em Angelonia (B), onde o óleo é mais facilmente coletado. 
As abelhas que coletam e usam óleos florais ocorrem tanto no Novo como no Velho Mundo, mas são mais diversas nas áreas tropicais e subtropicais do continente americano ou do hemisfério ocidental (Buchmann, 1987). Na maioria das vezes o óleo é usado, tanto para a construção das células de cria como para a nutrição dos imaturos (Buchmann 1987, Vogel 1974). O uso de óleo floral como disposição larval também pode estar relacionado ao alto teor de umidade do solo onde essas abelhas nidificam (Neff \& Simpson, 1981).

Nutricionalmente, por muito tempo, o néctar e o pólen foram considerados como os mais importantes, ou mesmo os únicos benefícios nutritivos (Machado, 2004). Néctar, que contêm carboidratos e aminoácidos e pólen, rico em proteínas e aminoácidos, há muito são reconhecidos como recursos vitais para as abelhas (Baker \& Hurd, 1968). O óleo floral é uma fonte importante de energia para as abelhas coletoras de óleo. Muitas espécies de Centris usam somente o óleo enquanto outras adicionam o néctar ao alimento larval (Vogel 1974, Simpson et al. 1977, Vinson et al., 1997).

\section{Abelhas coletoras de óleo}

As flores produtoras de óleo são visitadas e polinizadas por abelhas coletoras de óleo encontradas em duas famílias: Melittidae e Apidae (Buchmann 1987, Vinson et al. 1997). O comportamento de coleta de óleo provavelmente evoluiu de forma independente em cinco grupos de abelhas (Alves-dos-Santos et al., 2006).

Família Mellitidae

A família Mellitdae é encontrada principalmente na África e na região Holártica.

- Em várias abelhas coletoras de óleo, espécies Rediviva as pernas dianteiras são alongadas, às vezes mais do que todo o corpo (Kuhlmann \& Hollens, 2015). O comprimento da perna dianteira está fortemente correlacionado com comprimentos de esporão floral de plantas hospedeiras de Diascia (Scrophulariaceae) (Steiner \& Whitehead, 1990). As abelhas Rediviva usam suas pernas dianteiras alongadas para coletar os tricomas secretores de óleo escondidos nas pontas de esporas florais emparelhadas de flores de Diascia (Steiner \& Whitehead, 1991).

-Macropis, por outro lado, estão fortemente associados com Lysimachia (Myrsinaceae) (Cane et al. 1983, Vogel 1976). As abelhas desse gênero exibem adaptações morfológicas, como pelos típicos nas pernas, para coletar óleo (Michener, 1981).

Família Apidae 
A família Apidae contém a grande maioria dos gêneros e espécies de abelhas que coletam óleos florais, agrupados em quatro tribos: Ctenoplectrini, Centridini, Tapinotaspidini e Tetrapediini (Machado, 2004). As três últimas tribos são exclusivas do continente americano e especialmente diversas na região Neotropical (Gaglianone et al., 2011).

Ctenoplectra usa o abdômen para coleta de óleo (Vogel, 1981). Este gênero ocorre na África do Sul, acompanhando Momordica (Cucurbitaceae), um de seus dois gêneros hospedeiros conhecidos (Vogel, 1984). A abelha acessa os elaióforos, balançando seu abdômen lateralmente para coletar a secreção (Vogel, 1981).

-Tapinotaspidini é a mais diversificada em termos de estruturas morfológicas e adaptações para coletar o óleo floral porque suas pernas dianteiras e/ou médias são principalmente compostas de grupos de cerdas especializadas (Roig-Alsina 1997, Aguiar \& Melo 2009).

-Tetrapediini é composta por dois gêneros: Tetrapedia e Coelioxoides. Apenas as abelhas Tetrapedia coletam óleo floral (Alves-dos-Santos et al., 2002). Ao contrário da maioria das outras abelhas coletoras de óleo, machos e fêmeas deste gênero exibem uma variedade de características morfológicas e comportamentais para a coleta efetiva de óleos florais (Neff \& Simpson 1981, Cappellari et al. 2012). Coelioxoides é cleptoparasita de Tetrapedia.

-Centridini é composta por dois gêneros: Centris e Epicharis. Eles formam a linhagem mais antiga de abelhas coletoras de óleos florais, principalmente associadas com a família Malpighiaceae, em uma história de 90 Ma de co-evolução (Martins et al., 2014). O gênero Epicharis é exclusivamente neotropical e, aparentemente, todas as espécies cavam seus ninhos no solo (Silveira et al., 2002). As fêmeas de Epicharis coletam óleo apenas de Malpighiaceae (Martins et al., 2015).

\section{O gênero Centris}

Existem 250 espécies válidas de Centris, agrupadas em 12 subgêneros, mas todo o gênero está passando por avaliações recentes (e.g. Vivallo 2014, 2015, 2016, Vivallo \& Vélez 2016, Vivallo et al., 2016).

Centris tem uma ampla distribuição na América do Sul, América Central e sul da América do Norte, onde algumas espécies perderam estruturas e comportamento de coleta de óleo (Neff \& Simpson 1981, Zanella 2002). A perda dos aparelhos coletores de óleo, como observado em C. pallida, por exemplo, e consequentemente a não 
dependência de óleos florais, ocorreu independentemente pelo menos duas vezes em Centris (Neff \& Simpson 1981, Martins \& Melo 2015).

Os subgêneros reconhecidos em Centris são: C. (Aphemisia), C. (Centris), C. (Hemisiella), C. (Heterocentris), C. (Melacentris), C. (Paracentris), C. (Penthemisia), C. (Ptilocentris), C. (Ptilotopus), C. (Trachina), C. (Wagenknechtia) e C. (Xanthemisia) (Moure et al., 2007), com grandes diferenças nos hábitos de nidificação (Coville et al., 1983). Espécies dos subgêneros Centris, Melacentris, Paracentris, Penthemisia, Trachina e Wagenknechtia cavam seus ninhos no solo ou em ravina (e.g. Coville et al. 1983, Rozen \& Buchmann 1990, Camilo et al. 1993, Chiappa \& Toro 1994, Moure 2002, Martins et al. 2014). O subgênero Ptilotopus é frequentemente associado a ninhos de cupim (e.g. Gaglianone 2001, Ramos et al. 2007). As espécies de Hemisiella, Heterocentris e Xanthemisia nidificam em cavidades preexistentes e podem utilizar células abandonadas de vespas e abelhas, em buracos de madeira, troncos de árvores e ninhos-armadilha (e.g. Jesus \& Garófalo 2000, Aguiar \& Martins 2002, Couto \& Camilo 2007, Mendes \& Rêgo 2007). Não há informações sobre a biologia de nidificação de Aphemisia e Ptilocentris.

Os ninhos das espécies Centris são atacados, principalmente, por um grupo de abelhas cleptoparasitas neotropicais da tribo Ericrocidini (Vivallo \& Melo, 2010).

\section{A coleta de óleo floral}

As abelhas coletoras de óleo têm estruturas especiais para coletar óleo floral. O óleo é transferido diretamente das pernas dianteiras para as escopas da perna traseira de modo ipsilateral (Neff \& Simpson, 1981). Uma combinação de cerdas gigantes e pentes presentes nas pernas anteriores e médias é responsável pelo comportamento da coleta de óleo. A maioria das espécies de Centris e Epicharis tem uma cerda gigante bem desenvolvida e ápices triangulares e espatulados nas pernas dianteira e média (chamado de padrão fourlegged) (Neff \& Simpson 1981, Taniguchi 2010). Existem variações neste padrão em relação à forma dos pentes e das cerdas e se as estruturas de coleta de óleo estão presentes em duas ou quatro pernas (Fig. 3 A-D). A morfologia e posição dos aparatos de coleta de óleo das abelhas estão correlacionadas principalmente com os tipos de elaióforos florais (Neff \& Simpson, 1981). Pentes bem desenvolvidos com cerdas gigantes são muitas vezes associados com elaióforos epiteliais onde a fêmea deve romper a cutícula cobrindo as células epidérmicas secretoras. A redução das cerdas 
gigantes com um maior alargamento das cerdas está associada à elaióforos tricomáticos em que o óleo é muito mais acessível (Neff \& Simpson 1981, Simpson et al. 1990).
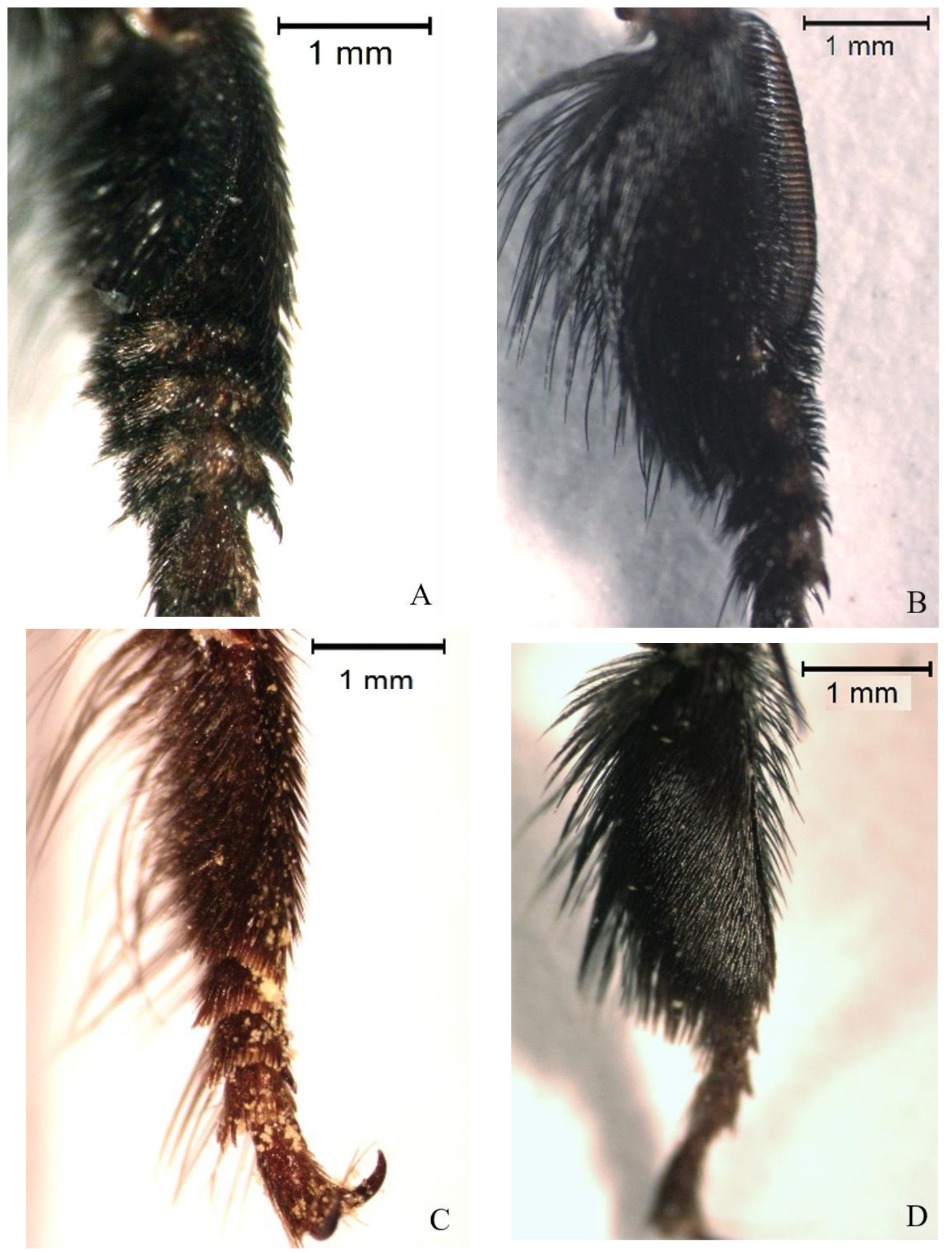

Figura 3. Estruturas coletoras de óleo podem estar presentes ou ausentes mesmo dentro de um subgênero de Centris. Perna anterior (A) e média (B) de uma fêmea de Centris (Paracentris) burgdorfi, com a presença de pentes coletores. A ausência dessas estruturas é vista em Centris (Paracentris) pallida (C, perna anterior e D, perna média), uma abelha que perdeu o comportamento de coleta de óleo. 


\section{A espécie-alvo deste estudo}

Nossa espécie-alvo é Centris (Paracentris) burgdorfi Friese, 1901. Silva et al. (2012) encontraram uma agregação em dunas petrificadas em Natal, RN, Brasil. Esse é o único local de nidificação que conhecemos para a espécie até agora. Através da literatura e da coleta de dados entomológicos (Tab. 1), registramos a distribuição da espécie no Brasil (Fig. 4).

As estruturas de coleta de óleo em $C$. burgdorfi são semelhantes às relatadas para Centris (Paracentris) spp. (Neff \& Simpson 1981, Taniguchi 2010) e são chamados de "fourlegged com modificações": as cerdas gigantes têm o ápice um pouco arredondado e essas modificações são frequentemente relacionadas à coleta de óleo floral em plantas com elaióforos tricomáticos (Vogel 1974, Simpson et al. 1990, Cocucci 1991).
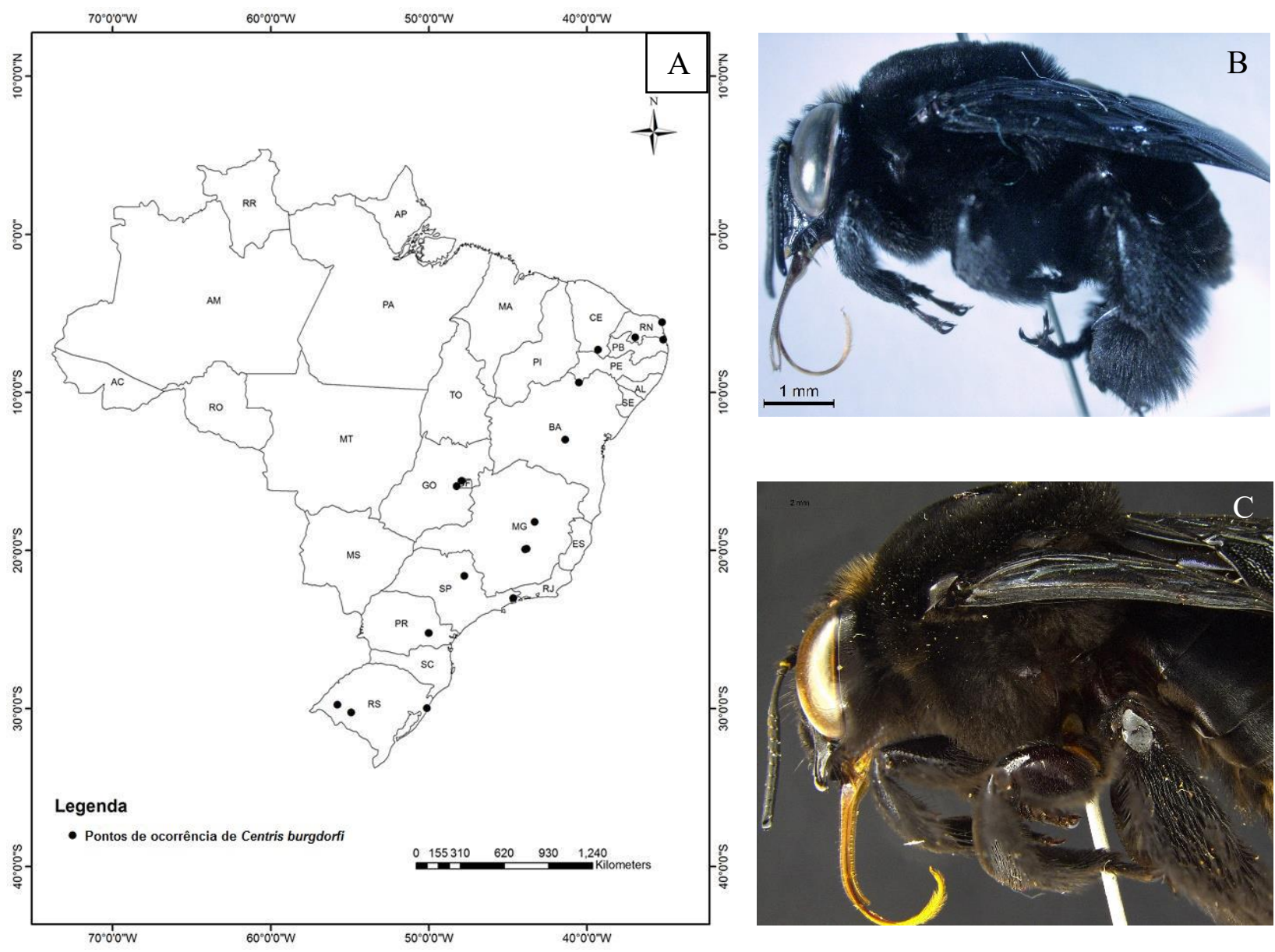

Figura 4. A espécie-chave deste estudo, Centris (Paracentris) burgdorfi. (A) Pontos de ocorrência da espécie obtidos através de dados da literatura. Exemplar de macho (B) e fêmea (C) de C. burgdorfi. 
Tabela 1. Dados de literatura sobre a distribuição de Centris burgdorfi no Brasil e o mês em que os indivíduos foram coletados.

\begin{tabular}{cccc}
\hline Estado & Localidade & Mês de coleta & Referência \\
\hline CE & Barbalha & mai & Zanella, 2002 \\
PE & Petrolina & mai & Zanella, 2002 \\
GO & Santo Antônio do Descoberto & fev & Zanella, 2002 \\
GO & (desconhecida) & - & Simpson, 89 \\
DF & Chapada da Contagem & fev & Zanella, 2002 \\
DF & (desconhecida) & - & Simpson, 89 \\
MG & Belo Horizonte & nov & Zanella, 2002 \\
MG & BH-Parque das Mangabeiras & nov & Zanella, 2002 \\
MG & Sabará- Clube A. Scharlé & set & Zanella, 2002 \\
MG & São Gonçalo do Rio Preto & abr & Martins, 2009 \\
SP & Estação Ecológica Jataí & mar & Zanella, 2002 \\
PR & Parque Estadual Vila Velha & jan & Zanella, 2002 \\
SP/RJ & Parque Nacional da Serra da Bocaina & - & Freitas \& Sazima, 2006 \\
PR & Parque Estadual de Vila Velha & - & Gonçalves et al. 2009 \\
PR & Parque Estadual de Vila Velha & - & Gonçalves \& Melo 2005 \\
RS & Rosário do Sul & nov & Zanella, 2002 \\
RS & Alegrete & nov & Zanella, 2002 \\
RS & Litoral Norte & dez & Vianna \& Alves-dos-Santos, 2002 \\
RN & Deserto dos anjos, Natal & out & Silva et al., 2012 \\
RN & Região do Seridó & - & Carvalho, A. T. (Com. pessoal) \\
PB & Mamanguape, Rebio Guaribas & - & Camarotti, 2004 \\
BA & Chapada Diamantina & - & Aguiar et al., 2005 \\
\hline \hline
\end{tabular}

O relatório está dividido em quatro capítulos. Cada capítulo trata de um manuscrito independente, publicado ou em preparação. Por esta razão, repetições podem ser encontradas em alguns assuntos entre capítulos.

No capítulo 1 descrevemos o comportamento de acasalamento de C. burgdorfi e as estratégias dos machos na busca de fêmeas. Há também novas informações sobre o local onde os machos e as fêmeas passam a noite. No caso das abelhas solitárias, sabese que as fêmeas passam a noite dentro do ninho, enquanto os machos dormem em agregados no campo, geralmente em ramos de plantas. Neste estudo, encontramos o contrário: machos dormindo agregados no local de nidificação enquanto as fêmeas passam a noite no campo presa nos ramos da planta usada como fonte de óleo floral.

No capítulo 2, nosso foco foram as fêmeas. Descrevemos a biologia de nidificação da espécie, avaliando a atividade das fêmeas durante a construção dos ninhos. Foi possível revelar os inimigos naturais da espécie e descobrir que cada fêmea 
gasta, em média, mais tempo para construir cada célula do que outras espécies de Centris.

No capítulo 3 foram analisadas as plantas utilizadas pela espécie como fonte de pólen, néctar e óleo. Seguindo o mapa de distribuição, encontramos C. burgdorfi em outras duas localidades no Brasil: em uma área de Cerrado em Goiás e em uma área de campos de altitude no estado do Paraná. Nas três localidades estudadas, foram coletados pólen do corpo das fêmeas, para analisar o nicho trófico da espécie. Descobrimos que a espécie tem plasticidade no uso de recursos entre populações e é capaz de visitar e coletar óleo floral de plantas com diferentes tipos de elaióforos.

No capítulo 4, analisamos o valor nutricional da provisão. Sabendo que o óleo fornece mais energia do que o néctar, comparamos o valor nutricional do alimento larval de C. (Paracentris) burgdorfi, que usa óleo floral para alimentar as larvas, com a espécie C. (Paracentris) pallida, que perdeu o comportamento de coleta de óleo. Utilizamos ninhos de C. pallida coletados no Deserto de Sonora no Arizona, EUA. Descobrimos diferenças consideráveis entre as duas espécies, não só relacionadas aos lipídios, mas também às proteínas.

\section{Referências bibliográficas}

Aguiar, A. J. C., \& Martins, C. F. (2002). Abelhas e vespas solitárias em ninhosarmadilha na Reserva Biológica Guaribas (Mamanguape, Paraíba, Brasil). Revista Brasileira de Zoologia, 19(Supl 1), 101-116.

Aguiar, A. J., \& Melo, G. A. (2009). Notes on oil sources for the bee genus Caenonomada (Hymenoptera, Apidae, Tapinotaspidini). Revista Brasileira de Entomologia, 53(1), 154-156.

Alves-dos-Santos, I., Melo, G. A. R., \& Rozen, J. G. (2002). Biology and imature stages of the bee tribe Tetrapediini (Hymenoptera: Apidae). American Museum Novitates, 3377, 1-45.

Alves-dos-Santos, I., Naxara, S. R. C., \& Patrício, E. F. L. R. A. (2006). Notes on the morphology of Tetrapedia diversipes Klug 1810 (Tetrapediini, Apidae), an oilcollecting bee. Brazilian Journal of Morphological Sciences, 23, 425-430.

Alves-dos-Santos, I., Machado, I. C., \& Gaglianone, M. C. (2007). História natural das abelhas coletoras de óleo. Oecologia Brasiliensis, 11 (4), 544-557. 
Baker, H. G., \& Hurd, P. D. (1968). Intrafloral ecology. Annual Review of Entomology, $13,385-414$.

Batra, S. W. (1984) Solitary Bees. Scientific American, 250(2), 86-93.

Borror, D. J., \& DeLong, D. M. (2005). Introduction to the study of insects. Ed. 7. Belmont: Thomson Brooks/Cole. 864p.

Bosch, J., \& Vicens, N. (2005). Sex allocation in the solitary bee Osmia cornuta: do females behave in agreement with Fisher's theory? Behavioral Ecology and Sociobiology, 59, 124-132.

Bosch, J. (2008). Production of undersized offspring in a solitary bee. Animal Behaviour, 75, 809-816.

Buchmann, S. L. (1987). The ecology of oil flowers and their bees. Ann. Rev. Ecol. Syst., 18, 343-369.

Camilo, E., Garófalo, C. A., \& Serrano, J. C. (1993). Hábitos de nidificação de Melitoma segmentaria, Centris collaris, Centris fuscata e Paratetrapedia gigantea (Hymenoptera, Anthophoridae). Revista Brasileira de Entomologia, 37, $145-156$.

Cane J. H., Eickwort, G. C., Wesley, F. R., Spielholz, J. (1983). Foraging, grooming and mate-seeking behaviors of Macropis nuda (Hymenoptera, Melittidae) and use of Lysimachia ciliata (Primulaceae) oils in larval provisions and cell linings. The American Midland Naturalist, 110, 257-264.

Cappellari, S. C., Melo, G. A., Aguiar, A. J., \& Neff, J. L. (2012). Floral oil collection by male Tetrapedia bees (Hymenoptera: Apidae: Tetrapediini). Apidologie, 43(1), 39-50.

Chiappa, E., \& Toro, H. (1994). Comportamiento reproductivo de Centris mixta tamarugalis (Hymenoptera: Anthophoridae). 2. Nidificacion y estados inmaduros. Revista Chilena de Entomología, 21, 99-115.

Cocucci, A. (1991). Pollination biology of Nierembergia (Solanaceae). Plant Systematics and Evolution, 174, 17-35.

Coville, R. E., G.W. Frankie, \& S. B. Vinson. (1983). Nests of Centris segregata (Hymenoptera, Anthophoridae) with a review of the nesting habits of the genus. Journal of Kansas Entomological Society, 56, 109-122.

Couto, R. M., \& Camillo, E. (2007). Influence of temperature on the immatures mortality of Centris (Heterocentris) analis (Hymenoptera, Apidae, Centridini). Iheringia. Série Zoologia, 97(1), 51-55. 
Fisher, R. A. (1958). The genetical theory of natural selection, 2nd ed. Dover, New York. 318p.

Gaglianone, M. C. (2001). Nidificação e forrageamento de Centris (Ptilotopus) scopipes Friese (Hymenoptera, Apidae). Revista Brasileira de Zoologia, 18(Supl 1), 107117.

Gaglianone, M. C., Aguiar, A. J. C. D., Vivallo, F., \& Alves-dos-Santos, I. (2011). Checklist of oil bees from São Paulo State, Brazil. Biota Neotropica, 11, 657666.

Gonçalves, R. B., \& Melo, G. A. (2005). A comunidade de abelhas (Hymenoptera, Apidae sl) em uma área restrita de campo natural no Parque Estadual de Vila Velha, Paraná: diversidade, fenologia e fontes florais de alimento. Revista Brasileira de Entomologia, 49(4), 557-571.

Gonçalves, R. B., Melo, G. A., \& Aguiar, A. J. (2009). A assembléia de abelhas (Hymenoptera, Apidae) de uma área restrita de campos naturais do Parque Estadual de Vila Velha, Paraná e comparações com áreas de campos e cerrado. Papéis Avulsos de Zoologia (São Paulo), 49(14), 163-181.

Jesus, B. M. V., \& Garofalo, C. (2000). Nesting behaviour of Centris (Heterocentris) analis (Fabricius) in southeastern Brazil (Hymenoptera, Apidae, Centridini). Apidologie, 31(4), 503-515.

Kuhlmann, M., \& Hollens, H. (2015). Morphology of oil-collecting pilosity of female Rediviva bees (Hymenoptera: Apoidea: Melittidae) reflects host plant use. Journal of Natural History, 49(9-10), 561-573.

Lasalle, J., \& Gauld, I. D. (1993). Hymenoptera and biodiversity. CAB International, Wallingford, 348p.

Luck, G. W., Daily, G. C., \& Ehrlich, P. R. (2003). Population diversity and ecosystem services. Trends in Ecology and Evolution, 18, 331-336.

Machado, I. C. (2004). Oil-collecting bees and related plants: a review of the studies in the last twenty years and case histories of plants occurring in NE Brazil. In: Freitas, B. M. \& Pereira, J. O. (eds) Solitary bees, conservation, rearing and management for pollination. Fortaleza, BR: Editora Universitária, 255-280.

Martins, C. F., Peixoto, M. P., \& Aguiar, C. M. (2014). Plastic nesting behavior of Centris (Centris) flavifrons (Hymenoptera: Apidae: Centridini) in an urban area. Apidologie, 45(2), 156-171. 
Martins, A. C., Melo, G. A. R., \& Renner, S. S. (2014). The corbiculate bees arose from New World oil-collecting bees: implications for the origin of pollen baskets. Molecular Phylogenetics and Evolution, 80, 88-94.

Martins, A. C., \& Melo, G. A. R. (2015). The New World oil-collecting bees Centris and Epicharis (Hymenoptera, Apidae): molecular phylogeny and biogeographic history. Zoologica Scripta, 1-12.

Martins, A. C., Melo, G. A., \& Renner, S. S. (2015). Gain and loss of specialization in two oil-bee lineages, Centris and Epicharis (Apidae). Evolution, 69(7), 18351844.

Melo, G. A. R., \& Gonçalves, R. B. (2005) Highter-level bee classifications (Hymenoptera, Apoidea, Apidae sensu lato). Revista Brasileira de Zoologia, 22 (1), 153-159.

Mendes, F. N., \& Rêgo, M. M. (2007). Nidificação de Centris (Hemisiella) tarsata Smith (Hymenoptera, Apidae, Centridini) em ninhos-armadilha no Nordeste do Maranhão, Brasil. Revista Brasileira de Entomologia, 51(3), 382-388.

Morato, E. F., \& Martins, R. P. (2006). An overview of proximate factors affecting the nesting behavior of solitary wasps and bees (Hymenoptera: Aculeata) in preexisting cavities in wood. Neotropical Entomology, 35(3), 285-298.

Michener, C. D. (1974). The Social Behavior of the Bees. Harvard University Press. Cambridge, Mass. 404 p. . (1981). Classification of the bee family Melittidae with a review of species of Meganomiinae. Contribution of the American Entomological Institute, 18: 1135.

. (2007). The Bees of the World. The Johns Hopkins Univ. Press, Baltimore. Maryland. 2nd ed. 953p.

Moure, J. S. (2002). Two new species of Centris Fabricius from Peru and notes on other two from São Paulo, Brazil, forgotten since their description (Hymenoptera, Apoidea, Anthophoridae). Revista Brasileira de Zoologia, 19, 159-166.

Moure, J. S. Melo, G. A. R. \& Vivallo, F. (2007). Centridini Cockerell \& Cockerell, 1901, in: Moure, J. S., Urban, D., \& Melo, G. A. R. Catalogue of Bees (Hymenoptera, Apoidea) in the Neotropical Region. Curitiba: Sociedade Brasileira de Entomologia. pp. 83-142. 
Neff, J. L., \& Simpson, B. B. (1981). Oil-collecting structures in the Anthophoridae (Hymenoptera): morphology, function, and use in systematics. Journal of the Kansas Entomological Society, 54 (1), 95-123.

Neto, S. S., Monteiro, R. C., Zucchi, R. A., \& Moraes, R. C. B. (1995). Uso da análise faunística de insetos na avaliação do impacto ambiental. Sci. agric., 52(1), 9-15.

Ramos, M., Mendes, F., Albuquerque, P., \& Rêgo, M. (2007). Nesting biology and foraging of Centris (Ptilotopus) maranhensis Ducke (Hymenoptera, Apidae, Centridini). Revista Brasileira de Zoologia, 24(4), 1006-1010.

Renner, S. S. (2006) Rewardless flowers in the Angiosperms and the role of insect congnition in their evolution, in: Waser, N. M., J. Ollerton (Eds.) Plantpollinator interactions, from specialization to generalization. The Univ. Chicago Press, 445p.

Renner, S. S. \& Schaefer, H. (2010). The evolution and loss of oil-offering flowers: new insights from dated phylogenies for angiosperms and bees. Philosophical Transactions of the Royal Society B: Biological Sciences, 365(1539), 423-435.

Roig-Alsina, A. (1997). A generic study of the bees of the tribe Tapinotaspidini, with notes on the evolution of their oil-collecting structures (Hymenoptera, Apidae). Mitteilungen der Münchner Entomologischen Gesellschaft, 87, 3-21.

Roubik, D. W. (1989) Ecology and Natural History of Tropical Bees. Cambridge Tropical Biology Series. Cambridge University Press, 513 p.

Rozen, J. G., \& Buchmann, S. L. (1990). Nesting biology and immature stages of the bees Centris caesalpiniae, C. pallida, and the cleptoparasite Ericrocis lata (Hymenoptera: Apoidea: Anthophoridae). American museum novitates (USA), 2985, 1-30.

Rupert, E. E., Fox, R.., \& Barnes, R. D. (2005). Zoologia dos Invertebrados: uma abordagem functional-evolutiva. 7 ed. São Paulo: Roca. 1145p.

Schlindwein, C. (2000). A importância de abelhas especializadas na polinização de plantas nativas e conservação do meio ambiente. Anais do Encontro sobre Abelhas (4): 131-141.

Schowalter, T. D. (2006). Insect ecology: an ecosystem approach. 2nd edn. Academic Press, San Diego. 572p. 
Silva, C. I., Queiroz, E. P., Faria, L. B. \& Alves-dos-Santos, I. (2012). Especialização na dieta de Centris (Paracentris) burgdorfi Friese, 1900 (Apidae, Centridini). Anais do X Encontro Sobre Abelhas. Ribeirão Preto: FUNPEC. 533p.

Silveira, F. A., Melo, G. A., \& Almeida, E. A. (2002). Abelhas brasileiras. Sistemática e Identificação. Fundação Araucária, Belo Horizonte.

Simpson, B. B., \& Neff, J. L. (1981) Floral Rewards: Alternatives to Pollen and Nectar. Annals of the Missouri Botanical Garden, 68, 301-322.

Simpson, B. B., Neff, J. L., \& Seigler, D. L. (1977). Krameria, free fatty acids and oil collecting bees. Nature, 267,150-151.

Simpson, B. B., Neff, J. L., \& Dieringer, G. (1990). The production of floral oils by Monttea (Scrophulariaceae) and the function of tarsal pads in Centris bees. Plant Systematics and Evolution, 173(3), 209-222.

Steiner, K. E., \& Whitehead, V. B. (1990). Pollinator adaptation to oil-secreting flowers - Rediviva and Diascia. Evolution, 44, 1701-1707. (1991). Oil flowers and oil bees: further evidence for pollinator adaptation. Evolution, 45, 1493-1501.

Strohm, E. \& Linsenmair, K. E. (1999). Measurement of parental investment and sex allocation in the European beewolf Philantus triangulum $\mathrm{F}$. (Hymenoptera: Sphecidae). Behavior Ecology and Sociobioly, 47, 76-88.

Taniguchi, M. (2010). Morfologia das estruturas envolvidas na coleta e transporte de óleo floral por fêmeas do gênero Centris (Hymenoptera, Apidae). Dissertação (Mestrado em Entomologia). Universidade de São Paulo, Ribeirão Preto.

Viana, B. F., \& Alves-dos-Santos, I. (2002). Bee diversity of the coastal sand dunes of Brazil. Pollinating bees: the conservation link between agriculture and nature. Ministry of Environment, Brasilia, 135-153.

Vinson, S. B., Williams, H. J., Frankie, G. W., \& Shrum, G. (1997). Floral lipid chemistry of Byrsonima crassifolia (Malpigheaceae) and a use of floral lipids by Centris bees (Hymenoptera: Apidae). Biotropica, 76-83.

Vivallo, F., \& Melo, G. A. R. (2010). Sistemática e fiologenia da tribo de abelhas Centridini e suas relações filogenéticas com as tribos cleptoparasitas Ericrocidini e Rhathymini. Anais do IX Encontro Sobre Abelhas. Ribeirão Preto: FUNPEC. $643 p$. 
Vivallo, F. (2014). Revision of the species of Centris (Xanthemisia) Moure, 1945 (Hymenoptera: Apidae: Centridini) from the Caribbean islands. Zootaxa (Auckland. Print), 3821: 58-70.

. (2015) State of the art and challenges of the taxonomy of the species of the tribe Centridini (Apidae: Apinae), in: Simões, Z. L. P., Almeida, J. M. J., \& Almeida, E. A. B. (Eds.), Anais do XI Encontro sobre Abelhas. Ribeirão Preto, pp. 99-100.

(2016). Taxonomic note on the oil-collecting bee Centris dimidiata (Olivier, 1789 (Hymenoptera: Apidae: Centridini). Zootaxa, 4162(3), 519. -534.

Vivallo, F., \& Vélez, D. (2016). A synopsis of the subgenus Centris (Hemisiella) Moure, 1945 (Hymenoptera: Apidae: Centridini) in Colombia, with description of a new species. Zootaxa, 4162(1), 107-133.

Vivallo, F., Vélez, D., \& Fernández, F. (2016). Two new species of Centris (Aphemisia) Ayala, 2002 from Colombia with a synopsis of the subgenus for the country (Hymenoptera: Apidae: Centridini). Zootaxa, 4093(2), 201-216.

Vogel, S. (1974). Ölblumen und ölsammelnde Bienen. Trop. Subtrop. Pflanzenwelt, 7 , 285-547. . (1976). Lysimachia: Ölblumen der Holarktis. Naturwissenschaften, 63: 44-45. . (1969). Flowers offering oil instead of nectar. XI Bot. Congr. Abstr. Seattle, Washington.

. (1981). Abdominal oil-mopping-a new type of foraging in bees. Naturwissenschaften, 67, 5627.

. (1984). The Diascia flower and its bee - an oil-based symbiosis in Southern Africa. Plant Biology, 33(4), 509-518.

Zanella, F. C. V. (2002). Sistemática, filogenia e distribuição geográfica das espécies sul-americanas de Centris (Paracentris) Cameron, 1903 e de Centris (Penthemisia) Moure, 1950, incluindo uma análise filogenética do "grupo Centris" sensu Ayala, 1998 (Hymenoptera, Apoidea, Centridini). Revista Brasileira de Entomologia, 46(4), 435-488. 
CAPÍİULO 1

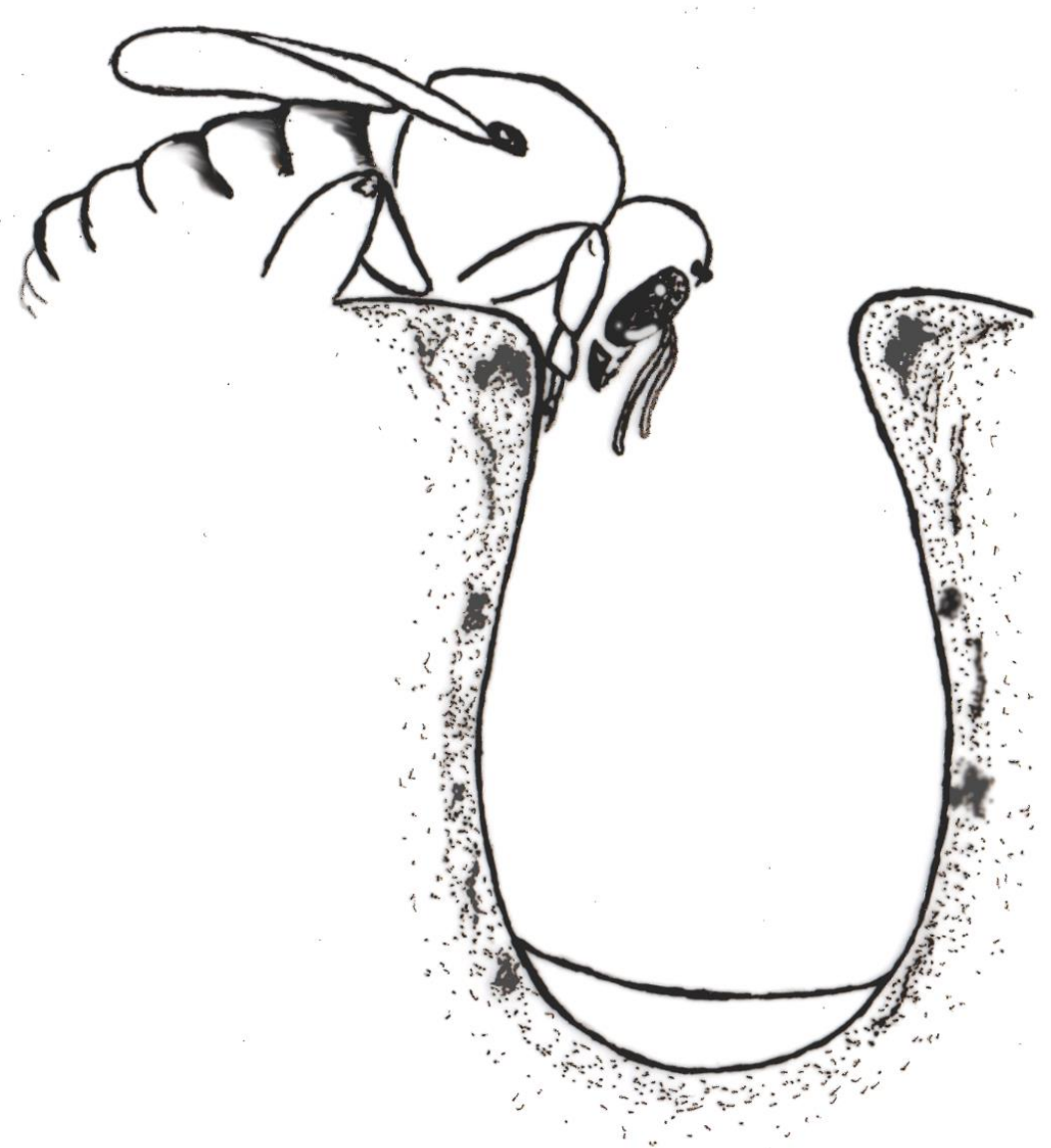




\title{
CHAPTER 1
}

Manuscript published in the Journal of Insect Behavior 30(1), 103-118.

\section{Mating System and Sleeping Behaviour of the Male and Female Centris (Paracentris) burgdorfi Friese (Apidae, Centridini)}

\section{William O. Sabino, Cláudia Inês da Silva and Isabel Alves-dos-Santos}

\author{
William O. Sabino*, Isabel Alves-dos-Santos \\ Departamento de Ecologia, Instituto de Biociências, Universidade de São Paulo, São Paulo, \\ Brasil \\ Cláudia I. Silva \\ Departamento de Zootecnia, Centro de Ciências Agrárias, Universidade Federal do Ceará, \\ Fortaleza, Ceará, Brasil \\ *Corresponding author. E-mail: sabinobees@gmail.com
}

\begin{abstract}
We describe the mating behaviour of males of Centris (Paracentris) burgdorfi, a solitary, univoltine bee, with a wide distribution in Brazil. We also describe the unusual sleeping sites of males and females. The study was performed during two breeding seasons, in northeastern Brazil, where the species nests in aggregations in petrified dunes. Data on mating behaviour were collected through direct observations of the bees at the nesting-emergence site. Males compete intensely for virgin females in the morning, sometimes killing rivals. The high competition for females near the nesting site makes that the male has to take the female to another place to get genital contact. In the evening, males do not use plants to spend the night, instead they aggregate in sleeping clusters inside old burrows in the nesting-emergence area while females sleep in groups on plants that provide the floral oil used in nest construction.
\end{abstract}

Key words Mating behaviour; oil-collecting bee; sexual selection; sleeping aggregation; solitary bee 
Resumo. Descrevemos o comportamento de acasalamento de machos de Centris (Paracentris) burgdorfi, uma abelha solitária, univoltina, com ampla distribuição no Brasil. Nós também descrevemos os locais não-usuais onde machos e fêmeas passam a noite. O estudo foi realizado em duas estações reprodutivas no Nordeste do Brasil, onde a espécie nidifica em agregações em dunas petrificadas. Os dados sobre o comportamento de acasalamento foram coletados através de observações diretas das abelhas no local de emergência. Os machos competem intensamente por fêmeas virgens na parte da manhã, às vezes matando rivais. A alta competição por fêmeas próximo ao local de nidificação faz com que os machos tenham que levar as fêmeas para outro local para conseguir o contato genital. À noite, os machos não usam plantas para passar a noite, ao invés disso, eles agregam-se em túneis antigos na área de nidificação, enquanto as fêmeas dormem em grupos em plantas que fornecem o óleo floral usado na construção do ninho.

Palavras-chave Abelha coletora de óleo; abelha solitária; comportamento de acasalamento; dormitórios; seleção sexual 


\section{Introduction}

Animal mating systems focus on the tactics used by individuals in sexually reproducing species (Kokko et al. 2014). Studies on mating systems have involved vertebrate (e.g., Orians 1969; Foltz 1981; Fleischer 1996; Mabry et al. 2013) and invertebrate animals (e.g., Bateman 1948; Miller and Tsao 1974; Eberhard 1991; Muniz and Machado 2015). The mating tactics of solitary bees, have also been described. In most cases, male solitary bees are easily observed, given their active behaviour and constant search for receptive female solitary bees (Paxton 2005). Male bees may search for virgin female bees in the emergence-nesting area (e.g., Hiller and Wittmann 1994; Ayasse et al. 2001), or they may patrol the flowering plants usually visited by resource-collecting females (e.g., Alves-dos-Santos 1999; Alcock et al. 2010). In addition, males of the same species may utilize alternative tactics, as in cases where large males fight for emerging females, whereas smaller males exhibit less aggressive tactics patrolling plants without any aggressiveness with other males (Alcock et al. 1977; Danforth 1991; Paxton 2005; Oliveira and Schlindwein 2010). Territorial males can also protect an emergence site or a particular group of plants and dig nests searching for females while males intruders try to take his place (e.g. Alcock et al. 1976). The evolution of alternative mating tactics is directly related to variation in the ability of males to secure access to receptive females (Alcock 2013).

Male bees are under selection to maximize their individual reproductive success in an environment in which receptive female bees are a limiting resource (Alcock et al. 1978), sometimes resulting in fighting among the males for mates. The intensity of sexual selection in male bees is generally related to the degree of rarity of female bees (Shuster 2009). Single mating by the females, which is a common behaviour for most solitary bees (Paxton 2005), promotes competition, since the number of sexually receptive females is lower than the number of sexually active males. The greater the number of mature males in relation to the number of receptive females, the higher the Operational Sex Ratio (OSR) and the stronger the competition among males (Ahnesjö et al. 2001). Generally, males emerge a few days before the females and rapidly start the search for receptive virgin females (Alves-dos-Santos 1999). This protandry means that even if the sex ratio is $1: 1$, according to Fisher (1958), the number of males capable of mating is much higher than the number of females, thereby generating strong competition among males. 
The hypothesis about the association between the spatiotemporal distribution of receptive females and the males' behaviour predicts that if the females nest aggregated the males will searching for receptive females at nest sites (Alcock et al. 1978; Ayasse et al. 2001; Paxton 2005). In dispersed nests, like bees that use pre-existing cavities, would become more difficult to find females, being more likely males searching for females in the flowers. Also, the high density of males would lead to a high competition between them while low density would stimulate the territoriality (Alcock et al. 1978; Ayasse et al. 2001; Paxton 2005).

The genus Centris Fabricius includes about 230 species of solitary bees found from Argentina to the southern United States (Moure et al. 2007). Identification can be difficult due to the complex taxonomy of the group (Vivallo and Zanella 2012). Many species of Centris collect floral oil, a resource used in feeding the larvae and in forming the cell lining (Vogel 1990). Although they are mostly abundant in the humid tropical areas, some species are found in semi-arid regions. The subgenus Centris (Paracentris) Cameron, for example, is most commonly represented in semi-desert Andean regions or in the semi-arid region of northeastern Brazil (Zanella 2002). Among the species found in this subgenus, Centris (Paracentris) burgdorfi Friese is a univoltine, protandric species, makes nest aggregated, widely distributed in Brazil and also occurring in some parts of Argentina and Paraguay (Zanella 2002). Females of Centris, like other solitary bees, frequently nest close to one another and sleep in these nests, whilst males sleep in the field, grouped under plants (Michener 2007).

Studies on the behaviour of Centris males have been carried out on some species, including $C$. crassipes Smith, $C$. dirrhoda Moure and C. fasciata Smith (Raw 1975), C. pallida Fox (Alcock 1976; Alcock et al. 1976; Alcock et al. 1977), C. adani Cockerell (Frankie et al. 1980), C. heithausi Snelling (Coville et al. 1986), C. lutea Friese and C. decolorata Lepeletier (Raw 1975; Alves-dos-Santos et al. 2009, cited as C. leprieuri Spinola), although more studies have addressed the nesting behaviour of females (e.g., Rozen and Buchman 1990; Aguiar and Gaglianone 2003; Rego et al. 2006; Ramos et al. 2007; Martins et al. 2013).

Although Centris genus has many species, our comprehension concerning to males' reproductive tactics or localities where both males and females spend the night is something scarce. Hence, here we address three important questions 1) What mating tactics are employed by the males of this species? 2) What is the daily activity pattern of males? 3) Where do males and females spend the night? Based on hypothesis about the 
association between the spatiotemporal distribution of receptive females and about male density we predict a high competition for females at nest sites.

\section{Material and Methods}

\section{Study Site}

Data on mating and sleeping behaviour of $C$. burgdorfi were collected from a touristic region known as 'Deserto dos Anjos' (053 $36^{\prime} \mathrm{S}, 35^{\circ} 14^{\prime} \mathrm{W}$; altitude: $41 \mathrm{~m}$ ), near the city of Natal, in Rio Grande do Norte state in northeastern Brazil. The region is located in a transition zone between areas that are hot and humid, due to high rainfall, and areas that are hot, but semi-arid due to strong evaporation (Nogueira 1982). The average annual temperature is $26.7^{\circ} \mathrm{C}$, with little variation throughout the year. The rainy season covers the period from March to August, with average annual rainfall of about $1640 \mathrm{~mm}$ (INMET/UFRN 2002).

Centris burgdorfi nests in geological formations, known as petrified dunes (Silva et al. 2012). These petrified dunes can form walls up to $50 \mathrm{~m}$ in height (Neto et al. 2005). These formations were produced at the edge of the sea when the current coastal plain was formed (Meireles and Santos 2012).

During the flight season of the bee, between April and July, the sun rises at 05:15 a.m. and sets at 05:30 p.m. Data on the behaviour of $C$. burgdorfi males were collected daily, between 04:30 a.m. and 05:30 p.m., in two breeding seasons, between April and May 2014 (247 h of observation in 19 days) and between May and June 2015 (208 $\mathrm{h}$ of observation in 16 days).

\section{Tactics for Finding Receptive Females}

In order to quantify the activity of the males, we counted for 12 days the number of males seen flying in the emergence-nesting area. The males were marked over thorax in the sleeping aggregation with different combinations of colours with a non-toxic paint pen (Posca ${ }^{\circledR}$ - Tokyo, Japan) in order to avoid count the same individual more than once. When there were fewer males at the site (about 30 individuals), males flew near the nest entrances with little interaction, allowing an accurate count of individuals. With increasing number of males, the bees constantly chased one another and so was difficult an accurate count. By the fact that the males fly uniformly on the aggregation was possible estimate the number of males flying. Using a fixed location in front of the 
aggregation, we count the number of males flying in a given area and estimate the number of males present in the rest of the nesting area. Even though this number does not represent the actual number of males present, it gives us an estimate of the total value at a particular time of day. The counting of the males was made every half an hour, covering the period just before the activity start to the time they were not observed in the aggregation. Using this methodology, it was possible to estimate the period when the activity of males searching for females was highest. The temperature was measured in front of the nesting site with a standardized digital thermo-hygrometer. We tested for an association between male activity and the temperature using a Spearman "two sided" rank-correlation test. Statistical analyses were made using Statistica 10.0.

\section{Male and Female Behaviour at Plants}

The species of plants used by the males and females were recorded, based on observations of the bees on the flowers and an analysis of the pollen collected from bee bodies or from bee nests (Sabino et al. in prep.). Using these methods, it was possible to know which plants males and females were visiting in the field being possible to monitor the behaviour of males in the plants.

\section{Mating behavior}

Copulations were videotaped and the behaviour of the males and females was recorded, as well as the time of copulation. The videos were later analysed to help describe the mating behaviour in a detailed fashion. To check for loss of attractiveness of mated females, a total of 20 females were marked on the thorax after the emergence and were observed throughout the nesting season.

\section{Sleeping Aggregations}

After finding groups of sleeping males and females, we marked individually bees at these locations with paint dots on the thorax to assess the fidelity of the bees to their sleeping sites. We count the number of individuals present in the place that they use as a dormitory. The numbers are presented by mean \pm standard error. 


\section{Results}

\section{Searching for Receptive Females}

Males searched for emerging females in the areas where females had nested in the previous year and only in the morning of sunny days. On rainy days, few males were seen searching inasmuch as most males looked for shelter in the same galleries of petrified dunes that they used as a dormitory. The period of highest activity of males was between 09:00 a.m. and 10:30 a.m. Male patrolling activity subsequently declined sharply and ended at noon. Despite the increasing in temperature throughout the morning (which reached a maximum of about $36^{\circ} \mathrm{C}$ at $12: 00$ p.m. (Fig. 1)) there is no correlation between male activity and temperature ( $\mathrm{rs}=0.19 ; p=0.48$ ).

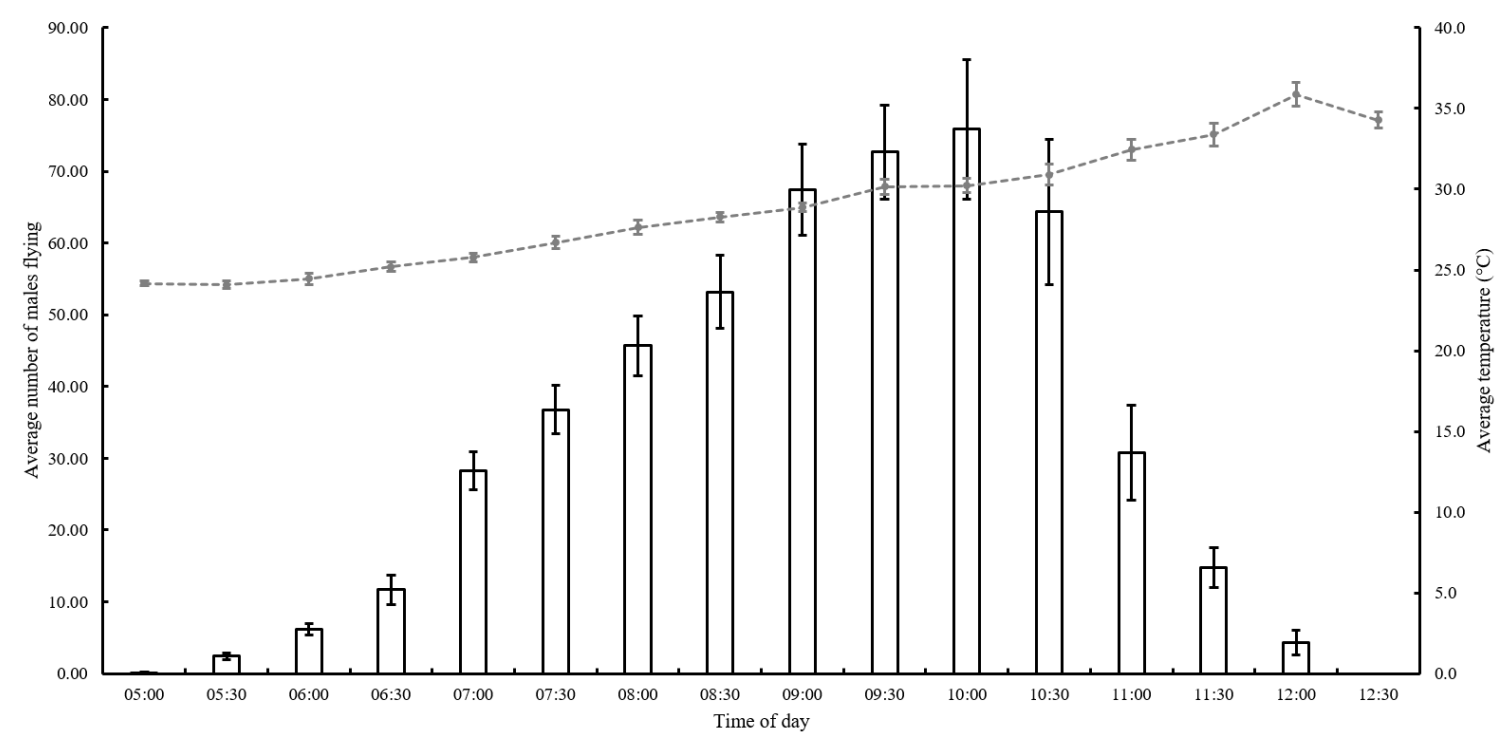

Fig. 1 Variation in the daily activity of Centris (Paracentris) burgdorfi males on patrol in the nesting area. The bars represent the average of males throughout twelve days with their standard errors. The dashed line represents the average temperature measured during the same period with standard errors

When relatively few males were present, individual bees attempted to control access to emergence holes by flying from one side of the tunnel entrance to the other, so as to prevent other males from stationing themselves around places from which emerging virgin females might appear. Territorial males sometimes collided with 
intruders or chased them some distance away. Occasionally, a territorial male and intruder might fall to the ground together. These fights sometimes ended in the death of one of the combatants by bites $(n=3)$.

At times, when males were not chasing or fighting with intruders, they covered the nest entrance with their legs, so as to control access to emerging females. Males stationed at emergence holes often lifted a leg and exposed the tibial spur to another male that had approached the spot (Fig. 2).

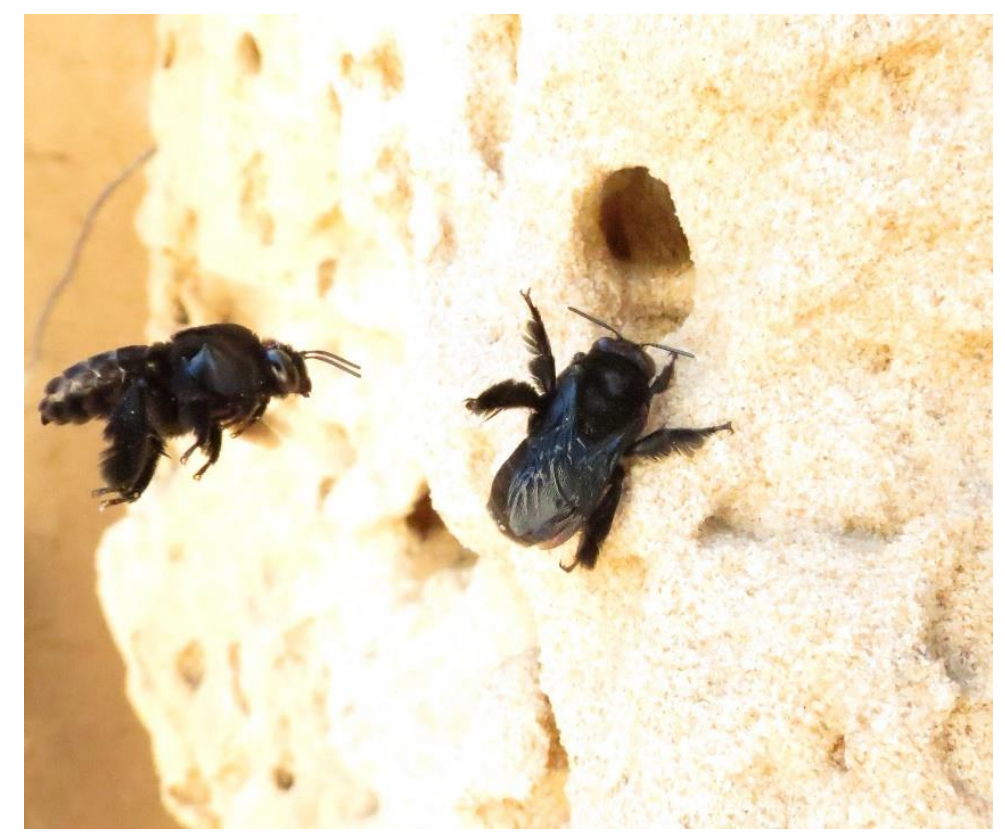

Fig. 2 Centris (Paracentris) burgdorfi male defending a tunnel in a petrified dune that was both a nest entrance and the potential exit for emerging virgin females. Notice that the perched male is using his left foreleg and midleg to ward off the intruder

On three occasions, we observed males digging into the petrified sand dune down to a cell that contained a virgin female and fighting for the spot with other males. On other occasions, the males were seen entering the emergence tunnels and subsequently mounting a female, with the pair flying off to copulate elsewhere $(n=2)$.

\section{Behaviour at Plants}

Males and females were observed collecting nectar on flowers of Stilpnopappus cearenses Huber (Asteraceae), Centrosema sp. (Fabaceae), and especially on flowers of 
Cuphea sp. (Lythraceae). We observed males $(\mathrm{n}=5)$ patrolling on Cuphea sp. flowers, searching for females. Each male had a small territory, which comprised only one plant. The males sometimes tried to control access to a small patch of flowers, chasing off competitors until only one male held the territory. The males' strategy in searching for females was compiled together with literature data about others Centris species (Table $1)$.

Table 1 Centris species classified according nest density and male behaviour

\begin{tabular}{|c|c|c|c|}
\hline Centris species & $\begin{array}{c}\text { Female (nest) } \\
\text { density }\end{array}$ & Male behaviour & References \\
\hline C. (Centris) adani & dispersed & Territoriality in food plants & Frankie et al. 1980 \\
\hline C. (Centris) decolorata & aggregated & Territoriality in the nesting site & $\begin{array}{l}\text { Raw 1974; Alves-dos- } \\
\text { Santos et al. } 2009\end{array}$ \\
\hline C. (Centris) dirrhoda & aggregated & Territoriality by landmarks & Raw 1974 \\
\hline C. (Centris) fasciata & dispersed & Territoriality in food plants & Raw 1974 \\
\hline C. (Hemisiella) crassipes & dispersed & Territoriality by landmarks & Raw 1974 \\
\hline C. (Paracentris) burgdorfi & aggregated & $\begin{array}{l}\text { Scramble competition in the nesting site } \\
\text { and territoriality in food plants }\end{array}$ & This work \\
\hline C. (Paracentris) pallida & aggregated & $\begin{array}{l}\text { Scramble competition in the nesting site } \\
\text { and territoriality in food plants }\end{array}$ & $\begin{array}{l}\text { Alcock 1976; Alcock et al. } \\
\text { 1976; Alcock et al. } 1977\end{array}$ \\
\hline C. (Trachina) heithausi & aggregated & Territoriality in food plants & Coville et al. 1986 \\
\hline
\end{tabular}

\section{Mating Behaviour}

When the female emerges, males crowd around her (Fig. 3a), but most do not achieve genital contact. Instead one male grasps the female and flies away with her, far from the other males. When the pair alight, as far as $200 \mathrm{~m}$ or more from the spot where the female emerged, copulation is completed in $6.99 \pm 0.31 \mathrm{~min}$; (mean $\pm \mathrm{SE} ; n=11$ ). During copulation, the male uses his front legs to immobilize the female and to support the pair on the substrate, while the middle legs prop up the midlegs of the female, so that she cannot support herself on the substrate. With his hind legs, the male immobilizes the female's wings and attempts to lift her abdomen in order to promote coupling. After genital coupling occurs, the male vibrates his wings continuously, producing a buzzing sound, while at the same time touching the female antennae 
repeatedly (Fig. 3b). During copulation, the male frequently interrupts genital contact in order to rub a hind leg against the female's abdomen.

Copulation may occur entirely in one place, usually a hard, flat surface. In situations where mating occurs on soft substrates, such as branches of plants or flowers, the male often carries the female to several locations, holding her body with his front and middle legs, while flying about $50 \mathrm{~cm}$ from the ground. Whenever the pair alight, the male attempts to make genital contact as the female holds onto the substrate (Fig. $3 c)$. The female appears to contribute to flight by flapping her wings.

After mating the female remains still for a few seconds before beginning a series of abdominal contractions, after which she rubs the inner part of her hind legs on her abdomen (Fig. 3d). Immediately after mating, the females become unattractive, such that even when other males approach mated females, they do not try to copulate. None of the females marked after mating and observed while nesting was ever seen copulating again. After copulation is completed, males return to the emergence area and compete again with other males for new females.

\section{Unusual Sleeping Aggregations}

Males spend the night in the vicinity of the nesting-emergence site, which they approach around 4:30 p.m. The resting place is at the highest part of the petrified dunes, which the first rays of sun reach at dawn. The first males to arrive occupy the various natural cavities, but are joined by other males to form groups in these places. Males that have been defending emergence tunnels arrive later, at around 05:30 p.m. We do not have the precise number of males inside de natural cavities, but the number of males outside was about $59.5 \pm 1.02$ ( $n=11$ days; Fig. 4$)$.

The female bees do not spend the night in the same locations as the males. Instead, they aggregate in flowers and fruits of Krameria tomentosa A. St. Hill (Krameriaceae) (Fig. 5a). The dormitory of the females is located approximately $160 \mathrm{~m}$ away from the nesting site. All females were marked for two successive nights (42 females in the first night and 34 in second), with different colours, and this technique showed that females always returned to the same plant (Fig. 5b). By examining several other plants in the area, we found that females use $K$. tomentosa exclusively when sleeping (ca. 15 females per branch). By marking the females at night and observing them the next day, we learned that the plants are used both by females that were already 
building nests, and by females that were still seeking a nest site (Fig. 5c). The females arrive at their resting sites at around 05:00 p.m. and leave at 05:15 a.m.

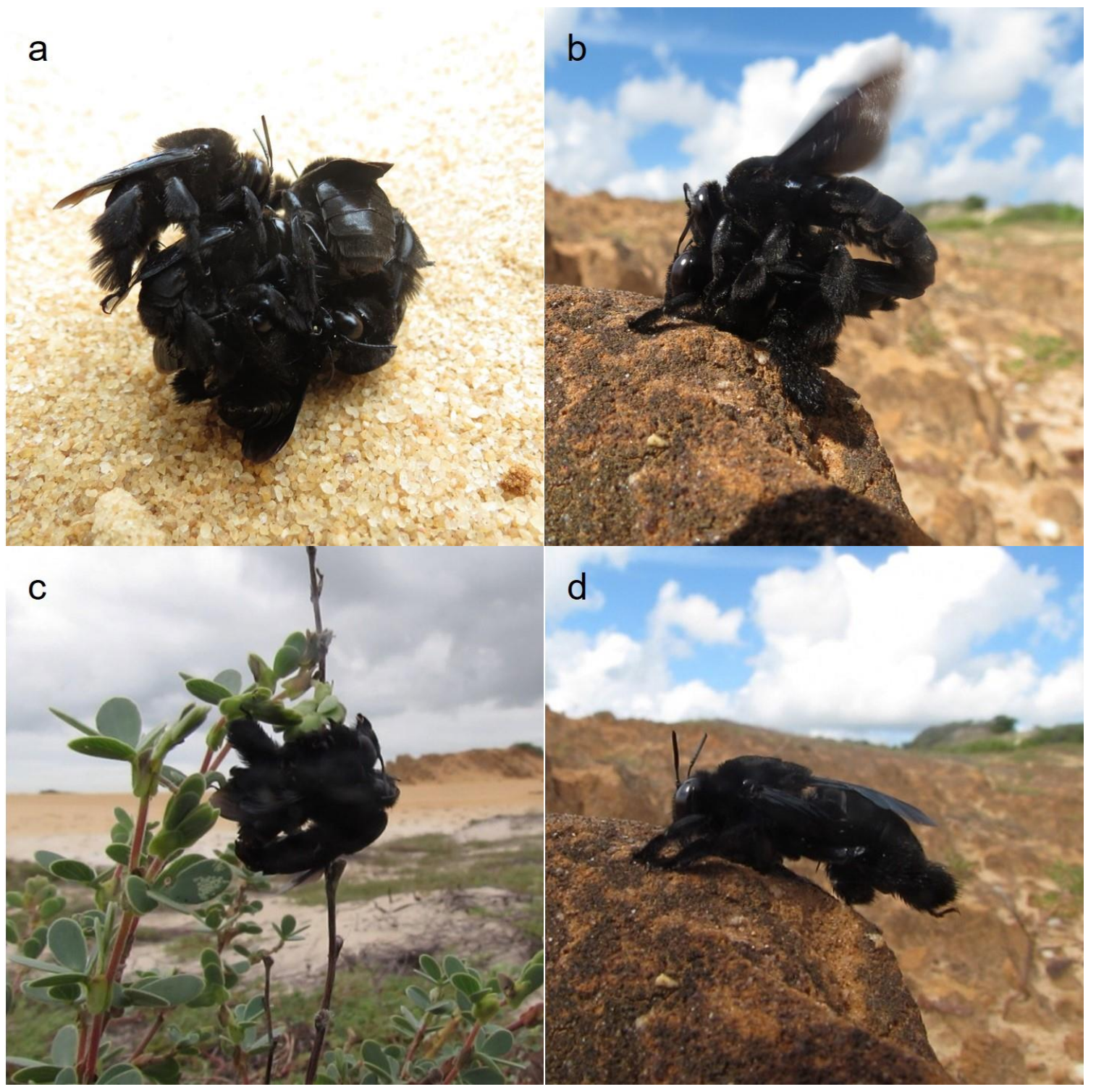

Fig. 3 Mating behaviour of Centris (Paracentris) burgdorfi. (a) Group of males around a female on the ground below the nest. (b) Male making genital contact with a female while vibrating his wings. (c) Mating on a plant branch in which the male is mounted on a female while the female holds the substrate. (d) Female beginning to use the inner part of her hindlegs to rub her abdomen shortly after mating 


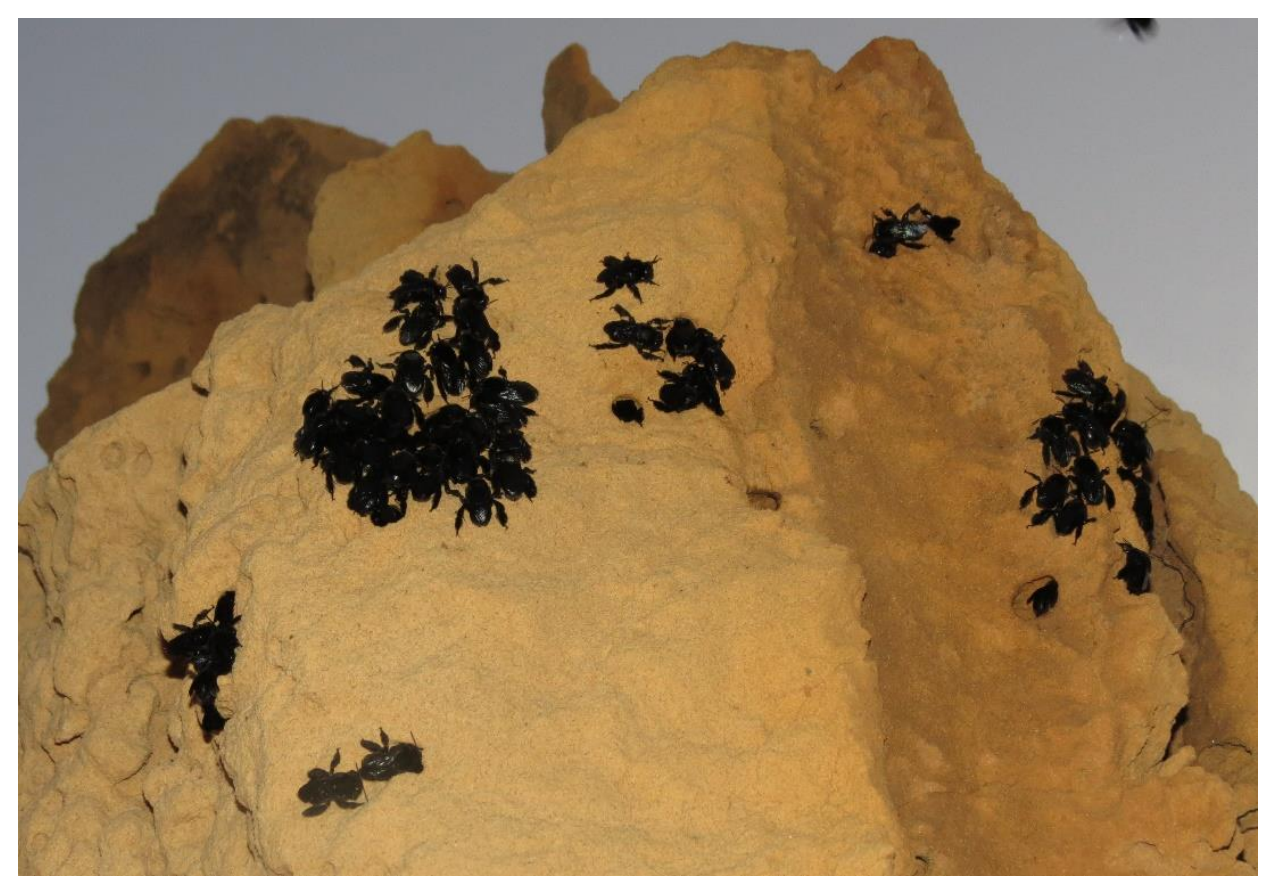

Fig. 4 Sleeping aggregation of Centris (Paracentris) burgdorfi males at the top of petrified dunes

The female bees do not spend the night in the same locations as the males. Instead, they aggregate in flowers and fruits of Krameria tomentosa A. St. Hill (Krameriaceae) (Fig. 5a). The dormitory of the females is located approximately $160 \mathrm{~m}$ away from the nesting site. All females were marked for two successive nights (42 females in the first night and 34 in second), with different colours, and this technique showed that females always returned to the same plant (Fig. 5b). By examining several other plants in the area, we found that females use $K$. tomentosa exclusively when sleeping (ca. 15 females per branch). By marking the females at night and observing them the next day, we learned that the plants are used both by females that were already building nests, and by females that were still seeking a nest site (Fig. 5c). The females arrive at their resting sites at around 05:00 p.m. and leave at 05:15 a.m. 


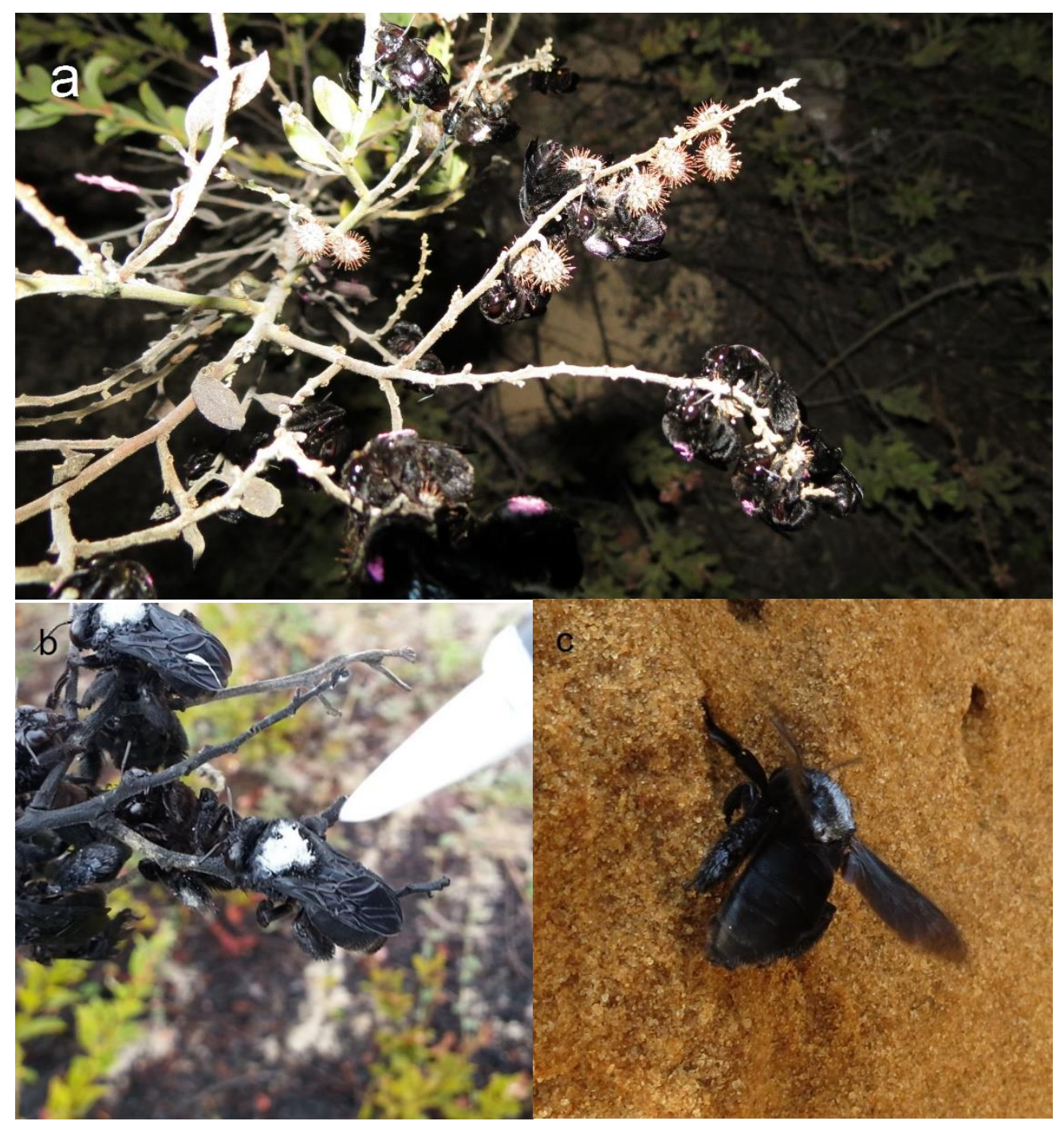

Fig. 5 Sleeping aggregation of Centris (Paracentris) burgdorfi females. (a) Group of females in branches of Krameria tomentosa at the end of the day. (b) Females marked on the late afternoon, as the sleeping aggregation forms. (c) A female marked at her sleeping site, returning to her nest in the morning

\section{Discussion}

\section{The alternative Mating Tactics}

Sexual selection has evidently resulted in males searching for females primarily during the period when potential matings are more likely to occur (Alcock 2013). Alves-dosSantos (1999) observed a decrease in in male patrolling in five species of Ancyloscelis Latreille (A. apiformis Fabricius, A. romeroi Holmberg, A. gigas Friese, A. turmalis 
Vachal and A. ursinus Haliday) in the afternoon, which was associated with a possible decrease in the production and supply of nectar in plants and in the emergence of virgin females. Frankie et al. (1980) also associated reduced territory defense in $C$. adani males around 11:00 a.m. with the low amount of nectar available on the site.

Both males and females of $C$. burgdorfi visit the same flowering plants, as is true for many other solitary bees. For example, males of Centris heithausi Snelling visit the same flowering trees as females (Coville et al. 1986). Alves-dos-Santos (1999) found males of Ancyloscelis apiformis A. romeroi, A. gigas, A. turmalis and A. ursinus visiting the same flowers that females used as a source of nectar. This behaviour was also verified in Centris scopipes Friese, in which males and females collected nectar on Memora pilgrim (Miers) Sandwith (Bignoniaceae) (Gaglianone 2001). The male choice of the same flowering plants that the females uses indicates that, in addition to nectar source, males sometimes can mate with receptive females at flowers.

In solitary bees, the males of some species generally search for virgin females about to emerge from the last breeding season's nests (Hiller and Wittmann 1994; Mayer and Miliczky 1998; Ayasse et al. 2001). But some males of certain species may also patrol

flowers where females forage preferentially (Villalobos and Shelly 1991; Alves-dos Santos 1999; Alcock et al. 2010; Alcock and Buchmann 2011). The existence of alternative mating tactics suggests that not all females are immediately 'caught' by males as soon as they emerge (Alcock et al. 2010). As the activity of $C$. burgdorfi males ceases late in the morning, females that emerge in the afternoon probably mate the next day, perhaps while foraging for nectar or pollen. Furthermore, some females may escape unmated from the emergence site while males are pursuing other females or males (Alcock 2013). In Amegilla dawsoni Rayment (Apidae) even though the high competition by males for females at the nesting site, some 10-20\% of females leave the emergence site unmated (Simmons 2015). In many Centris species we observed males making territories even when the females nest aggregated (Table 1). These males mark territories by depositing a scent from their mandibular glands into the vegetation (Raw 1975). Males of $C$. burgdorfi showed a high competition for females at nest sites as predicted by hypothesis about the association between the spatiotemporal distribution of receptive females and male density. The same occur in C. pallida in Sonoran Desert, USA (Alcock 1976). But both species also exhibit different strategies in searching for females. The occurrence of different mating tactics of males within one species reflects 
the ability of individuals to adopt alternative behaviours, depending on the environmental conditions that they encounter (Alcock 1979).

The capacity of males to find pre-emergent females has been observed in some solitary bees (e.g., Alcock et al. 1976; Bergström and Tengö 1978). In Centris pallida, the digging males are common in the peak period of observed matings, suggesting that this behaviour has been biologically/or genetically programmed to coincide with the preferred time of emergence of the females (Alcock et al. 1976). Cane and Tengö (1981) demonstrated that components produced in the mandibular glands of receptive females of Colletes cunicularis Linnaeus (Colletidae) attract males, which find females in their brood cells even before they emerge. This ability enables males to mate with females before other competitors can (Alcock et al. 1976; Alcock 1980). If the same might be find in $C$. burgdorfi, then, this ability should be particularly advantageous for those males with higher chemical perception than theirs competitors since it is an aggregate nesting environment with intense competition, and single-mating females.

\section{The Mating System of Centris burgdorfi}

As copulation in $C$. burgdorfi is relatively long, it would be difficult to maintain full genital contact and also provide the hind leg stroking of the female in locations with many competing males. Due to the risk of interference during mating, it may be adaptive for males to copulate far from other bees, as has been suggested for Centris pallida by Alcock and Buchmann (1985). Alcock and Buchmann (2011) noted the difficulty in identifying the copulating male in Habropoda pallida Timberlake (Apidae), because of the great number of males clustering around a single recently emerged female. In Epichars bicolor Smith (Apidae), mating balls also formed around freshly emerged females even though only a single male actually copulated with a given female (Rocha-Filho et al. 2009). There was no full genital contact between males and females of $C$. burgdorfi during the time that males were competing with one another for females on the ground.

The significance of rubbing the female's abdomen in C. burgdorfi is unknown, although it could be a form of copulatory courtship that induces the female to release anti attractant odours or it could be involved with the application of scents from the male that reduce the female's attractiveness. The change in the profile of the cuticular odour in post-mating females is known in solitary bees (Schiestl and Ayasse 2000; Paxton 2005; Simmons 2015) and this odour may even be transmitted to the female 
through the male, as recorded in Osmia rufa (Ayasse et al. 2001), Centris adani Cockerell (Frankie et al. 1980) and butterflies of the genus Heliconius Kluk (Gilbert 1976). The so-called 'anti-aphrodisiacs' is a method the male uses to ensure paternity in an extremely competitive environment (Ayasse et al. 2001). In solitary bees, it has been demonstrated that males are able to distinguish between the odours of receptive and non-receptive females (Frankie et al. 1980; Schiestl and Ayasse 2000). Chemical analyses are required to determine if the male of $C$. burgdorfi transmits some odour to the female or if he only induces the production of non-attractive compounds.

The pattern of wing movement, movement, antennal tapping, and the sound produced by males of $C$. burgdorfi occurred in all observed copulations. Copulatory courtship is very common in insects (Eberhard 1994) and a poor performance by a mating male may result in the rejection of his sperm by the female (Eberhard 1991). For example, males of the red flour beetle Tribolium castaneum Herbst rub the lateral edges of the females' elytra with their tarsi during copulation. In experiments realized by Edvardsson and Göran (2000) males without tarsi achieved a lower fertilization success than did males with unmanipulated legs. Vibrating signals seem to be common during the mating of solitary bees and wasps (Eickwort and Ginsberg 1980; Larsen et al. 1986). Vibrations are generated by rhythmic thoracic oscillations in the same manner that move the wings (Hrncir et al. 2006). In Amegilla dawsoni Simmons et al. (2000) also reported a similar sound produced by the male when interacting with the female during mating. Osmia rufa Linnaeus (Megachilidae) has a pre-mating behaviour and experiments have shown that the female has a preference for a male with a longer duration of pre-mating vibration, which can be indicative of his health and vigour (Conrad et al. 2010). There are also cases in which females produce sound (stridulate) to communicate to males the end of the copula, as in Nemka viduata (Mutillidae) (Tormos et al. 2010). According to the authors the stridulation of the female at the end of mating, as observed in $N$. viduata, possible could help the movement of sperm into the spermathecal. Nevertheless, in $C$. burgdorfi these movements also occurred between genital contact and we do not test the hypothesis that such moves would function as copulatory courtship or have another function.

\section{The Unusual Sleeping Behaviour}

The behaviour of $C$. burgdorfi males spending the night in places where the females nest is unusual among solitary bees. It is more common to observe males sleeping on 
branches of plants and flowers near the nesting area (Linsley 1962; Frankie et al. 1980; Alcock 1998; Alves-dos-Santos 1999; Wcislo 2003; Fraberger and Ayasse 2007). Field experiments conducted by Alcock (1998) demonstrated fidelity to the site where the males of Idiomelissodes duplocincta Cockerell (Apidae) slept. According to the author, one of the possible factors responsible for such behaviour could be an odour deposited in the place by the males to attract them the next night. This odour could also be one of the reasons why females do not use the galleries where males spend the night as a possible nesting site. The fact that $C$. burgdorfi males maintain a dormitory on the same site may enable males to gain quicker access to virgin females. The behaviour of entering the nests to take the females, with the associated antagonistic behavior between males for access to females, and the great number of males flying over the aggregation when most females emerge as adults may have favoured males that sleep near nesting aggregations formed in the preceding year.

The benefits for male Hymenoptera in sleeping in groups are not yet completely understood. Thermoregulation has been suggested by some authors (e.g., Evans and Gillaspy 1964), but sleeping aggregations have also been observed in places where temperatures remained high. For example, males of Idiomelissoides duplocincta form large sleeping aggregations even at high temperatures during the summer in Arizona (Alcock 1998), as is also true for C. burgdorfi in that the nesting site is subject to high temperatures in both the day and night. Another hypothesis is that this behaviour is beneficial for defence against predators, which could mean a survival advantage for individuals in a large group (Evans and Linsley 1960; Alcock 1998). This is also controversial as it has been shown in stingless bees that sleeping in aggregation exposes males to a greater risk of predation and parasitism (Brown 1997), precisely because of the density dependent effect. This topic should be studied further as there is probably no single explanation for the phenomenon.

The behaviour of females spending the night on flowers, and away from the nest is not common. When building new nests, Centris females often spend the night in the nesting cavity (e.g., Gaglianone 2001; Aguiar and Gaglianone 2003; Rego et al. 2006; Ramos et al. 2010) or in adjacent cavities that are unoccupied (e.g., Ramos et al. 2010).

Despite reports of nest guarding behaviour by females after the activity period, as seen in $C$. flavifrons Friese (Martins et al. 2013), the fact that the females of $C$. burgdorfi do not spend the night in the nest site does not necessarily mean an increased susceptibility of the nest under construction to cleptoparasitic attacks, since 
cleptoparasites tend to be more active during the day (Wcislo et al. 2004; Kelber et al. 2005). Future studies are required to understand the advantage of locating the dormitories away from the nests and from the brood. The only source of oil resources identified in nests of C. burgdorfi was Krameria tomentosa (Silva et al. 2012), the same plant where the females spend the night. The adaptive significance of females sleeping on $K$. tomentosa is unknown, although perhaps females that choose this plant can secure floral oils from it early in the morning, before returning to their nests. This should be tested to determine if this resource is limited in the area.

Centris burgdorfi was never found nesting in other sites besides petrified dunes in Brazil. The same structure is using as nesting place by the females and as sleeping place by the males. The presence of these geological formations in the environment is of extreme importance for the maintenance of these species that require this particular structure in their life cycles. The loss of habitat has been a decisive factor in the disappearance of several insect populations which, in turn, can affect many ecosystem services.

Acknowledgements The authors are grateful to Paulo Roberto de Castro for the help and all support in the field work and to Astrid Kleinert, Carlos A. Garófalo, Felipe Vivallo, Reisla Oliveira, Roberto Shimizu e Sheina Koffler for comments and suggestions in the manuscript and, especially, John Alcock for critical reading and valuable recommendations to the manuscript. We also thank to the two anonymous reviewers who helped to improve the manuscript. The research was supported by Fundação de Amparo à Pesquisa do Estado de São Paulo (FAPESP) and Conselho Nacional de Desenvolvimento Científico e Tecnológico (CNPq).

\section{References}

Aguiar CML, Gaglianone MC (2003) Nesting biology of Centris (Centris) aenea Lepeletier (Hymenoptera, Apidae, Centridini). Rev Bras Zool 20 (4): 601-606

Ahnesjö I, Kvarnemo C, Merilaita S (2001) Using potential reproductive rates to predict mating competition among individuals qualified to mate. Behav Ecol 12(4): 397401

Alcock J (1976) The social organization of male populations of Centris pallida (Hymenoptera, Anthophoridae). Psyche 83(2): 121-131 
(1979) The evolution of intraspecific diversity in male reproductive strategies in some bees and wasps. In: Blum MS, Blum NA (eds) Sexual selection and reproductive competition in insects. Academic Press, New York, pp 19-80 (1980) Natural selection and the mating systems of solitary bees. Am Sci 68(2): $146-153$ (1998) Sleeping aggregations of the bee Idiomelissodes duplocincta (Cockerell) (Hymenoptera: Anthophorini) and their possible function. J Kans Entomol Soc 71 (1): 74-84

(2013) Sexual selection and the mating behavior of solitary bees. Adv Stud Behav 45: 1-48

Alcock J, Buchmann SL (1985) The significance of post-insemination display by male Centris pallida (hymenoptera: Anthophoridae). Z Tierpsychol 68(3):231-243

Alcock J, Buchmann SL (2011) The mating system of Habropoda pallida Timberlake (Anthophorinae: Apidae). J Insect Behav 24:348-362

Alcock J, Jones CE, Buchmann SL (1976) Location before emergence of the female bee, Centris pallida, by its male (hymenoptera: Anthophoridae). J Zool 179(2):189-199

Alcock J, Jones CE, Buchmann SL (1977) Male mating strategies in the bee Centris pallida Fox (Anthophoridae: hymenoptera). Amer Nat 111:145-155

Alcock J, Barrows EN, Gordh G, Hubbard J, Kirkendall L, Pyle DW, Ponder TL, Zalom FG (1978) The ecology and evolution of male reproductive behaviour in the bees and wasps. Zool J Linnean Soc 64:293-326

Alcock J, Bailey WJ, Simmons LW (2010) The mating system of Amegilla (Asarapoda) paracalva brooks (hymenoptera: Apidae). J Insect Behav 23(1):69-79

Alves-dos-Santos I (1999) Aspectos morfológicos e comportamentais dos machos de Ancyloscelis Latreille (Hymenoptera, Apoidea). Rev Bras Zool 16(Suppl 2): 3743

Alves-dos-Santos I, Gaglianone MC, Naxara SRC, Engel MS (2009) Male sleeping aggregations of solitary oil-collecting bees in Brazil (Centridini, Tapinotaspidini, and Tetrapediini; Hymenoptera: Apidae). Genet Mol Res 8 (2): 515-524

Ayasse M, Paxton RJ, Tengo J (2001) Mating behavior and chemical communication in the order Hymenoptera. Ann Rev Ent 46:31-78

Bateman AJ (1948) Intra-sexual selection in Drosophila. Heredity 2(3):349-368 
Bergström O, Tengö J (1978) Linalool in mandibular gland secretion of Colletes bees (Hymenoptera: Apoidea). J Chem Ecol 4: 437-449

Brown BV (1997) Parasitic phorid flies: a previously unrecognized cost to aggregation behavior of male stingless bees. Biotropica 29 (3): 370-372

Cane JH, Tengö, JO (1981) Pheromonal cues direct mate-seeking behavior of male Colletes cunicularius (Hymenoptera: Colletidae). J Chem Ecol 7(2): 427-436

Conrad T, Paxton RJ, Barth FG, Francke W, Ayasse M (2010) Female choice in the red mason bee, Osmia rufa (L.) (Megachilidae). J Exp Biol 213: 4065-4073

Coville RE, Frankie GW, Buchmann SL, Vinson SB, Williams HJ (1986) Nesting and male behavior of Centris heithausi (Hymenoptera: Anthophoridae) in Costa Rica with chemical analysis of the hindleg glands of males. J Kans Entomol Soc 59 (2): $325-336$

Danforth BN (1991) The morphology and behavior of dimorphic males in Perdita portalis (Hymenoptera, Andrenidae). Behav Ecol Sociobiol 29: 235-247

Eberhard WG (1991). Copulatory courtship and cryptic female choice in insects. Biol Rev 66(1): 1-31

(1994) Evidence for widespread courtship during copulation in 131 species of insects and spiders, and implications for cryptic female choice. Evolution 48 (3): $711-733$

Edvardsson M, Göran A (2000). Copulatory courtship and cryptic female choice in red flour beetles Tribolium castaneum. P Roy Soc Lond B Bio 267(1443): 559-563

Eickwort GC, Ginsberg HS (1980) Foraging and mating behavior in Apoidea. Annu. Rev. Entomol 25: 421-446

Evans HE, Linsley EG (1960) Notes on a sleeping aggregation of solitary bees and wasps. Bull South Calif Acad Sci 59: 30-37

Evans HE, Gillaspy JE (1964) Observations on the ethology of digger wasps of the genus Steniolia (Hymenoptera: Sphecidae: Bembicini). Am midl nat 257-280

Fisher RA (1958) The genetical theory of natural selection, 2nd edn. Dover, New York, p 318

Fleischer RC (1996) Application of molecular methods to the assessment of genetic mating systems in vertebrates. In: Ferraris JD, Palumbi SR (eds) Molecular zoology. Advances, strategies and protocols. Wiley-Liss, New York, pp 133162 
Foltz DW (1981) Genetic evidence for long-term monogamy in a small rodent, Peromyscus polionotus. Am Nat 117(5):665-675

Fraberger RJ, Ayasse M (2007) Mating behavior, male territoriality and chemical communication in the European spiral-horned bees, Systropha planidens and $S$. curvicornis (hymenoptera: Halictidae). J Kans Entomol Soc 80(4):348-360

Frankie GW, Vinson SB, Coville RE (1980) Territorial behavior of Centris adani and its reproductive function in the costa Rican dry forest (hymenoptera: Anthophoridae). J Kans Entomol Soc 53(4):837-857

Gaglianone MC (2001) Nidificação e forrageamento de Centris (Ptilotopus) scopipes Friese (Hymenoptera, Apidae). Rev Bras Zool 18(Supl 1): 107-117

Gilbert LE (1976) Postmating female odor in Heliconius butterflies: a male-contributed antiaphrodisiac? Science 193:419-420

Hiller B, Wittmann D (1994) Seasonality, nesting biology and mating behavior of the oil-collecting bee Epicharis dejeanii (Anthophoridae, Centridini). Biociências 2(1): 107-124

Hrncir M, Schmidt VM, Schorkopf DLP, Jarau S, Zucchi R, Barth FG (2006) Vibrating the food receivers: a direct way of signal transmission in stingless bees (Melipona seminigra). J Comp Physiol A 192: 879-887.

INMET/UFRN (2002) Instituto Nacional de Meteorologia/UFRN. Boletins Climatológicos: anos 1984 a Maio/2002. Estação Climatológica Principal. Natal

Kelber A, Warrant EJ, Pfaff M, Walle'n R, Theobald JC, Wcislo WT, Raguso RA (2005) Light intensity limits foraging activity in nocturnal and crepuscular bees. Behav Ecol 63-72

Kokko H, Klug H, Jennions, MD (2014) Mating systems. In: Shuker DM, Simmons LW (eds) The Evolution of Insect Mating Systems, Oxford University Press, Oxford, pp 42-57

Larsen ON, Gleffe G, Tengö J (1986) Vibration and sound communication in solitary bees and wasps. Physiol entomol 11(3): 287-296

Linsley EG (1962) Sleeping aggregations of aculeate Hymenoptera-II. Ann Entomol Soc Am 55(2): 148-164

Mabry KE, Shelley EL, Davis KE, Blumstein DT, Van Vuren DH (2013) Social mating system and sex-biased dispersal in mammals and birds: a phylogenetic analysis. PLoS One 8(3):e57980 
Martins CF, Peixoto MP, Aguiar CML (2013) Plastic nesting behavior of Centris (Centris) flavifrons (Hymenoptera: Apidae: Centridini) in an urban area. Apidologie 1-16

Mayer DF, Miliczky ER (1998) Emergence, male behavior, and mating in the alkali bee, Nomia melanderi Cockerell (Hymenoptera: Halictidae). J Kans Entomol Soc 71: 61-68

Meireles AJA Santos AMF (2012) Atlas de Icapuí. 1 ed. Fortaleza, CE. Editora Fundação Brasil Cidadão. 160p

Michener CD (2007) The Bees of the World. The Johns Hopkins Univ. Press, Baltimore. Maryland. 2nd ed. 953p.

Moure JS, Melo GAR, Urban D (2007) Catalogue of bees (Hymenoptera, Apoidea) in the neotropical region. Sociedade Brasileira de Entomologia, Curitiba

Muniz DG, Machado G (2015) Experimental limitation of oviposition sites affects the mating system of an arachnid with resource defence polygyny. Anim Behav 109:23-31

Neto OF, Costa FAA, Severo RNF, Júnior OFS, Scudelari AC (2005) Estudo da dinâmica de Falésias do município de Tibau do Sul - RN. Anais do $11^{\circ}$ Congr. Brasil. Geologia de Engenharia e Ambiental. Florianópolis - SC

Nogueira AMB (1982) O Cenozóico continental da região de Natal-RN. CoI. Textos Acad. UFRN 2 (284): 1-117

Oliveira R, Schlindwein C (2010) Experimental demonstration of alternative mating tactics of male Ptilothrix fructifera (Hymenoptera, Apidae). Anim Behav 80(2): 241-247

Orians G (1969) On the evolution of mating systems in birds and mammals. Am Nat 103(934):589-603

Paxton RJ (2005) Male mating behaviour and mating systems of bees: an overview. Apidologie 36(2): 145-156

Ramos M, Mendes F, Albuquerque P, Rêgo M (2007) Nidificação e forrageamento de Centris (Ptilotopus) maranhensis Ducke (Hymenoptera, Apidae, Centridini). Rev Bras Zool 24 (4): 1006-1010

(2010) Nesting behavior of Centris (Hemisiella) vittata Lepeletier (Hymenoptera: Apidae) in an area of the cerrado in the northeast of the State of Maranhão, Brazil. Neotrop Entomol 39(3):379-383 
Raw A (1975) Territoriality and scent marking by Centris males (hymenoptera, Anthophoridae) in Jamaica. Behaviour 54(3):311-321

Rego MMC, Albuquerque PMC, Ramos MC, Carreira LM (2006) Aspectos da Biologia de Nidificação de Centris flavifrons (Friese) (Hymenoptera: Apidae, Centridini), um dos Principais Polinizadores do Murici (Byrsonima crassifolia L. Kunth, Malpighiaceae), no Maranhão. Neotrop Entomol 35(5):579-587

Rocha-Filho LC, Silva CI, Gaglianone MC, Augusto SC (2009) Nesting behavior and natural enemies of Epicharis (Epicharis) bicolor Smith 1854 (Hymenoptera Apidae). Trop Zool 21(2): 227-242

Rozen JG, Buchman SL (1990) Nesting biology and immature stages of the bees Centris caesalpiniae, C. pallida and the cleptoparasite Ericrocis lata (Hymenoptera: Apiodea: Anthophoridae). Am Mus Novit 2985: 1-30

Schiestl FP, Ayasse M (2000) Post-mating odour in females of the solitary bee, Andrena nigroaenea (Apoidea, Andrenidae), inhibits male mating behaviour. Behav Ecol Sociobiol 48:303-307

Shuster SM (2009) Sexual selection and mating systems. PNAS 106(Supplement 1): 10009-10016

Silva CI, Queiroz EP, Faria L B, Alves-dos-Santos I (2012) Especialização na dieta de Centris (Paracentris) burgdorfi Friese, 1900 (Apidae, Centridini). Anais do X Encontro Sobre Abelhas. Ribeirão Preto: FUNPEC. 533p

Simmons LW, Tomkins JL, Alcock J (2000) Can minor males of Dawson's burrowing bee, Amegilla dawsoni (Hymenoptera: Anthophorini) compensate for reduced access to virgin females through sperm competition? Behav Ecol 11: 319-325

Simmons LW (2015) Sexual signalling by females: do unmated females increase their signalling effort? Biol Lett 11(6): 20150298

Tormos J, Asís JD, Polidori C, Benéitez A, Storino G (2010) The mating behaviour of the velvet ant, Nemka viduata (hymenoptera: Mutillidae). J Insect Behav 23(2):117-127

Villalobos EM, Shelly TE (1991) Correlates of male mating success in two species of Anthidium bees (Hymenoptera: Megachilidae). Behav Ecol Sociobiol 29(1): 4753

Vivallo F, Zanella FCV (2012) A new species of Centris (Paracentris) Cameron, 1903 from northeastern Brazil, with a key for the Centris species of the Caatinga region (Hymenoptera: Apidae) Zootaxa, 3298: 1-16 
Vogel S (1990) History of the Malpighiaceae in the light of the pollination ecology. Mem N Y Bot Gard 55: 130-142

Wcislo WT (2003) A male sleeping roost of a sweat bee, Augochlorella neglectula (Ckll.) (Hymenoptera: Halictidae), in Panamá. J Kans Entomol Soc.76: 55-59

Wcislo WT, Arneson L, Roesch K, Gonzalez V, Smith A, Fernández H (2004) The evolution of nocturnal behaviour in sweat bees, Megalopta genalis and $M$. ecuadoria (Hymenoptera: Halictidae): an escape from competitors and enemies? Biol J Linnean Soc 83: 377-387

Zanella FCV (2002) Sistemática, filogenia e distribuição geográfica das espécies sulamericanas de Centris (Paracentris) Cameron, 1903 e de Centris (Penthemisia) Moure, 1950, incluindo uma análise filogenética do "grupo Centris" sensu Ayala, 1998 (Hymenoptera, Apoidea, Centridini). Rev Bras Zool 46: 435-488 
อAPIITOLO 2

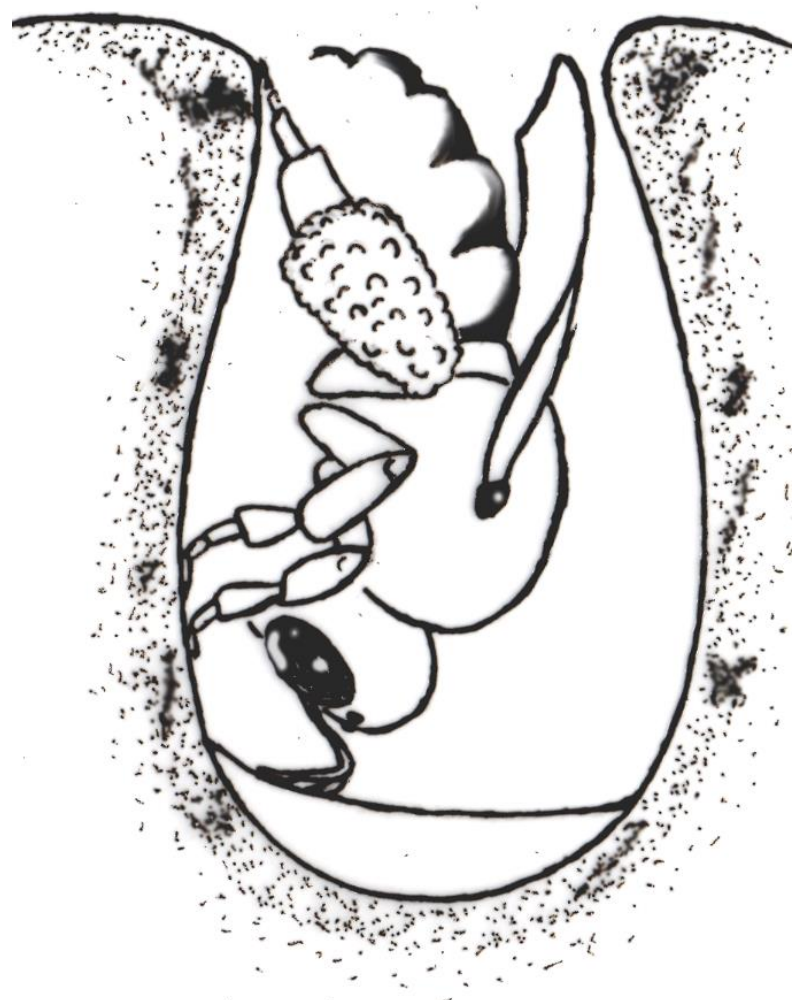




\title{
CHAPTER 2
}

\section{Manuscript formated to be submitted in the The Science of Nature (Naturwissenschaften)}

\section{Nesting biology of the bees Centris (Paracentris) burgdorfi Friese and Centris (Paracentris) pallida Fox (Apidae: Centridini)}

\author{
William O. Sabino ${ }^{1}$. Isabel Alves-dos-Santos ${ }^{1}$. Elisa Pereira Queiroz ${ }^{1}$. Letícia \\ Biral de Faria ${ }^{1}$. Daniel Papaj ${ }^{2}$. Stephen L. Buchmannn ${ }^{2}{ }^{3}$. Cláudia Inês da Silva ${ }^{1}$
}

1. Departamento de Ecologia, Instituto de Biociências, Universidade de São Paulo, São Paulo, SP 05508-900, Brazil; 2. Department of Ecology and Evolutionary Biology, University of Arizona, Tucson, AZ 85721, USA; 3. Department of Entomology, University of Arizona, Tucson, AZ 85721, USA.

\begin{abstract}
We described the nesting biology of Centris (Paracentris) burgdorfi, a solitary, univoltine bee that nests in petrified dunes in northeast Brazil. We present additional data on the nesting biology of Centris (Paracentris) pallida, that nests on the ground in the Sonoran Desert in the United States. We examined female activity patterns and nest construction. Most of the nest excavations of both species occurred in the morning, which may be related to high local temperatures and decreasing floral resources in the afternoon. Females of $C$. burgdorfi made 1 to 7 cells per nest with each cell requiring $2.62 \pm 0.40(\mathrm{n}=20)$ days to construct while $C$. pallida females usually built only one cell per nest (sometimes two) and spent $2.43 \pm 0.56(\mathrm{n}=15)$ days constructing each cell. The average cell construction times for these species are high when compared to other Centris studies. The temperature inside the C. burgdorfi nests is lower when compared to the ambient temperature but the same do not occur in $C$. pallida and this could be related with the nesting habitus of both species. The current knowledge of nesting biology within the subgenus Paracentris is sparse and our work contributes to a better understanding of the nesting biology of Centris bees.
\end{abstract}

Keywords: foraging behavior . oil-collecting bees . sexual ratio . solitary bees 
Resumo Nós descrevemos a biologia de nidificação de Centris (Paracentris) burgdorfi, uma abelha solitária, univoltina, que nidifica em dunas petrificadas no nordeste brasileiro. Apresentamos, também, dados adicionais sobre a biologia de nidificação de Centris (Paracentris) pallida, que nidifica no solo no deserto de Sonora, nos Estados Unidos. Foram examinados os padrões de atividade das fêmeas e a construção do ninho. A maioria das escavações de ninho de ambas as espécies ocorreu na parte da manhã, o que pode estar relacionado com altas temperaturas locais e recursos florais decrescentes na parte da tarde. As fêmeas de $C$. burgdorfi produziram de 1 a 7 células por ninho, sendo que cada célula necessitou de 2,62 \pm 0,40 $(\mathrm{n}=20)$ dias para ser construída enquanto que as fêmeas $C$. pallida geralmente construíam apenas uma célula por ninho (às vezes duas) e gastaram $2,43 \pm 0,56(\mathrm{n}=15)$ dias construindo cada célula. Os tempos médios de construção de células para estas espécies são elevados quando comparados com outros estudos Centris. A temperatura dentro dos ninhos de C. burgdorfi é menor quando comparada com a temperatura ambiente, mas a mesma não ocorre em $C$. pallida, podendo estar relacionada com o habitus de nidificação de ambas as espécies. $\mathrm{O}$ conhecimento atual da biologia de nidificação no subgênero Paracentris é escasso e nosso trabalho contribui para uma melhor compreensão da biologia de nidificação de abelhas Centris.

Palavras-chave: abelhas coletoras de óleo . abelhas solitárias . comportamento de forrageamento . razão sexual 


\section{Introduction}

Many bees within the Centridini are known as oil-collecting bees, because females use floral oils as resources in cell construction and feeding their larvae (Vogel 1974; Buchmann 1987). The genus Centris Fabricius comprises a large number of solitary bee species distributed from Argentina to Mexico and the southwestern United States. Centris is a genus with a complex phylogeny. Roughly 250 valid species are grouped into 12 subgenera, but only Centris (Wagenknechtia) has been revised recently (Vivallo 2015). Although these bees are more abundant in the humid tropics, some taxa occur in temperate semiarid regions (Zanella 2002). The subgenus Centris (Paracentris) Cameron is more common in semi-arid regions, such as the Sonoran Desert of northern Mexico and the southwestern regions of Arizona and California in the United States (Alcock et al. 1976; Rozen and Buchmann 1990), Andean regions or semiarid region of northeastern Brazil (Zanella 2002; Vivallo e Zanella 2012).

All species of oil-collecting bees are solitary, but may or may not form nesting aggregations alongside other females. Centridine bees are important pollinators of wild and cultivated species (Freitas and Paxton 1998; Oliveira and Schlindwein 2009) and some plants (e.g. Malpighia, Byrsonima) depend exclusively on the pollination services of Centris bees because of their specialized oil-foraging behavior (Aguiar 2003).

Despite the Centridine being known for oil-collecting bees, some species have lost this behavior. The loss of the oil-collecting apparatuses, as seen in Centris (Paracentris) pallida Fox, and consequently non-dependence of floral oils, occurred independently at least twice in Centris (Neff and Simpson 1981; Martins and Melo 2015). The females of $C$. pallida seem to line the cells with glandular secretion make cells that are not waterproofed with resin or oil, but seem to be lined with a glandular secretion (Rozen and Buchmann 1990).

In Brazil, the most studied Centris species are those that nest in pre-existing cavities, especially in the drilled holes of wooden trap nests (Garófalo et al. 1989). Studies of ground-nesting species are less common (Aguiar and Gaglianone 2003; Rego et al. 2006). In Paracentris, besides $C$. pallida, there are studies of only 5 species (out of 59): C. nigerrima Spinola (Janvier 1926) in Chile, C. autrani Vachal (probably $C$. neffi Moure) in Bolivia (Janvier 1955), C. rhodopus Cockerell, C. cockerelli Cockerell, and C. caesalpiniae Cockerell (Rozen and Buchmann 1990) conducted in Arizona, USA. In Brazil, Silva et al. (2012) found a nesting aggregation of Centris (Paracentris) 
burgdorfi Friese, in northeastern Natal, state of Rio Grande do Norte (RN), Brazil. This species is widely distributed, occurring in other states within the northeastern region of central and south Brazil (Silveira et al 2002; Zanella 2002), but no nesting site for $C$. burgdorfi has ever been found until the present study.

This study investigates the nesting biology $C$. burgdorfi in a dunes region in Brazil and C. pallida in the Sonoran Desert in USA. To our knowledge, there is no information about the nesting behavior of $C$. burgdorfi. We evaluate the species' period of activity and construction of nests. We addressed the following questions: 1) How many nests does each female provision in her lifetime and how many cells do these nests contain? 2) How much time do females spend in nest and cell construction? 3) How long are foraging trips for nectar, pollen and oil? 4) How long do females spend manipulating these resources? 5) What is the seasonal emergence of the adult bees? 6) Is $C$. burgdorfi protandric with males emerging first? 7) What are the parasites of this species? 8) Are there morphological differences between males and females in cell size, shape or amount of provisions?

For $C$. pallida, we presented some additional nesting biology information. Knowing the high temperatures of the Sonoran Desert during the nesting period, we evaluated the temperature on the ground and compare with the ambient temperature. Additionally, we evaluate the period where the nesting peak occurs and the how long the female spend for a cell construction.

\section{Materials and Methods}

\section{Centris burgdorfi nest behavior}

We located a nesting aggregation of $C$. burgdorfi in a dunes region close to the city of Natal, RN, Northeast of Brazil (05³6.310'S, $35^{\circ} 14.435^{\prime} \mathrm{W}$; elevation: $\left.41 \mathrm{~m}\right)$. The average temperature is around $26.7{ }^{\circ} \mathrm{C}$ and the rainy season is from March to August, with an average annual rainfall of $1643.48 \mathrm{~mm}$ (INMET / UFRN 2002).

The behavior of foraging and nesting females was observed during two breeding seasons, between April and May 2014 (247 hours of observations), and between May and June 2015 (208 hours of observations). The field work was conducted daily from $0430 \mathrm{~h}$ to $1730 \mathrm{~h}$. In this location at this time of year, the sun rises at $0515 \mathrm{~h}$ and sets at $1730 \mathrm{~h}$ 
The C. burgdorfi females built nests in a formation of petrified sand dunes. These sandstones are sharp discontinuities in the ground surface, forming slopes reaching 50 meters high (Neto et al. 2005) with an approximate age between the upper Pleistocene and the Holocene (Nogueira 1981).

\section{Nest architecture and adult emergence}

Measurements were made of nest entrances and the lateral tunnels leading to natal cells. Some nests were excavated completely and returned to the laboratory in April 2011, February 2012 and April 2014 for analysis. Bee cells were separated and maintained in an incubator at the same internal temperature (about $28{ }^{\circ} \mathrm{C}$ ) as found within the nests. After all bees had emerged, their sex ratios and parasitism rates were determined. To test the hypothesis of the relationship between the sexes and the size of the cells, intertegular distance for 25 males and 25 females was measured (Cane 1987). We used 50 cells of each sex to measure the height of the cells and the diameter of the the widest point (base) and opening. All measurements were performed with a digital caliper (Digimess- 100.174BL).

We placed 10 cells completely wrapped in a well-moistened paper inside a vial for $24 \mathrm{~h}$. The objective was simulate a moist soil, to observe the water retardant nature and resistance of the cell walls material.

\section{Nesting activity of females}

A total of 20 females that initiated nest excavations were selected for monitoring of nesting behavior throughout the day (12 females in 2014 and 8 females in 2015). To identify individuals, females were captured and marked on their thoracic dorsum with different colors combinations made with non-toxic paint pen (Posca®; Tokyo, Japan). We were able to quantify the number of cells that each female constructed, as well as the foraging time and the time required to complete the construction of a cell and a nest. We discriminated between floral oil and pollen-collecting trips. Thus, it was possible to quantify the average time spent on oil-collection trips, lining the cells with oil, and the average duration of pollen-collecting trips, and the time females required to close their cells. Based on these data, the total duration of cell construction times was obtained, allowing comparisons of the time spent on each activity (Martins et al. 2014).

We made a small hole in the lateral part of the nest to monitor female activity. The orifice was small enough (about $1.5 \mathrm{~cm}$ ) to avoid interference in the behavior of the 
females, and the observation was made only in the absence of the female. After a quick inspection, inside of the nest the hole was sealed again with the same surrounding material.

Another five nests were selected to record in detail the construction activity, cell orientation and nature of the cell closures (operculae). We filmed the behavior of the nesting females and later analyzed and timed these behaviors in greater detail. These nests were not used for daily monitoring because, for recording, a larger hole at the top of the nest was necessary (about $3 \mathrm{~cm}$ in diameter) and, inevitably, the female left the nest after this disturbance was made.

To evaluate the geographical dispersion of nests across the petrified dunes we calculated a dispersion index. The total area was divided into $1 \mathrm{~m}^{2}$ quadrats (as proposed by Martins et al. 2014) and all the active nests inside this area were counted. The dispersion index ( $\mathrm{I}=$ variance/mean) was evaluated as follows: a random pattern: $\mathrm{s}^{2}=\bar{X}$; a grouped pattern: $\mathrm{s}^{2}>\bar{X}$ and a uniform pattern: $\mathrm{s}^{2}<\bar{X}$.

Temperature data both inside and outside the nests was measured with a standardized digital thermo-hygrometer (Instrutemp-ITHT 2250). The external and internal temperature of the nests was measured every 30 minutes (from $0530 \mathrm{~h}$ to 1730 h) for 12 days. Nests chosen for measurement were selected randomly every day, at different heights in the sandstone (lower positions near the ground, and the average middle height and the top of aggregation) to avoid a bias in the analyses. The outside ambient temperatures were taken always one meter in front of the same nest that the internal temperature was measure.

We also observed the presence of natural enemies, such as cleptoparasitic bees, parasitic wasp and bee fly and their behavior in the vicinity of the Centris aggregation.

\section{Centris pallida nests}

The Sonoran Desert extends from the northern end of the Gulf of California into the western half of Sonora, Mexico, southwestern Arizona, southeastern California, and Baja California (Turner and Brown 1982). The study was conducted primarily on Tumamoc Hill (T. Hill), which comprises 352 ha of Sonora Desert vegetation on land belonging to the State of Arizona ( $32^{\circ} 13.267^{\prime} \mathrm{N}$; $111^{\circ} 00.655^{\prime} \mathrm{W}$; elevation: $\left.724 \mathrm{~m}\right)$. This hill is an outlier of the Tucson Mountains, Pima County, Arizona, USA, and is situated west of downtown Tucson (Bowers 2005). 
Centris pallida nests on the ground, in open areas, usually in large aggregations (Alcock et al. 1976; Rozen and Buchmann 1990). The specie is more active in spring season (April/May) following the bloom of Parkinsonia species, where the female collect pollen and nectar (Alcock et al. 1976; Rozen and Buchmann 1990).

Data were collected between March and May 2016 during the entire breeding season (a total of 147 hours of observations). When a nest was found, we marked the entrance with a flag and waited until the female finished it. Only nests where we saw the female beginning the excavation were used to estimate how many days the females spent to build each cell. We measured the access tunnel and the depth of the cell in the soil with a ruler. The results are shown as mean \pm standard error.

To compare the temperature inside and outside the nests we used a data logger (Supco SL500TC) in the $C$. pallida nesting site $10 \mathrm{~cm}$ deep on the ground. The depth was chosen to simulate the temperature at the same level that the females of $C$. pallida build the cells. The data logger measured the temperature at the nesting site during $24 \mathrm{~h}$ for 33 days. The temperature outside the nests was provided by Dr. Larry Venable (EEB department, University of Arizona). The data are from the long-term plots in the creosote bush flats with the weather station very close to where we studied C. pallida nests.

\section{Data analysis}

A student $\mathrm{t}$ test was used to evaluate the sizes of males versus females as well as possible morphological differences between male and female cells.

A Chi-square test was used to assess if the proportion of males and females that emerged in laboratory differed from a 1:1 Fisherian sex ratio.

A Kruskal-Wallis test with Dunn post hoc test was used to evaluate the three main activities of the female in the construction of a cell (oil to lining, pollen to provision and oil for operculation/feeding larva) and the duration of each these activities inside the nest. A Mann-Whitney $U$ test was used to compare the duration of pollencollection trips with that of oil-collection trips used for both larval food provisioning and forming the cell closures (operculation). We used an ANOVA with Tukey post hoc test to evaluate the mean number of trips for oil collection for cell lining, for pollen collection, and for oil collection

A paired $t$ test was used to evaluate differences in the average temperatures of the external environment and the temperature inside the nest both for $C$. burgdorfi and 
C. pallida nests. Statistical analyses were performed using Statistica 7.0 software, based on Zar (1996) and Sokal and Rohlf (1995).

\section{Results}

\section{Nesting behavior of Centris burgdorfi}

\section{Architecture of the nests and emergence of individuals}

Female bees built their nests in the petrified dunes. No nests were observed in the loose sand (mobile dunes). Females excavate horizontal tunnels with small circular entrance holes $1.17 \mathrm{~cm} \pm 1.05(\mathrm{n}=134)$ diameter followed by a relatively straight tunnel of 5.60 $\pm 0.96 \mathrm{~cm}$ in length. Immediately after digging the nest burrow the female built linearly aligned cells adjacent to each other (Fig. 1a-b).

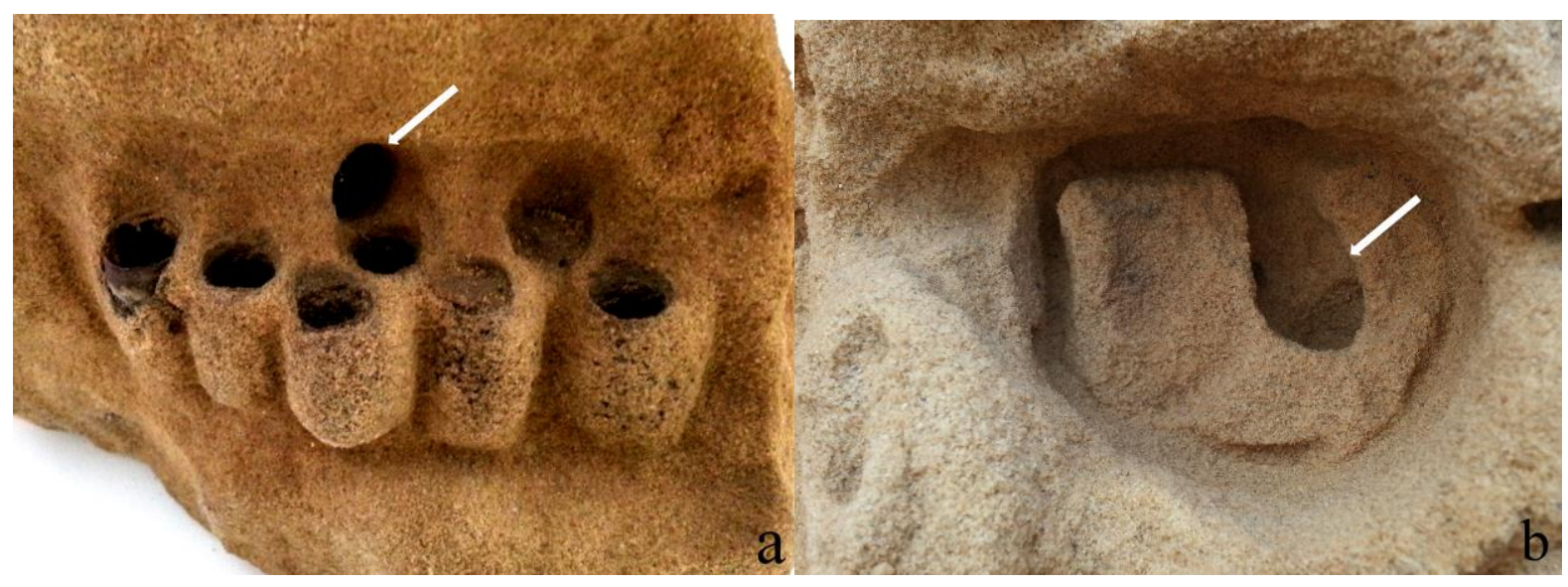

Fig. 1 A Centris burgdorfi nest in the sandstone substrate in northeast, Brazil, showing (a) the clumped arrangement of seven cells constructed by the female with the access tunnel (arrow) and (b) a cross section of a cell under construction, showing the cavity excavated by the female (arrow) that would subsequently be lined with oil

The emergence period was from March to July 2011, and from March to August in 2012. Of all cells collected in the field $(n=125), 62.4 \%$ had adults emerge, while $37.6 \%$ did not, a relatively high level of natal mortality. The observed male:female sex ratio of 0.825 did not differ statistically from a $1: 1$ sex ratio $\left(\chi^{2}=0.67, p=0.48 ; 33\right.$ males and 40 females). Centris burgdorfi is protandric, since in all observed nests, males emerged earlier than females. 
Females are bigger than males $\left(\mathrm{t}_{0.05 ; 48}=2.04, \mathrm{p}<0.05\right.$; Fig. $\left.2 \mathrm{a}\right)$ and this is reflected in the size of respective cells. Male-destined cells had an average height of $2.12 \mathrm{~cm} \pm 0.13(\mathrm{n}=50)$ while those of females were $2.19 \mathrm{~cm} \pm 0.14$ in height $(\mathrm{n}=50)$. This difference was significant $\left(\mathrm{t}_{0.05} ; 98=2.79 ; \mathrm{p}<0.05\right.$; Figure $\left.2 \mathrm{~b}\right)$. The same sexual dimorphism was observed in the size of the opening (spiral pattern cell closure), with male cells averaging $0.78 \mathrm{~cm} \pm 0.1$ in diameter $(\mathrm{N}=50)$ and females of $0.83 \pm 0.09 \mathrm{~cm}$ $\left(\mathrm{t}_{0.05} ; 98=2.69, \mathrm{p}<0.05\right.$; Figure $\left.2 \mathrm{c}\right)$. However, there were no differences in width at the widest point (cell base) between the sexes (males $=1.51 \pm 0.1 \mathrm{~cm}$; Females $=1.52 \pm$ $0.14 \mathrm{~cm} ; \mathrm{t}_{0.05 ; 98}=0.33, \mathrm{p}=0.77$, Fig $\left.2 \mathrm{~d}\right)$.

\section{Nesting activity of females}

The period of nesting activity was from April to August, coinciding with the rainy season at this field location. Females initiated nest-building immediately following mating, digging a new tunnel. Females were observed reusing tunnels of old nests, but excavating a short lateral tunnel into their own new cells. It is common to see nests of other years, which were exposed to the weather after juveniles developed and emerged. This fact indicates that the nesting location is being used for a long period by the species.

The first females became active around $0520 \mathrm{~h}$, and the last females were observed at $1640 \mathrm{~h}$. Despite being active until almost sunset, most construction and provisioning of the nests occurred in the morning (Fig. 3).

Nests were built close together in aggregations (dispersion index: $\mathrm{I}=6.79 ; \mathrm{n}=$ 162). The density of the nests in the area where nests were found was estimated to be 9.64 nests $/ \mathrm{m}^{2}$.

The excavation of the tunnel entrance and the excavation and shaping of the first cell within a nest required $327.8 \pm 79.9 \min (n=20)$. Excavation was characterized by multiple pauses, during which the female left the nest presumably to forage for nectar. It was common to see females starting an excavation in one place, then soon after, leaving that place to begin another nest somewhere else $(n=17)$. Some marked females took about two days to find an ideal place to start their nest excavation $(n=2)$.

After digging the main burrow, females begin to excavate and shape their brood cells. The cells are barrel-shaped with the bottoms slightly larger than the upper portions. The cell opening is circular and closed by a concave operculum, which is flat after being covered over with sand by the female. 

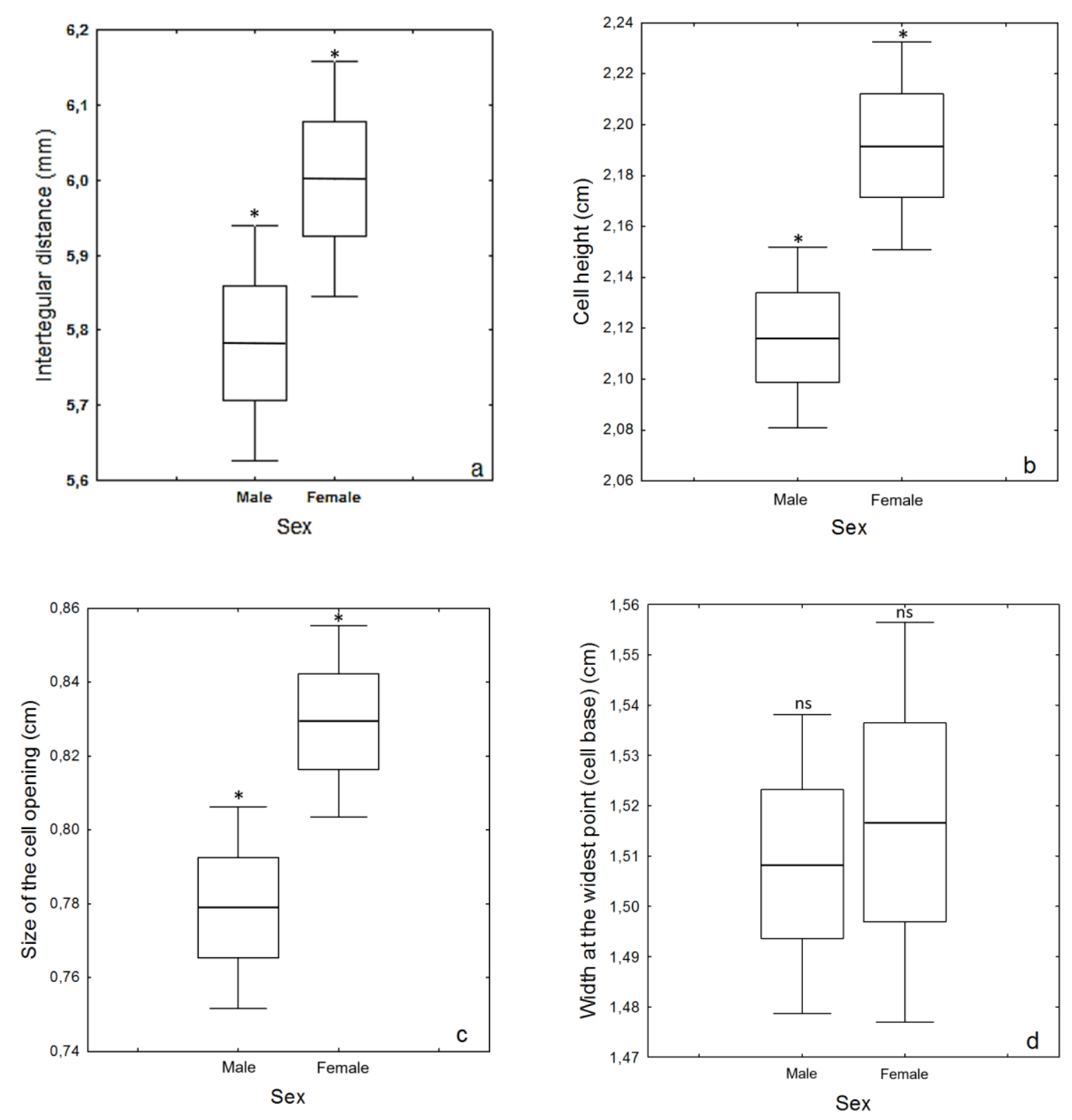

Fig. 2 Morphological analysis of 50 brood cells according to the sex of individuals in Centris (Paracentris) burgdorfi. a) Intertegular distance of random adult bees; b) Height of brood cells; c) diameter of the cell opening, and d) diameter of the cell base. The main horizontal line shows the mean, boxes represent standard error, and whiskers depict $95 \%$ intervals. Asterisk symbol $(*)$ represent significant differences and "ns" where they are not 


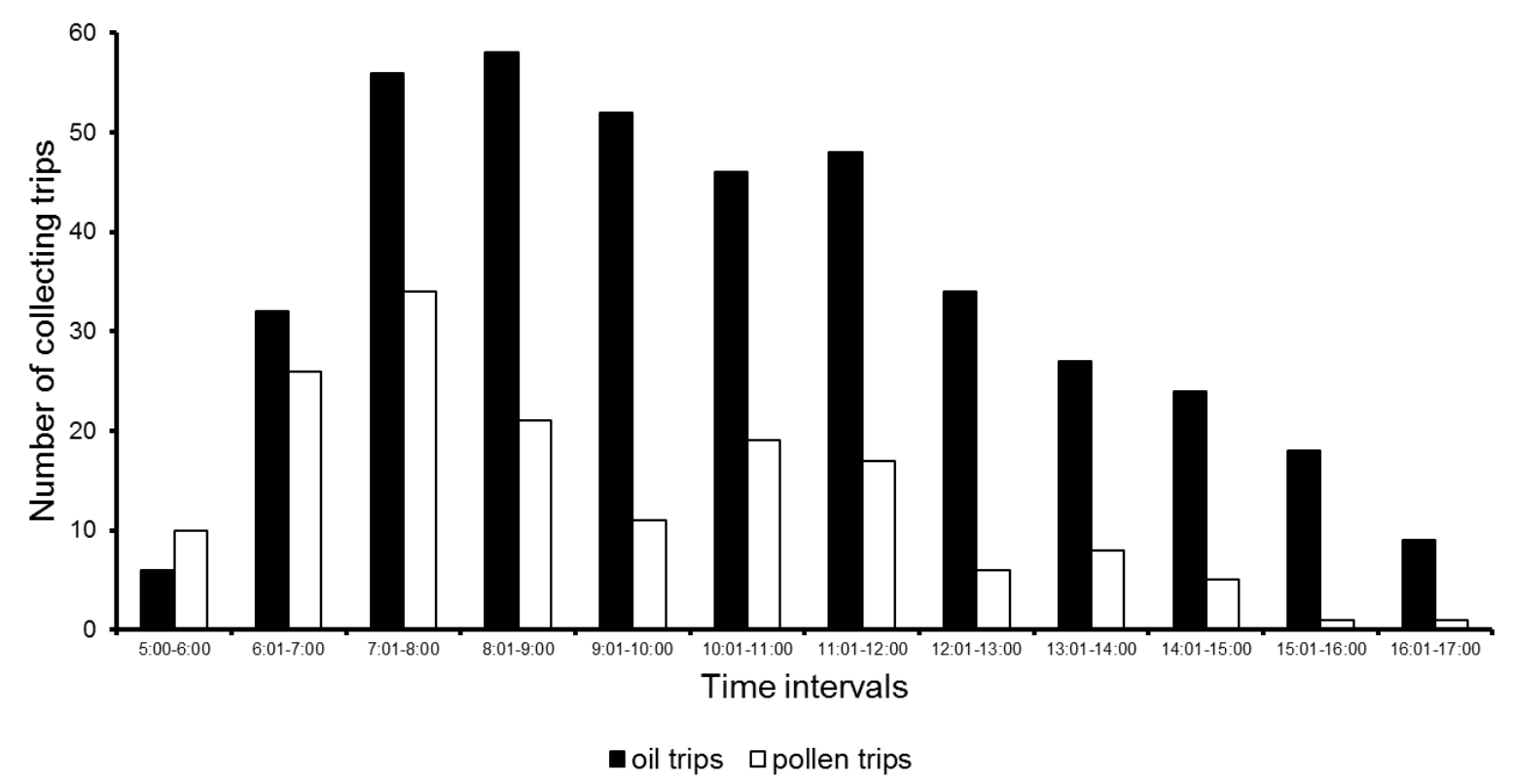

Fig. 3 Number of resource collection trips made by Centris (Paracentris) burgdorfi females in a dunes region in northeast, Brazil, separated by time class. Data are pooled across 20 females

Building a cell proceeded in the following manner: after building the entrance tunnel, the female shape the cell to be used for the floral resource provisions (pollen, nectar and oil). Egg-laying began after successive oil-collection trips, the floral oil being used to line the cell wall. Females made $9.62 \pm 1.81(n=91)$ trips to obtain floral oils in a quantity sufficient to line the cell walls. Upon return from a trip, the female always inspected the interior of the cell, then turned and entered the cell from the front, using her hind legs to mix/attach the sand grains to the top of the cell along the collected floral oil. After this behavior, females went back in the cell and initiated a rotating movement to deposit the mixture of oil + sand evenly over the cell wall.

After lining the cell, the female initiated the deposition of pollen, making an average of $4.91 \pm 1.33(\mathrm{n}=91)$ pollen-collection trips to construct a cell. For the deposition of pollen, the female re-entered the cell and made rotating movements while discharging her scopal loads (Fig. 4 a-d). We did observe that the cell linings hardened over a period of several days and also darkened in color with age. In our test with cells completely wrapped in a well-moistened paper, we observed that the water was not absorbed into the cell lining, indicating formation of an impervious water barrier. 


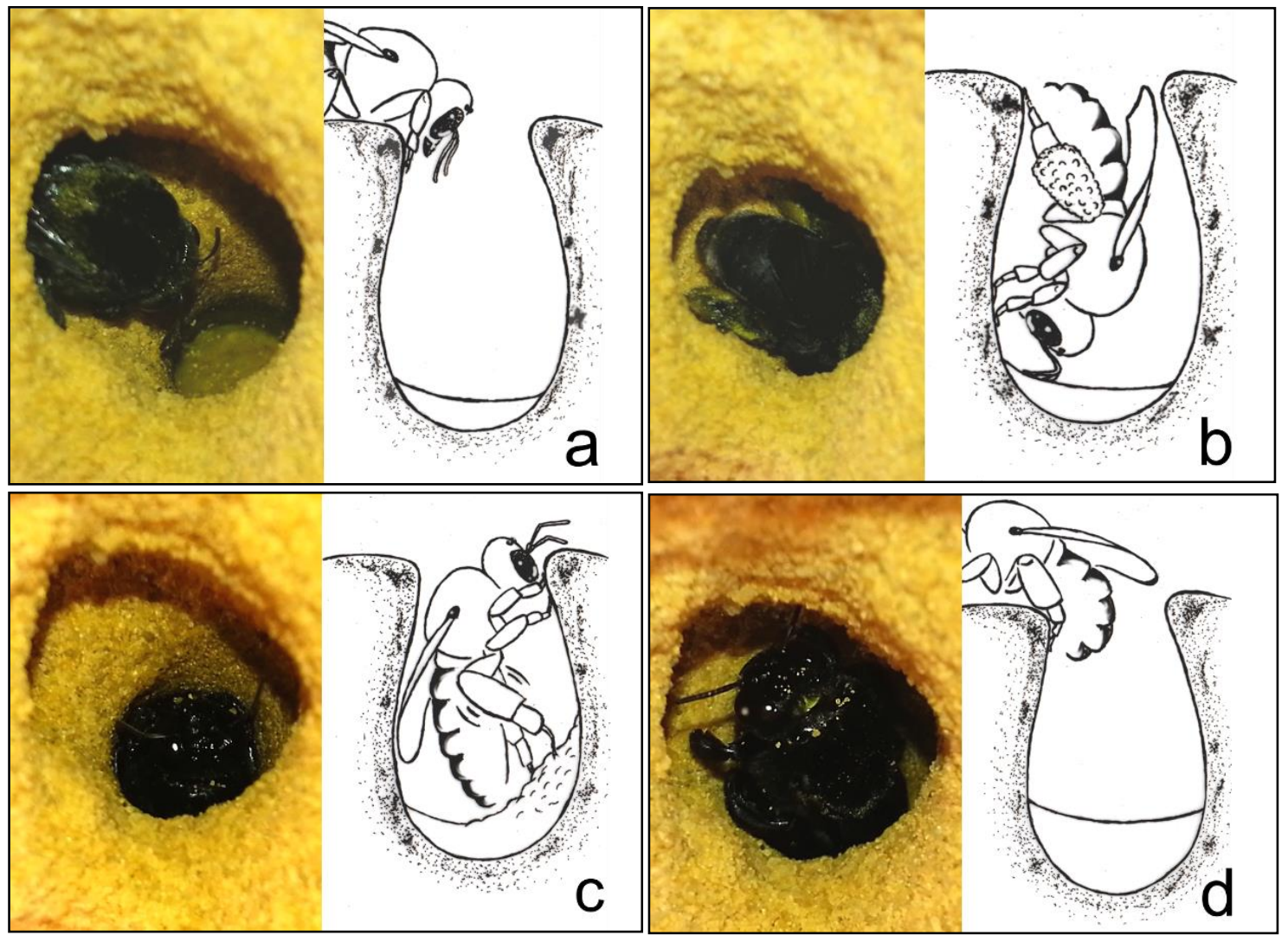

Fig. 4 Centris burgdorfi female during the construction of a cell: (a) Female returns to nest with pollen and (b) checks the cell before depositing material. (c) Using rotational movements, the female arranges the material uniformly using the hind legs and (d) exits again

The last stage of cell construction was the collection and addition of more floral oil that is used for larval feeding and construction of the cell's cover (that is, the 'operculum'). The female made an average of $2.63 \pm 0.77(n=91)$ oil-collecting trips to complete the cell. Females initially deposited a small amount of oil onto the pollen mass. The oil was thoroughly mixed into the pollen provisions, leading a uniform texture and consistency (Figure $5 \mathrm{a}-\mathrm{b}$ ). The female then hanging herself on the sides of the cell and with a swift rotary motion, deposited the remaining oil on top of the cell to close the cell completely. The resulting concave surface of the cell cap is then flattened by the female who deposits sand above it using front and hind legs, leaving the operculum flat (that is, without an apical process). The number of foraging trips made to provision cells differed in relation to what was being collected and for what purpose. The mean number of trips for oil collection for cell lining, for pollen collection, and for 
oil collection for larval sustenance differed significantly from each other $\left(\mathrm{F}_{0.05 ; 2}=\right.$ 614.02, p<0.0001) (Fig. 6).
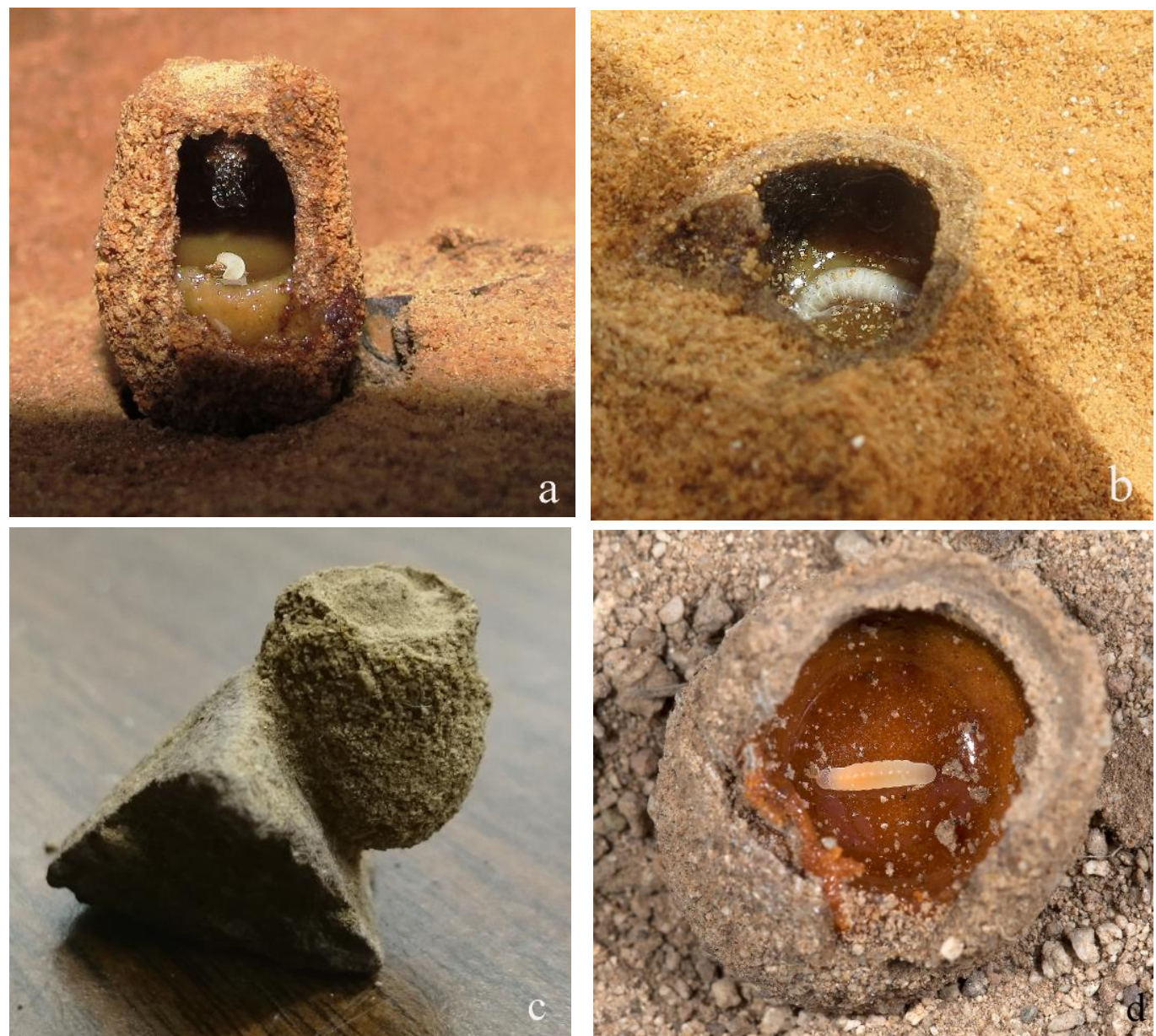

Fig. 5 Cells of the Centris (Paracentris) species of this study: a) Centris burgdorfi cell cross-section showing the egg deposited on top of the oil and pollen. Note the complete absence of an apical process (nipple) in the operculum (cell cap); b) Removal of the cell cap showing second instar of $C$. burgdorfi larva on top of a mass of pollen and oil; c) Centris pallida cell removed from the ground. Note the presence of an apical process (nipple) in the operculum; d) Removal of the cell cap showing second instar of $C$. pallida larva upon the mass of pollen and nectar. Photo in " $d$ " was kindly provided by Bruce D. Taubert 


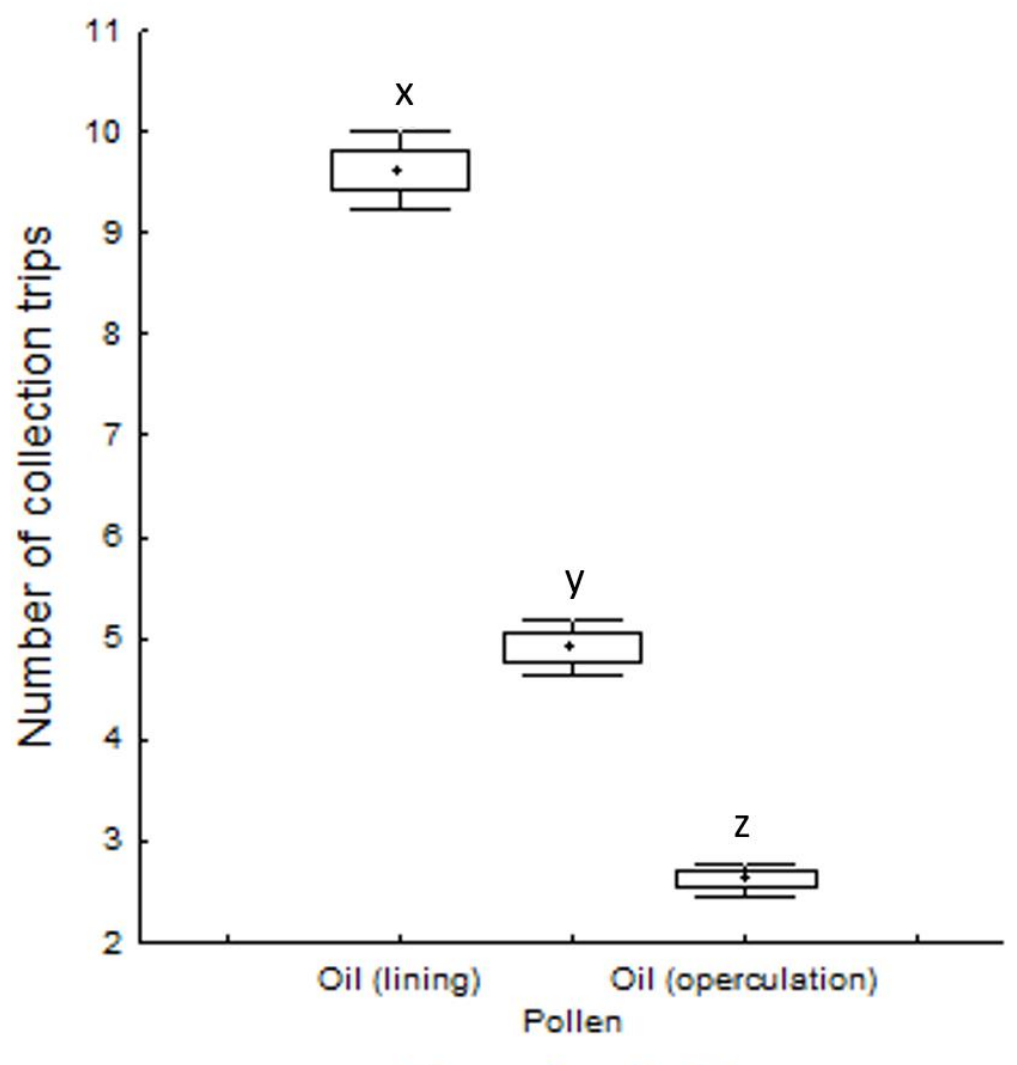

Type of material

Fig. 6 Number of trips made by Centris burgdorfi females in a dunes region in northeast, Brazil, in relation to the floral resources collected to provision and construct a cell. Bars sharing the same letters are not significantly different according to a Tukey's test at $\mathrm{p}<0.05$ in a two-way ANOVA. The main black dots show the mean, boxes represent standard error, and whiskers depict 95\% intervals

Females built from 1 to 7 cells in each nest. No marked females were observed to build more than one nest. Each cell required an average of about two and a half days to construct $(2.62 \pm 0.40, \mathrm{n}=20)$ (Table 1$)$. To unload oil and line the cell, females spent about 10.5 min (median), while the time spent to release her scopal pollen load into a cell was about 5 min (median). The time spend to use oil in operculation was also about 5 min (median). Differences in time spent in these different tasks were significant $(\mathrm{H}=196.4$; $\mathrm{p}<0.001)$ (Fig. 7). These times include both manipulation of the resource itself, as well as the time spent inside the nest in complementary activities. The average time to lay the egg was $1.92 \pm 0.21 \mathrm{~min}(\mathrm{n}=5)$. 
Table 1 Number of days spent by each Centris (Paracentris) burgdorfi female to construct one cell in a dunes region in northeast, Brazil

\begin{tabular}{ccccc}
\hline Year & Nest identification & Number of cells built & Activity days & Days/cell \\
\hline C14 & CB1 & 4 & 10 & 2.5 \\
& CB2 & 6 & 17 & 2.83 \\
CB3 & 3 & 7 & 2.33 \\
CB4 & 3 & 10 & 3.33 \\
CB5 & 7 & 14 & 2 \\
CB6 & 4 & 9 & 2.25 \\
CB7 & 4 & 10 & 2.5 \\
CB8 & 5 & 14 & 2.8 \\
CB9 & 3 & 10 & 3.33 \\
CB10 & 5 & 12 & 2.4 \\
CB11 & 1 & 3 & 3 \\
CB12 & 5 & 9 & 1.8 \\
CB13 & 6 & 17 & 2.83 \\
CB14 & 5 & 15 & 3 \\
CB15 & 7 & 16 & 2.29 \\
CB16 & 5 & 15 & 3 \\
CB17 & 4 & 10 & 2.5 \\
CB18 & 6 & 16 & 2.67 \\
CB19 & 6 & 15 & 2.5 \\
CB20 & 2 & 5 & 2.5 \\
\hline \hline Average & 4.55 & 11.70 & 2.62 \\
Standard deviation & 1.60 & 4.03 & 0.40 \\
\hline
\end{tabular}

The plants where the females collected resources (pollen, nectar and oil) occurred in the vicinity of nests (ca. $160 \mathrm{~m}$ ). The duration of foraging trips to these plants by females differed according to the resources collected (oil versus pollen). Females spent more time for pollen-collection trips (73 min., median) than for oilcollection trips (54 min., median) $[\mathrm{Z}(\mathrm{U})=7.77$; $\mathrm{p}<0.001]$ (Fig. 8). 


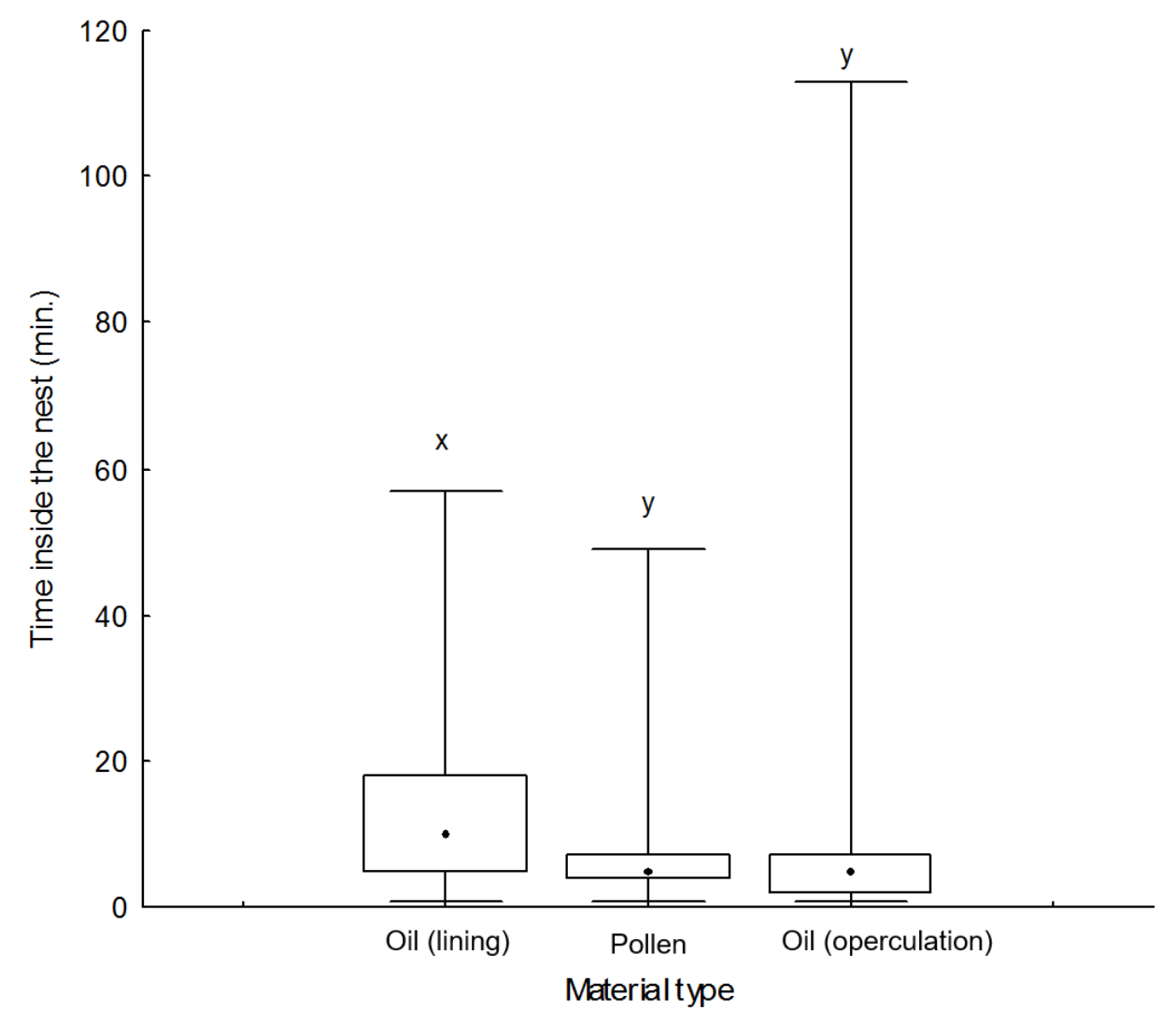

Fig. 7 Duration of time that Centris (Paracentris) burgdorfi females spent inside their nest according to the floral resource type being collected. Bars sharing the same letters are not significantly different according to a Dunn post hoc test in a Kruskal-Wallis. The main black dots show the median, boxes represent $25-75 \%$ interval of data, and whiskers depict minimum and maximum value of the data

The temperatures inside the nest were similar to the outside ambient temperatures in the early morning, when the lowest values were measured. The internal temperature barely reached $28{ }^{\circ} \mathrm{C}$ even in the hottest periods of the day, while the outside temperatures were above $30{ }^{\circ} \mathrm{C}$ between $0930 \mathrm{~h}$ and $1600 \mathrm{~h}$ (peaks above $36{ }^{\circ} \mathrm{C}$ at $1200 \mathrm{~h}$ ), the time period in which we also recorded the lowest humidity levels on site. The difference in average temperature between inside and outside the nest was significantly different $\left(\mathrm{t}_{0.05,25}=6.08, \mathrm{p}<0.001 ; \mathrm{n}=26\right)$ (Fig. 9). 


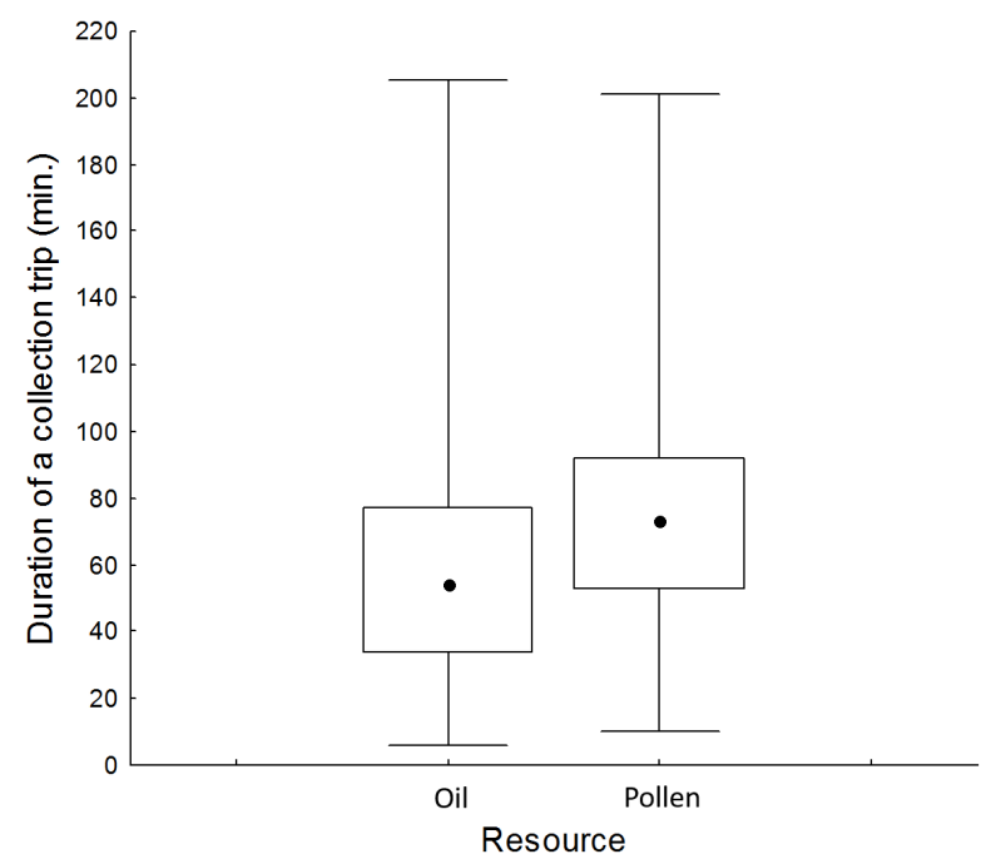

Fig. 8 Time spent by Centris (Paracentris) burgdorfi females away from their nests in a dunes region in northeast, Brazil, in gathering oil and pollen. The main black dots show the median, boxes represent $25-75 \%$ interval of data, and whiskers depict minimum and maximum value of the data

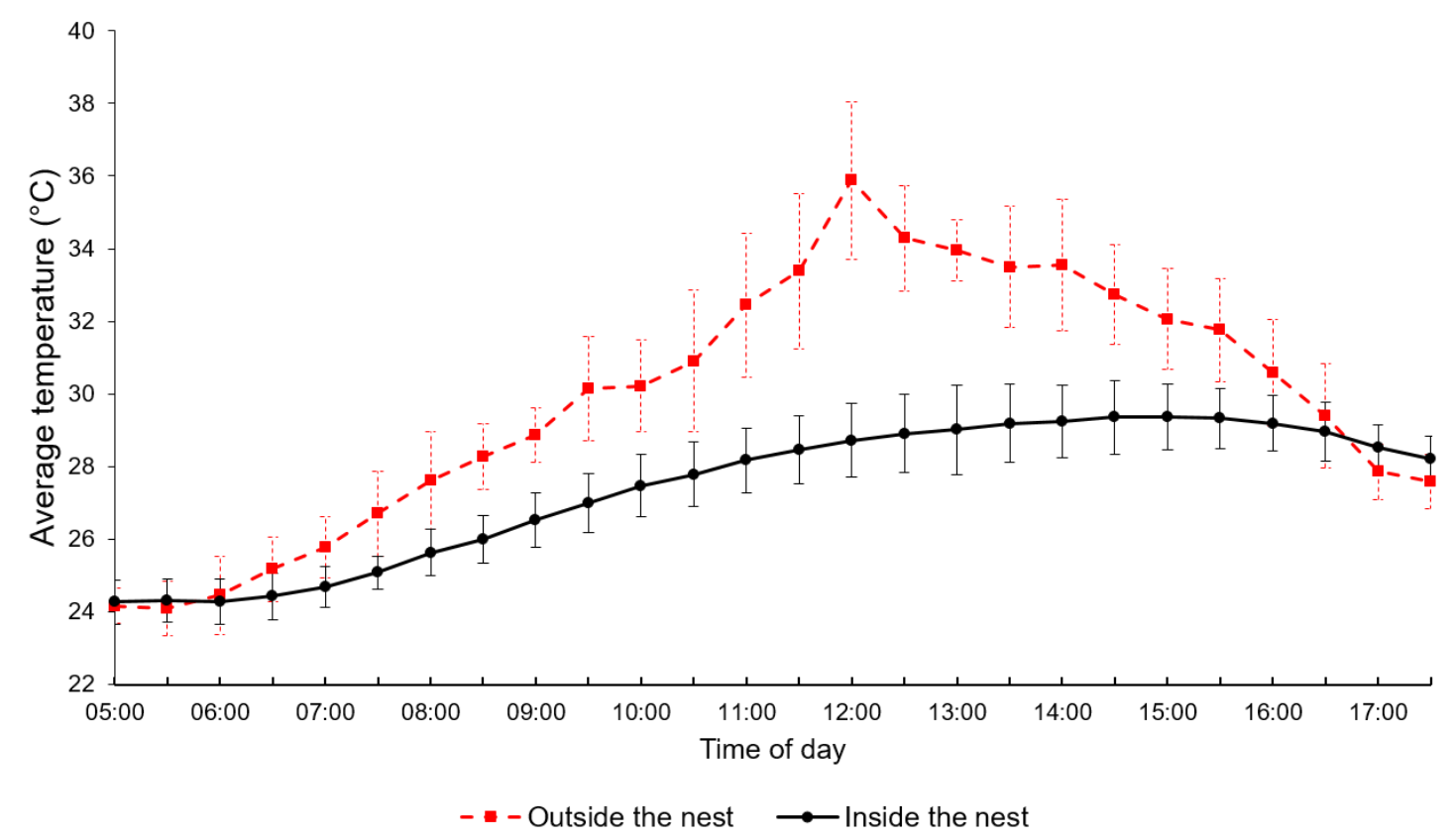

Fig. 9 Average temperatures measured simultaneously inside (continuous black line) and outside (dashed red line) the Centris (Paracentris) burgdorfi nests throughout the day, during 12 days. The symbols represent the mean and the bars are the standard deviations of the measurements 
Natural enemies were observed around the aggregation during the nesting period. It was common to see females of Mutillid (velvet ant) wasps walking on the petrified dunes. Female mutillids went everywhere, antennating the ground and occasionally entering open nest tunnels. When $C$. burgdorfi females were in a nest, the bee fought with the wasp, making the wasp fell from the surface of the dune to the ground. Ants were also seen along the aggregation entering the bee burrows. This activity began at sunset, when the increase in the number of ants circulating within the aggregation was noticeable. When the $C$. burgdorfi females reached the nest in the morning they sometimes encountered tunnels full of ants. Often females did not reenter their burrows until the ants had left. Mesoplia regalis Smith, a cleptoparasitic bee species, was also observed at the aggregation sites. These bees have a characteristic flight pattern, always close to the ground and very fast, making them difficult to see before landing. We observed individuals of $M$. regalis flying over the entrances, but none was observed to enter nests. Parasitic flies in the genus Anthrax were also collected at the nesting site. The Anthrax females were stationed at the base of the nesting aggregation, awaiting the departure of a female, at which time they hovered over the tunnel entrance and flicked eggs inside while still flying. Of the 124 cells maintained in the laboratory 10 (or $8 \%$ ) were parasitized. Three cells were parasitized by mutillid wasps: Hoplomutilla biplagiata Mickel $(\mathrm{n}=1)$ and Tallium aracati Couple $(n=2)$. These wasp larva produces a fibrous cocoon within the host cocoon, which makes it very different appearing when opened. In the rest of the parasitized cells we saw emerged Mesoplia regalis $(\mathrm{n}=1)$ and Anthrax sp. $(\mathrm{n}=6)$.

\section{Centris pallida nests}

We found a total of 75 nests of $C$. pallida in T. Hill, Tucson, AZ. The largest nesting activity was in April, with 72 found nests (Fig. 10). Nests were aggregated in open areas in a relatively soft and sandy soil. The nesting activity was noticeably greater in the morning when the temperatures are lower.

Nest entrances were marked by the presence of a tumulus of loose soil at one side. The excavated nests had a tunnel with a mean length of $19.46 \pm 1.1 \mathrm{~cm}$ and a mean depth in the soil of $7.38 \pm 0.26 \mathrm{~cm}(\mathrm{n}=36)$. Most females built only one cell per nest (79.41\% of the 36 excavated nests) and the remaining females built two cells per nest. Nests with two cells had only one access tunnel, that branched off toward each of the two cells. Each cell required on average almost two and a half days to construct $(2.43 \pm$ 
$0.56, \mathrm{n}=15)($ Table 2$)$. The cell has a barrel shape with a nipple process on top (Fig. 5c). The female laid the egg over a mass of nectar and pollen (Fig. 5d). After completing nest construction and provisioning, the female covered the access tunnel with earth and left the site.

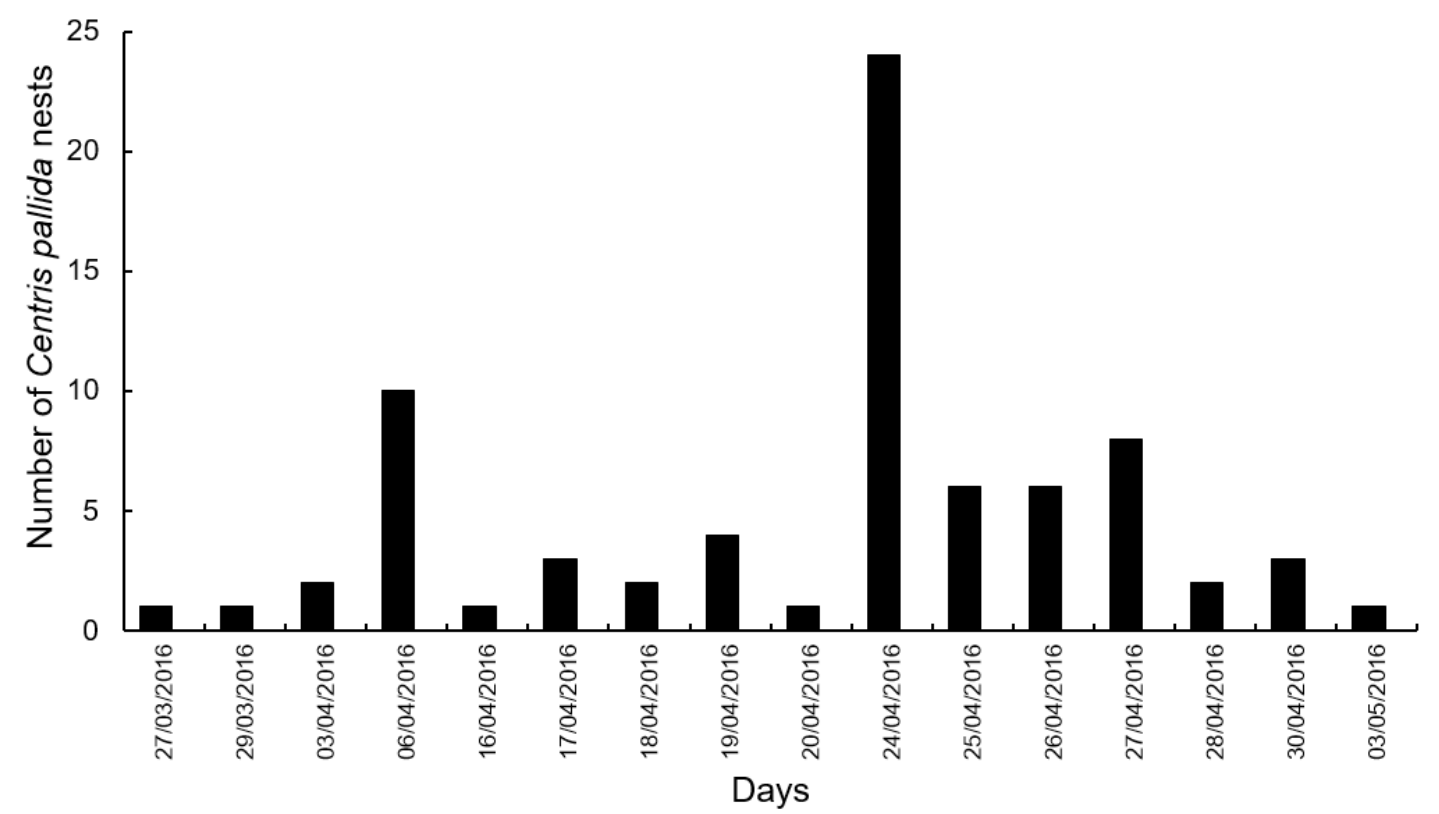

Fig. 10 Number of Centris (Paracentris) pallida active nests marked with flag in the Sonoran Desert, Tucson, Arizona

There was no statistical difference between the temperature $10 \mathrm{~cm}$ deep on the ground and ambient temperature $\left(\mathrm{t}_{0.05,47}=2.17, \mathrm{p}<0.03 ; \mathrm{n}=48\right)$. Nevertheless, daily temperatures is much reduced and more constant at $10 \mathrm{~cm}$ depth, relative to ambient. (Fig. 11). The temperature on the ground was higher than ambient temperature between $1800 \mathrm{~h}$ and $0700 \mathrm{~h}$ and lower than ambient temperature in the hottest periods of the day (between $0730 \mathrm{~h}$ and $1730 \mathrm{~h}$ ). The mean maximum ambient temperature was $42.68 \pm$ $4.76{ }^{\circ} \mathrm{C}(1200 \mathrm{~h})$ and the mean maximum temperature $10 \mathrm{~cm}$ deep on the ground was $41.21 \pm 3.46(1730 \mathrm{~h})$. 
Table 2 Number of days spent by each Centris (Paracentris) pallida female to construct one cell in the Sonoran Desert, Tumamoc Hill, Tucson, Arizona

\begin{tabular}{cccc}
\hline Nest identification & $\begin{array}{c}\text { Number of cells } \\
\text { built }\end{array}$ & $\begin{array}{c}\text { Activity } \\
\text { days }\end{array}$ & Days/cell \\
\hline CP1 & 1 & 2 & 2 \\
CP2 & 1 & 3 & 3 \\
CP3 & 1 & 3 & 3 \\
CP4 & 1 & 3 & 3 \\
CP5 & 1 & 3 & 3 \\
CP6 & 1 & 2 & 2 \\
CP7 & 1 & 3 & 3 \\
CP8 & 1 & 3 & 3 \\
CP9 & 1 & 2 & 2 \\
CP10 & 1 & 2 & 2 \\
CP11 & 1 & 2 & 2 \\
CP12 & 1 & 2 & 2 \\
CP13 & 2 & 3 & 1,5 \\
CP14 & 1 & 3 & 3 \\
CP15 & 2 & 4 & 2 \\
\hline Average & 1.13 & 2.67 & 2.43 \\
Standard deviation & 0.35 & 0.62 & 0.56 \\
\hline \hline
\end{tabular}

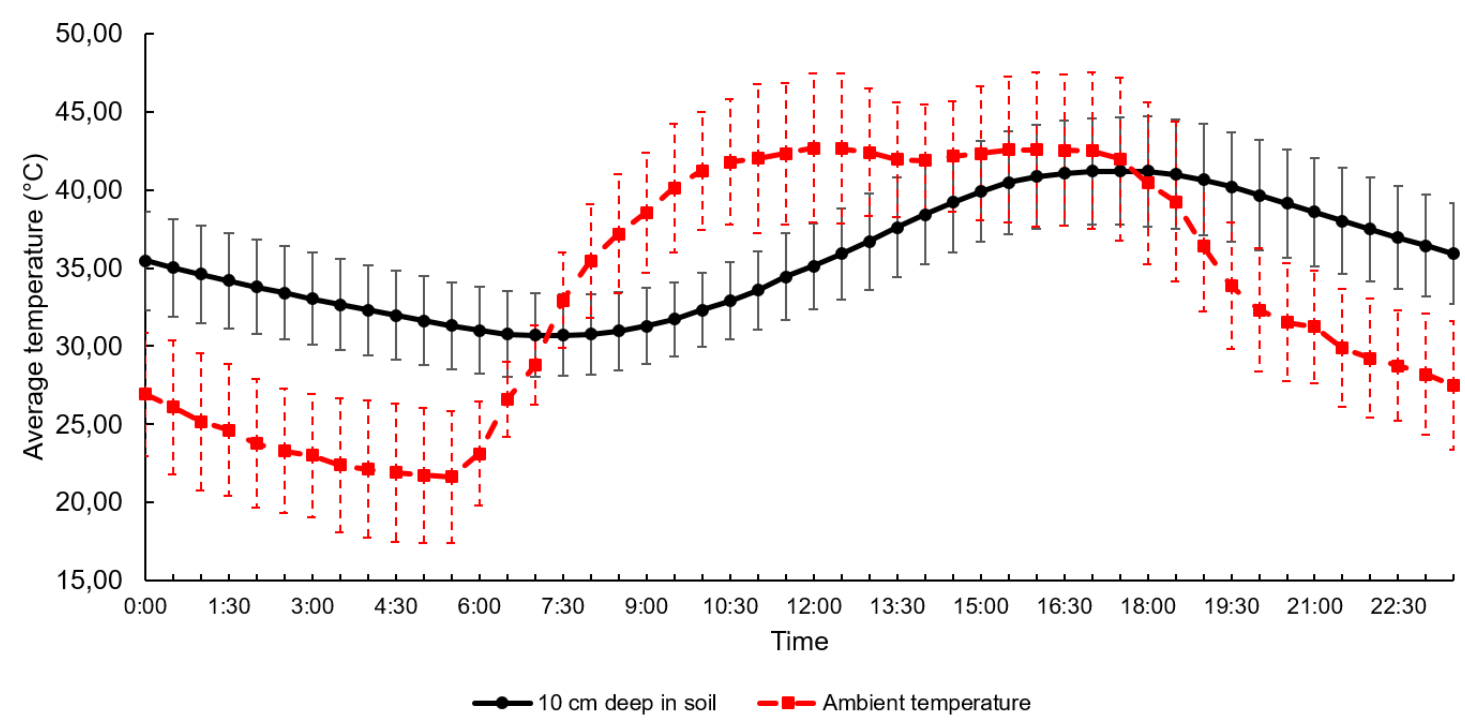

Fig. 11 Comparison of the average temperatures measured at $10 \mathrm{~cm}$ deep in soil (continuous black line), simulating the depth of a Centris (Paracentris) pallida nest in the Sonoran Desert, Tucson, Arizona, and the average ambient temperature (dashed red line) throughout the day. The temperatures were measured on each of 33 consecutive days. The symbols represent the mean and the bars are the standard deviations of the measurements 


\section{Discussion}

Our results provide detailed information about the nesting behavior of $C$. burgdorfi and additional information about $C$. pallida biology. The two species are active at the same time in different hemispheres, probably following the phenology of the plant species from which they forage. The different nesting substrates for the two species (cavities in petrified dunes for $C$. burgdorfi and ground for $C$. pallida) resulted in different relationships between the temperature inside the nest and the temperature of the environment. Besides the fact that $C$. pallida does not use floral oil in its nesting behavior, the two species nest in aggregations and spent similar amounts of time to construct a cell. However, the number of brood cells per nest was different.

Many species of Centris nest in aggregations [e.g. 328 nests $/ \mathrm{m}^{2}$ in $C$. caesalpiniae, 3 nests $/ \mathrm{m}^{2}$ in C. pallida (Rozen and Buchmann 1990), 40 nests $/ \mathrm{m}^{2}$ in $C$. aenea Lepeletier (Aguiar and Gaglianone 2003), 708 holes $/ \mathrm{m}^{2}$ in C. muralis Burmeister (Cilla and Rolón 2012) and 1.7 nests $/ \mathrm{m}^{2}$ in C. flavifrons Fabricius (Martins et al. 2014)]. Michener et al. (1958) also reported several species of bees nesting in aggregate in a vertical bank $1722 \mathrm{~m}$ long. We found many $C$. pallida and C. burgdorfi old cells at each nesting site, demonstrating that the place was used by previous generations. The question is why are nests found in aggregations?

First, some locations for nests are better than others. Desired locations are limited in area, so nests end up close to each other. For C. burgdorfi, the occurrence of aggregations could be related to preferences for the substrate chosen for nest construction. females have a clear preference for nesting in the hard-sandy substrate (petrified dunes) and these formations do not occur commonly in the landscape. Other aggregations of $C$. burgdorfi nests were found in similar dune structures indicating such a preference.

Second, bees could actively nest close to where other nests are because there are benefits of aggregations that outweigh the costs. Factors that favor aggregation behavior, such as facilitating encounters by partners for mating should offset those factors that disfavor such behavior, such as the build up of parasites or predators finding these food-rich dense targets (Michener et al. 1958). Despite the large aggregations found in C. caesalpiniae, Rozen and Buchmann (1990) never found C. caesalpiniae females nesting in the same spot again. For $C$. caesalpiniae the substrate may be not limited, but the cost of nesting in that area is higher that the benefits. For C. pallida, 
Alcock (1979) suggested that it was unlikely that the investment of time and energy in nest-site selection is related to the location of suitable soil types. The first and the second explanations are not mutually exclusive. Both could account for the aggregations.

Among the natural enemies of Centris are several species of cleptoparasitic bees in the Ericrocidini including Mesocheira, Mesoplia and Mesonychium (Snelling and Brooks 1985; Alves-dos-Santos 2009). During studies of the nesting biology of $C$. caesalpiniae in Arizona, Rozen and Buchmann (1990) observed a species of Ericrocis (E. lata Cresson) parasitizing the nests. However, since this genus does not occur in Brazil, it would not be expected that other species of Ericrocidini (e.g. Mesoplia regalis) would parasitize $C$. burgdorfi nests. Sabino et al. (2017) recorded that females of $C$. burgdorfi spend the night in plants and not in the nest. This is an unusual behavior in all Centris, and most bees, that could lead to more parasite attacks and more predation by other insects. Nevertheless, studies show that cleptoparasitic bees are active mainly during the day (Wcislo et al. 2004; Kelber et al. 2005) which would not necessarily mean a higher attack rate even with the unprotected nests in $C$. burgdorfi.

The nesting period of $C$. burgdorfi and $C$. pallida coincides with the flowering plants that females use for nectar (flight fuel) and for cell linings and provisioning of their cells. Most activity occurs in the cooler morning hours. In C. burgdorfi nesting area, the climate is very similar to that of the equatorial belt, with little variation in temperature throughout the year, but a pronounced division between the wet season and dry season. The emergence of $C$. pallida females closely coincided with the flowering of palo verdes (Parkinsonia florida and P. microphyllum) in the Sonoran Desert (Alcock et al. 1976). Decreases in female flight activity in the afternoon in both species is likely related to the high temperatures and possibly a decrease in the availability of floral resources on site by noon. Freitas and Pereira (2004) reported a large drop in the flight activity of Centris tarsata Smith, and Centris bicolor Lepeletier, around $1200 \mathrm{~h}$ due to the lower availability of pollen and oil after that period.

The difference between internal and external temperatures inside $C$. burgdorfi nests demonstrates that the substrate acts as a thermal insulator in protecting the developing brood. Despite the temperature inside and outside the nests of C. pallida not have statistically differentiated, the diurnal temperature pattern in soil suggests a relative constancy of temperature. This could have benefits for physiological processes, including growth processes, which may be optimized at a specific temperature. The 
development of immature bees is influenced by high temperatures, which can cause high mortality, particularly in the early larval stages (Frankie et al. 1993). Temperatures between $38{ }^{\circ} \mathrm{C}$ and $40{ }^{\circ} \mathrm{C}$ would be lethal to larvae of $C$. analis Fabricius (Frankie et al. 1988 ) and the same could happen with larvae of $C$. burgdorfi but apparently not for $C$. pallida. Nesting females of Nomia melanderi Cockerell, for example, respond to hot ambient temperatures by excavating nest burrows more deeply in the soil (Stephen 1965). Centris pallida appears to be extremely well adapted to the high temperatures in the desert; the high temperatures even at $10 \mathrm{~cm}$ soil depth suggest a higher thermal tolerance of the larvae. Furthermore, males of $C$. pallida exhibit some of the most precise thoracic thermoregulation observed for flying insects, presenting a relatively small water loss even in higher ambient temperatures (Roberts et al. 1998). Some species appear to nest in areas with narrowly defined environmental characteristics (as temperature, for example), whereas others seem to tolerate a much broader spectrum (Michener et al. 1958). We do not know the critical thermal maxima for bee larvae in the genus Centris and the actual temperature inside the cells, since we do not have this data for both species. This would be an interesting avenue for future research.

Centris burgdorfi females use floral oils from Krameria for construction of their cells (Sabino et al. unpubl. data). In contrast, C. pallida in Arizona does not visit plants that produce floral oils, and thus does not use oils to line its cells (Rozen and Buchmann 1990). Many Centris species of desert regions of the Americas show reduction and even the absence of basitarsal combs specialized for collection of floral oils (Neff and Simpson 1981). On the other hand, the loss of specialized structures for oil-collection in Centris muralis, in drier regions of Argentina, even in places with high local availability of oil-bearing flowers, suggests that availability of water may also be a crucial factor in nesting behavior of these xerophilic species (Cilla and Rolón 2012). In drier places, bees would not have to spend time and energy waterproffing their cells with oil. Despite being present in an environment with high temperatures throughout the year, $C$. burgdorfi faces a long and intense rainy season, with high rates of rainfall during the period of nest construction. We checked that the $C$. burgdorfi cells did not absorb water, as opposed to $C$. pallida cells that a disintegrated when placed in contact with water (Rozen and Buchmann 1990). Furthermore, floral oils are extremely rich in energy (nutrition) on a per unit volume compared to sugars and pollen grains. Floral oils are up to eight times richer in calories compared to nectar (Vogel 1989). Some Centris species use floral oil to feed their larvae and it is common to observe the egg or larva floating 
upon the oil layer (e.g. Gaglianone 2001; Aguiar and Gaglianone 2003; Rêgo et al. 2006). The same pattern of floating eggs was observed in C. pallida, but in this case the eggs were floating on nectar rather than oil (Rozen and Buchmann 1990). The mixture of floral lipids with pollen are the basic constituents of the larva feed in Centris species from Argentina (Simpson and Neff 1981).

The shape of the cells of $C$. burgdorfi is similar to other Centris species in the basic cell morphology (e.g. Vinson and Frankie 1977; Coville et al. 1983; Rozen and Buchmann 1990; Silva et al. 2001; Aguiar and Gaglianone 2003; Cilla and Rolón 2012; Martins et al. 2014). However, the operculum is outwardly concave, which differs from many other Centris species that add a central process or nipple on the operculum, as $C$. (Centris) aenea (Aguiar and Gaglianone 2003), C. (Centris) varia Erichson (cited by Coville et al 1983 as C. segregate Crawford), C. (Centris) flavifrons (Martins et al. 2014; Rêgo et al. 2006), C. (Hemisiella) transversa Pérez (Batra and Schuster 1977). This central process is present even in other Centris (Paracentris) species, as seen in $C$. pallida, C. rhodopus, C. cockerelli (Alcock et al. 1976) and C. caesalpiniae (Rozen and Buchmann 1990). According to these authors, the central process allows gas exchange between the external and the internal environments through a pore, because gases do not diffuse as easily through the cell wall, and the tough cells are also protected against external water and from natural enemies.

The average time spent by $C$. burgdorfi (2.59 days) and $C$. pallida (2.43) females to build a cell might be considered high when compared with other Centris species. For example, $C$. flavifrons spends an average of 1.61 days for the construction of each cell (Martins et al. 2014). But $C$. flavifrons and $C$. burgdorfi species differ in the number of oil-collection trips required for lining their cells. C. burgdorfi made 9.62 oilcollecting trips while $C$. flavifrons was observed taking only three trips for floral oils. Centris aenea was also reported to make fewer oil-collection trips to line its cells (two to three trips) and females spent less time in pollen collection (33.6 min in C. aenea versus $68 \mathrm{~min}$ in C. burgdorfi) (Aguiar and Gaglianone 2003). The time that female Centris spend gathering each type of floral resource is highly variable and likely related to the distance between the nest and the floral species that they utilize. Distance to the floral resources does not appear to be a problem for $C$. burgdorfi females since the plants used occur in the vicinity to the nesting site. Centris pallida is not an oilcollecting bee, and it seems collect pollen and nectar exclusively from Parkinsonia species (Alcock et al. 1976; Rozen and Buchmann 1990) that occurs abundantly 
throughout the nesting area. It is intriguing that the time of building a cell in $C$. pallida takes as long as in $C$. burgdorfi, since $C$. pallida females do not spend time with oilcollection trips.

Females of $C$. burgdorfi are larger than conspecific males and this has resulted in larger cells for females, and more provisioned pollen and oil per cell. Females can control the sex of each larva by withholding sperm at the time each egg is laid (Gerber and Klostermeyer 1970). Although we did not measure the size of pollen balls (provision masses), or the weight of fecal material, some authors have reported that body size is associated with the amount of food consumed by the larvae (e.g. Krombein 1967; Klostermeyer et al. 1973; Alcock 1979; Phillips and Klostermeyer 1978; Kim 1997). In Centris (Heterocentris) analis, Jesus and Garofalo (2000) observed behavioral differences in foraging in females according to whether they were provisioning a cell destined to be a female versus a male bee. A larger number of pollen-collecting trips were made when the cell produced a female offspring (Jesus and Garofalo 2000). These results indicate that the cost in the production of females is higher (Jesus and Garofalo 2000; Peterson and Roitberg 2006), which could affect local population sex ratios in the event of food shortages as during periods of drought. Previous studies in solitary bees, have shown that the ratio of males increases when food availability declines (Torchio and Tepedino 1980; Kim 1999).

For C. pallida, the fact that female body size influences brood cell size was confirmed by Alcock (1979). We do not know the relationship between the size of the cell and the sex of the brood in T. Hill but we observed males of different sizes (big/metandric, medium and small) at the nesting site. The size of a female, in $C$. pallida, is an influential factor in the size of the brood (Alcock 1979).

The present study contributes to our overall understanding of the nesting biology of Centris bees. We were able to follow step by step the construction of the cell in nature. Since $C$. burgdorfi is unusual in some aspects of its nesting behavior (e.g. nesting in the sandstone of stabilized sand dunes and females not spending the night in their burrows), it would be helpful to locate other more distant nesting localities for this bee, to confirm many of the observations at the Northeast Brazil study sites. We are undertaking an expanded study of $C$. burgdorfi by searching for other nesting sites of this remarkable Centridine bee. Our results also complement knowledge about $C$. pallida, but some information is not yet known, such as the actual temperature inside 
the cells, and the critical thermal maxima for larval development which is important in a desert habitat, particularly in light of climate warming.

Acknowledgments The authors are grateful to Paulo Roberto de Castro and Ana Carolina Oliveira da Silva for the help and all support in the field work and to Astrid Kleinert, Felipe Vivallo for comments and suggestions in the manuscript. The research was supported by Fundação de Amparo à Pesquisa do Estado de São Paulo (FAPESP) and Coordenação de Aperfeiçoamento de Pessoal de Nível Superior (CAPES).

\section{References}

Aguiar CML (2003) Flower visits of Centris bees (Hymenoptera: Apidae) in an area of caatinga (Bahia, Brazil). Stud Neotrop Fauna Environ 38 (1): 41-45

Aguiar CML, Gaglianone MC (2003) Nesting biology of Centris (Centris) aenea Lepeletier (Hymenoptera, Apidae, Centridini). Rev Bras Zool 20 (4): 601-606

Alcock J (1979). The relation between female body size and provisioning behavior in the bee Centris pallida Fox (Hymenoptera: Anthophoridae). J Kans Entomol Soc 52 (3): 623-632

Alcock J, Jones CE, Buchmann SL (1976) The nesting behavior of three species of Centris bees (Hymenoptera: Anthophoridae). J Kans Entomol Soc 49 (4): 469474

Alves-dos-Santos I (2009) Cleptoparasite bees, with emphasis on the oil bees hosts. Acta Biol Colomb 14: 107-114

Batra SWT, Schuster JC (1977) Nests of Centris, Melissodes, and Colletes in Guatemala (Hymenoptera: Apoidea). Biotropica 9 (2): 135-138

Bowers JE (2005) Effects of drought on shrub survival and longevity in the northern Sonoran Desert. J Torrey Bot Soc 132 (3): 421-431

Buchmann SL (1987) The ecology of oil flowers and their bees. Ann Rev Ecol Syst 18: 343-369

Cane JH (1987). Estimation of bee size using intertegular span (Apoidea). J Kans Entomol Soc 60 (1): 145-147

Cilla G, Rolón G (2012) Macroscopic and microscopic studies of the nests and the stages involved in the nesting process of Centris muralis Burmeister 
(Hymenoptera: Apidae: Centridini) bee in the adobe walls, in La Rioja, Argentina. Biologia 67 (3): 573-583

Coville RE, Frankie GW, Vinson SB (1983) Nests of Centris segregata (Hymenoptera: Anthophoridae) with a review of the nesting habits of the genus. J Kans Entomol Soc 56 (2): 109-122

Frankie GW, Vinson SB, Newstrom L, Barthell JF (1988) Nest site habitat preferences of Centris bees in the Costa Rican dry forest. Biotropica 20 (4): 301-310

Frankie GW, Newstrom L, Vinson SB, Barthell JF (1993) Nesting-habitat preferences of selected Centris bee species in Costa Rican dry forest. Biotropica 25 (3): 322333

Freitas BM, Paxton RJ (1998) A comparison of two pollinators: the introduced honey bee Apis mellifera and an indigenous bee Centris tarsata on cashew Anacardium occidentale in its native range of NE Brazil. J Appl Ecol 35: 109-121

Freitas BM, Pereira JOP (2004) Crop consortium to improve pollination: can West Indian Cherry (Malpighia emarginata) attract Centris bees to pollinate cashew (Anacardium occidentals). In: Freitas BM, Pereira JOP (eds) Solitary bees: conservation, rearing and management for pollination. Fortaleza: Imprensa Universitária, pp: 193-201

Gaglianone MC (2001) Nidificação e forrageamento de Centris (Ptilotopus) scopipes Friese (Hymenoptera, Apidae). Rev Bras Zool 18 (Supl 1): 107-117

Garófalo CA, Camillo E, Serrano JC (1989) Espécies de abelhas do gênero Centris (Hymynoptera, Anthophoridae) nidificando em ninhos-armadilha. Ci Cult 41: 799

Gerber HS, Klostermeyer EC (1970) Sex control by bees: a voluntary act during fertilization. Science 167: 82-84

INMET/UFRN (2002) Instituto Nacional de Meteorologia/UFRN. Boletins Climatológicos: anos 1984 a Maio/2002. Estação Climatológica Principal. Natal

Janvier H (1926). Recherches biologiques sur les Hymenopteres du Chili. Ann Sei Nat Zool 10: 133-268

(1955) Le nid et la nidification chez quelques abeilles des Andes tropicales. Ann Sci Nat Zool 17 (11): 311-49

Jesus BMV, Garófalo CA (2000) Nesting behavior of Centris (Heterocentris) analis (Fabricius) in southeastern Brazil (Hymenoptera, Apidae, Centridini). Apidologie 31: 503-515 
Kelber A, Warrant EJ, Pfaff M, Walle'n R, Theobald JC, Wcislo WT, Raguso RA (2005) Light intensity limits foraging activity in nocturnal and crepuscular bees. Behav Ecol 17 (1): 63-72

Kim JY (1997) Female size and fitness in the leaf-cuter bee Megachile apicalis. Ecol Entomol 22: 275-282 (1999) Influence of resource level on maternal investment in a leaf-cutter bee (Hymenoptera: Megachilidae). Behav Ecol 10: 552-556

Klostermeyer EC, Mech SJ, Rasmussen WB (1973) Sex and weight of Megachile rotundata (Hymenoptera: Megachilidae) progeny associated with provision weights. J Kansas Ent Soc 46: 536-548

Krombein KV (1967) Trap-nesting wasp and Bees: life histories nest and associates. Smithsonian Press, Washington, USA

Martins CF, Peixoto MP, Aguiar CML (2014) Plastic nesting behavior of Centris (Centris) flavifrons (Hymenoptera: Apidae: Centridini) in an urban area. Apidologie 45 (2): 156-171

Martins AC, Melo GAR (2015) The New World oil-collecting bees Centris and Epicharis (Hymenoptera, Apidae): molecular phylogeny and biogeographic history. Zool Scr 1-12.

Michener CD, Lange RB, Bigarella JJ, Salamuni R (1958) Factors influencing the distribution of bees' nests in earth banks. Ecology 39 (2): 207-217

Neff JL, Simpson BB (1981) Oil-collecting structures in the Anthophoridae (Hymenoptera): Morphology, function, and use in systematics. J Kansas Entomol Soc 54 (1): 95-123

Neto OF, Costa FAA, Severo RNF, Júnior OFS, Scudelari AC (2005) Estudo da dinâmica de Falésias do município de Tibau do Sul - RN. Anais do $11^{\circ}$ Congr. Brasil. Geologia de Engenharia e Ambiental. Florianópolis - SC.

Nogueira AMB (1981) O cenozoico continental da região de Natal. Dissertation, Universidade Federal de Pernambuco

Oliveira R, Schlindwein C (2009). Searching for a manageable pollinator for acerola orchards: the solitary oil-collecting bee Centris analis (Hymenoptera: Apidae: Centridini). J Econ Entomol 102 (1): 265-273

Perterson JH, Roitberg BD (2006) Impacts of flight distance on sex ratio and resource allocation to offspring in the leafcutter bee, Megachile rotundata. Behav Ecol Sociobiol 59: 589-596 
Phillips JK, Klostermeyer EC (1978). Nesting behavior of Osmia lignaria propinqua Cresson (Hymenoptera: Megachilidae). J Kansas Ent Soc 51: 91-108

Rêgo MMC, Albuquerque PMC, Ramos MC, Carreira LM (2006) Aspectos da Biologia de Nidificação de Centris flavifrons (Friese) (Hymenoptera: Apidae, Centridini), um dos Principais Polinizadores do Murici (Byrsonima crassifolia L. Kunth, Malpighiaceae), no Maranhão. Neotrop Entomol 35 (5): 579-587

Roberts SP, Harrison JF, Hadley NF (1998). Mechanisms of thermal balance in flying Centris pallida (Hymenoptera: Anthophoridae). J Exp Biol 201(15): 2321-2331.

Roubik DW (1989) Ecology and Natural History of Tropical Bees. Cambridge Tropical Biology Series. Cambridge University Press

Rozen JG, Buchman SL (1990) Nesting biology and immature stages of the bees Centris caesalpiniae, C. pallida and the cleptoparasite Ericrocis lata (Hymenoptera: Apiodea: Anthophoridae). Am Mus Novit 2985: 1-30

Sabino WO, Silva CI, Alves-dos-Santos I. (2017). Mating system and sleeping behaviour of the Male and Female Centris (Paracentris) burgdorfi Friese (Apidae, Centridini). J Insect Behav 30 (1): 103-118

Silva FO, Viana BF, Neves EL (2001) Biologia e arquitetura de ninhos de Centris (Hemisiella) tarsata Smith (Hymenoptera, Apidae, Centridini). Neotrop Entomol 30 (4): 541-545

Silva CI, Queiroz EP, Faria LB, Alves-dos-Santos I (2012) Especialização na dieta de Centris (Paracentris) burgdorfi Friese, 1900 (Apidae, Centridini). Anais do X Encontro Sobre Abelhas. Ribeirão Preto: FUNPEC

Silveira FA, Melo GAR, Almeida EAB (2002) Abelhas brasileiras: sistemática e identificação. Belo Horizonte

Simpson BB, Neff J (1981) Floral rewards: alternatives to pollen and nectar. Ann Mo Bot Gard 68: 301-322

Snelling RR, Brooks RW (1985) A review of the genera of cleptoparasitic bees of the tribe Ericrocini (Hymenoptera: Anthophoridae). Contr Sci Mus Nat His Los Angeles 369: 1-34

Sokal R, Rohlf FJ (1995) Biometry - The principles and practice of Statistics in biological research. New York, W. H. Freeman and Co

Stephen WP (1965) Temperature effects on the development and multiple generations in the alkali bee, Nomia melanderi Cockerell. Entomol Exp Appl 8(3): 228-240 
Torchio PF, Tepedino VJ (1980) Sex ratio, body size and seasonality on a solitary bee, Osmia lignaria propinqua Cresson (Hymenoptera: Megachilidae). Evolution 34: 993-1003

Turner RM, Brown DE (1982) Sonoran deserts crub. Desert Plants 4: 181-221

Vinson SB, Frankie GW (1977) Nests of Centris aethyctera (Hymenoptera: Apoidea: Anthophoridae) in the dry forest of Costa Rica. J Kans Entomol Soc 50 (2): 301311

Vivallo F, Zanella FCV (2012) A new species of Centris (Paracentris) Cameron, 1903 from northeastern Brazil, with a key for the Centris species of the Caatinga region (Hymenoptera: Apidae). Zootaxa 3298: 1-16

Vivallo F (2015) State of the art and challenges of the taxonomy of the species of the tribe Centridini (Apidae: Apinae). In: Simões ZLP, Almeida JMJ, Almeida EAB (eds) Anais do XI Encontro sobre Abelhas. Ribeirão Preto, pp. 99-100

Vogel S (1974) Ölblumen und ölsammelnde Bienen. Trop Subtrop Pflanzenwelt 7: 285547

(1989) Fettes Öl als Lockmittel. Erforschung der Ölbietenden Blumen und ihrer Bestäuber. Akademie der Wissenschaften und der Literatur Mainz - 1949-1989. Franz Steiner Verlag. pp. 113-130

Wcislo WT, Arneson L, Roesch K, Gonzalez V, Smith A, Fernández H (2004) The evolution of nocturnal behaviour in sweat bees, Megalopta genalis and $M$. ecuadoria (Hymenoptera: Halictidae): an escape from competitors and enemies? Biol J Linnean Soc 83: 377-387

Zanella FCV (2002) Sistemática, filogenia e distribuição geográfica das espécies sul americanas de Centris (Paracentris) Cameron, 1903 e de Centris (Penthemisia) Moure, 1950, incluindo uma análise filogenética do "grupo Centris" sensu Ayala, 1998 (Hymenoptera, Apoidea, Centridini). Rev Bras Entomol 46: 435488

Zar JH (1996) Biostatistical Analysis. $3^{\text {a }}$ Ed. New Jersey: Prentice Hall 
CAPIITOLO ஓ

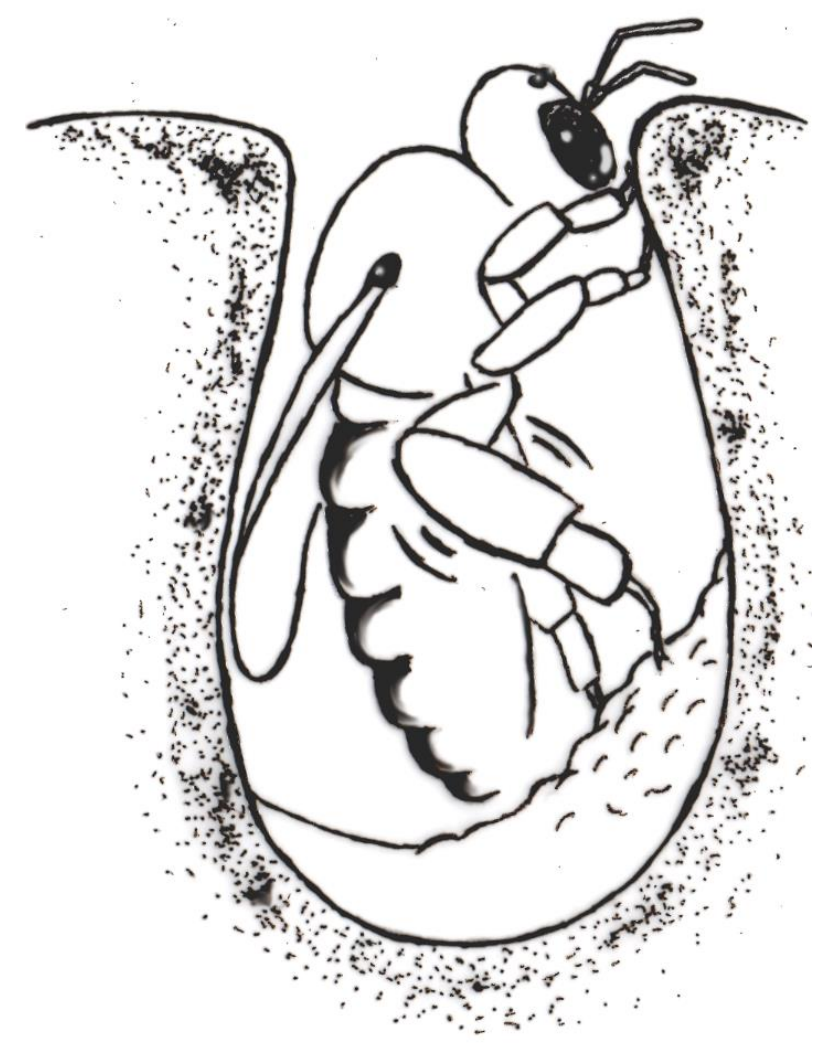




\title{
CHAPTER 3
}

Manuscript formated to be submitted in the Arthropod-Plant Interactions

\section{PLASTICITY OF THE TROPHIC NICHE OF Centris (Paracentris) burgdorfi (APIDAE, CENTRIDINI)}

\author{
William O. Sabino* . Isabel Alves-dos-Santos . Cláudia Inês da Silva \\ Departamento de Ecologia, Instituto de Biociências, Universidade de São Paulo, São \\ Paulo, Brasil. *sabinobees@usp.br (+55)11995614439
}

\begin{abstract}
Centris species collect floral oil and use this resource in larval food and for waterproofing their cells. We investigated the trophic niche of three distinct populations of Centris burgdorfi, a bee widely distributed in Brazil, through pollen collected from the female body. We aim to know if there is a plasticity regarding sources of oil, nectar and pollen in different regions in Brazil. Through the pollen, we also try to know if the source of oil used corresponds to the collector apparatus of the female. In total, we sampled 150 females of $C$. burgdorfi and their associated pollen in three distinct habitat types across Brazil. We prepared pollen through the acetolysis process and performed quantitative analysis on a total of 400 grains per bee. We identified a total of 41 plant species belonging to 18 families used by $C$. burgdorfi. While none of the plants species used by $C$. burgdorfi were shared between areas, the Chamaecrista genus was present in the bees' diet of the three sites. The oil source came from plants of the genus Krameria - a genus with epithelial elaiophores. In regions where the Krameriaceae family was not present (e.g. southern Brazil) bees used Angelonia integerrima, a plant with trichomate elaiophores, demonstrating that Centris burgdorfi is plastic in its dietary breadth between the studied regions. We discuss these results in the context of trophic niche plasticity, and its role in permitting wide species distributions even in the absence of preferred floral sources.
\end{abstract}

Key-words: Elaiophores . Oil-collecting bees . Floral oil-producing plants . Solitary bees 
Resumo As espécies Centris coletam óleo floral e utilizam esse recurso no alimento larval e para a impermeabilização de suas células. Investigamos o nicho trófico de três populações distintas de Centris burgdorfi, uma abelha amplamente distribuída no Brasil, por meio do pólen coletado do corpo das fêmeas. Objetivamos saber se existe uma plasticidade em relação às fontes de óleo, néctar e pólen em diferentes regiões do Brasil. Através do pólen, procuramos descobrir se a fonte de óleo utilizada corresponde ao aparelho colector da fêmea. No total foram amostradas 50 fêmeas de C. burgdorfi e seu pólen associado em três tipos distintos de habitat no Brasil. Preparamos o pólen através do processo de acetólise e realizamos análise quantitativa em um total de 400 grãos por abelha. Identificamos um total de 41 espécies de plantas pertencentes a 18 famílias utilizadas por $C$. burgdorfi. Embora nenhuma das espécies de plantas utilizadas por C. burgdorfi tenha sido compartilhada entre as áreas, o gênero Chamaecrista esteve presente na dieta das abelhas nos três locais. A fonte de óleo veio de plantas do gênero Krameria - que pussuem elaióforos epiteliais. Em regiões onde a família Krameriaceae não estava presente (por exemplo, no sul do Brasil), as abelhas utilizaram Angelonia integerrima, uma planta com elaióforos tricomáticos, demonstrando que o Centris burgdorfi possui plasticidade na sua dieta entre as regiões estudadas. Discutimos esses resultados no contexto da plasticidade do nicho trófico, e seu papel em permitir uma ampla distribuição de espécies mesmo na ausência de fontes florais preferidas.

Palavras-chave: Abelhas coletoras de óleo . Abelhas solitárias . Elaióforos . Plantas produtoras de óleo floral 


\section{Introduction}

Access the entire niche of one specie has pratical difficulties due to the complexity ndimensional. All niche quantifications require specification of what counts as the "environment", which may be complex and require very specific natural history information (Holt 2009). Habitat use, diet and environmental tolerance are the most frequently measured niche subsets (Slatyer et al. 2013). Trophic niche width, often assessed using dietary diversity, is the most tractable and frequently studied component of niche space (Bearhop et al. 2004).

Restricted interactions between bees and plants are rare in nature (Thompson 2006), and what we see are variations in these interactions across time and space (Herrera 1988; Waser et al. 1966; Kearns et al. 1998). Species of bees with a more restricted diet have a limited distribution according to the plants from which they feed (Michener 1979). Therefore, species that exhibit some plasticity in the interaction may be able to live even in locations with different plant groups.

The eusocial bees should provide food resources to offspring throughout the year. Honeybees, for example, which rely upon a seasonal progression of flowering among species to maintain their hives, could not have evolved until local communities included multiple plant species that flowered at different times (Thompson 2006). On the other hand, some species of bees have developed a morphology or a specialized behavior to collect floral resources of difficult access or extremely specific (Schlindwein 2000) and many times are active only in a determinate part of the year.

There are several types of specialization in collection of floral resources among bees. The use of a single species of plant for pollen collection (i.e. monolecty) is extremely rare among bees (Cane and Sipes 2006; Minckley and Roulston 2006). Despite a broad spectrum of available pollen sources, several species of bees restrict the larval diet only a few plant species of the same genus or family. This phenomenon is known as oligolecty and occurs in at least 12 bee tribes (Schlindwein 1998, 2004a). At the other extreme, the polylecty species collect pollen from many plant species from different lineages (Cane and Sipes 2006; Roulston and Minckley 2006). Among the many polylecty species are mainly the eusocial species (Ramalho et al. 1990; Aleixo et al. 2013) and the bees of the genus Centris that are, in their majority, considered polylecty (Schlindwein 2000, 2004b). It is possible to argue that high generalization should lead to high local abundance (as well as broad geographic distributions) because 
generalists are able to exploit a broad range of resources, thus giving them an advantage over specialists (Brown 1984).

In addition to pollen, Centris females collect floral oil and use this resource to waterproofing their brood cells (Vogel 1990). Furthermore, floral oil provides more than twice energy of nectar, which makes many species opt for this resource to feed the larvae (Buchmann 1987). The production of floral oil is present in 11 families of plants that occur mainly in tropical and subtropical regions (Renner and Schaefer 2010). Floral oil is produced in secretory glands called elaiophores, which may be in the form of epithelium, as seen in Malpighiaceae and Krameriaceae, or trichomes such as Calceolariaceae, Cucurbitaceae, Iridaceae, Myrsinaceae, Plantaginaceae, Scrophulariaceae, Solanaceae and Stilbaceae (Vogel 1974; Buchmann 1987; Alves dos Santos et al. 2007). To collect, handle and transport floral lipids, Centris bees have elaborate setal combs and pads found on the fore- and midlegs (Roberts and Vallespir 1978; Neff and Simpson 1981; Roig-Alsina 2000; Alves-dos-Santos et al. 2007). We called "foulegged pattern" when the female has giant setae well developed and with triangular and spatulate apexes in the basitarse of the fore and mid-legs (Vogel 1974).

Here, we investigated the trophic niche of three distinct populations of Centris (Paracentris) burgdorfi, that occur in different biomes in Brazil, through the pollen taken from the female's body. We explored the interaction network structure between bees and plants in each place. We asked three questions: 1. which plant species are used to feed the adult and immature? 2. Is there fidelity in the use of some plant genus? 3. what species of floral oil-producing plants with what kind of elaoiphore the females use? According to the wide distribution of the $C$. burgdorfi in Brazil, we expect that there is a plasticity in the use of floral resources.

\section{Material and Methods}

\section{Study site}

We performed the study at three locations in Brazil: Natal in northeastern, Cavalcante in Center-west and Ponta Grossa in the south. In Natal, in the state of Rio Grande do Norte, we obtained pollen samples in the dunes known as the "Deserto dos Anjos" where $C$. burgdorfi nest $\left(05^{\circ} 36^{\prime} \mathrm{S}, 35^{\circ} 14^{\prime} \mathrm{W}\right.$; elevation: $41 \mathrm{~m}$; Fig. 1a). The coastal dunes are located in a transition zone between the climatic types As'- hot and humid due to 
high rainfall and Bsh - hot semi-arid due to strong evaporation, according to Köppen (1900). The average temperature is around $26.7^{\circ} \mathrm{C}$ and the rainy season runs from March to August, with an average annual rainfall of $1643.48 \mathrm{~mm}$ (INMET / UFRN 2002). We collected samples in April $2011(n=15)$ and April and May $2014(n=35)$.

In Cavalcante, in the state of Goiás, the sample place is inside the protected area called "Chapada dos Veadeiros" (GO) (13³7'35.6"S, 47²9'08.0"W; elevation 853m; Fig. 1b). According to Köppen (1900) the climate is Aw, with average annual temperatures between $19^{\circ} \mathrm{C}$ and $22^{\circ} \mathrm{C}$ and average annual rainfall between $2,400 \mathrm{~mm}$ and 2,800 $\mathrm{mm}$ (Cardoso et al. 2014). The region is under the domain of Cerrado with the presence of plants typical of altitude fields associated with rock formations. We collected the samples in April 2015 ( $n=22)$, and April $2017(n=28)$ during the rainy season.

In Ponta Grossa, in the state of Paraná, we collected the samples within the "Parque Estadual de Vila Velha" (PR) $\left(25^{\circ} 13.839\right.$ 'S, 4959.561'W; elevation $1017 \mathrm{~m}$; Fig. 1c). The climate according to Köppen (1900) classification is Cfb type, with an average temperature in the coldest month below $18^{\circ} \mathrm{C}$, with cool summers, average temperature in the hottest month of $22^{\circ} \mathrm{C}$ and no dry season (Gonçalves and Melo 2005). The area has a combination of landscapes including altitudinal field with predominance of Asteraceae, Araucaria forest and rupicolous vegetation associated with sandstones (Gonçalves and Melo 2005). We collected samples in warmer periods in the region in December $2014(n=18)$ and November $2016(n=32)$. Each region stay at least $1400 \mathrm{~km}$ away to another.

\section{Data collection}

We used an entomological nest to collect $C$. burgdorfi females in flight activity in the three study sites. In total, we collected 50 females in the costal dunes (RN), 50 females in the Cerrado (GO) and 50 females in the altitudinal field (PR). The pollen was removed by washing the female using a falcon tube with $2 \mathrm{ml}$ of water. After removal of pollen, we passed the bee through a drying process with an absorbent paper, and we marked the thorax with a non-toxic paint (Posca ${ }^{\circledR}$ - Tokyo, Japan) before being released again (to avoid collection of the same speciemen). Then, we completed the remaining material in the falcon tube with $6 \mathrm{~mL}$ of absolute alcohol and left for at least $24 \mathrm{~h}$. 
We observed the females in the flowers to verify if they were collecting nectar, pollen or oil. With these observations was possible to associate the pollen analysis with the floral resource collected in each plant species.

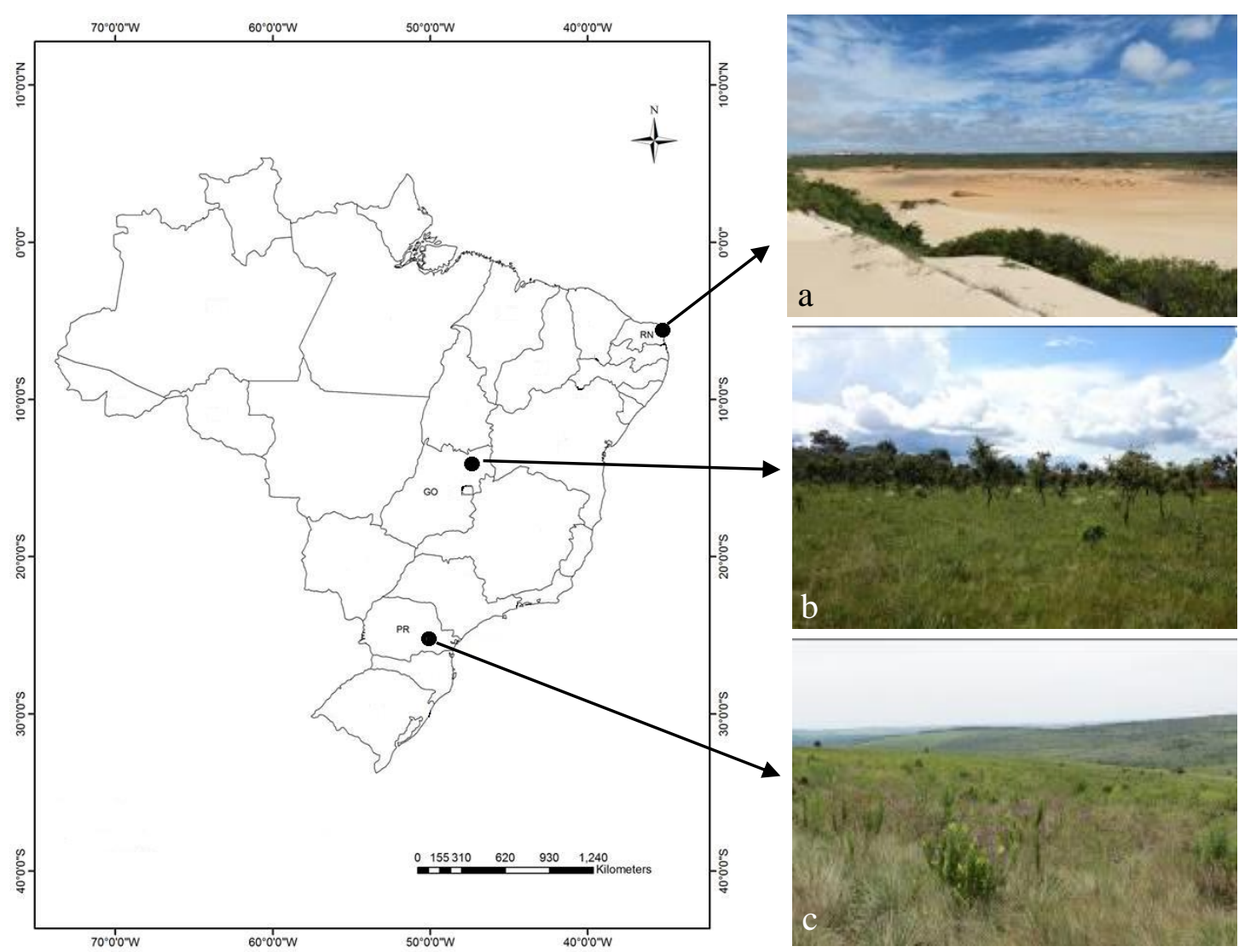

Fig. 1 Study areas where the Centris burgdorfi females were founded: a) a region of costal dunes and restinga vegetation known as the "Deserto dos Anjos" in the Northeast of Brazil (RN); b) a Cerrado in the Center-west region of Brazil in the park "Chapada dos Veadeiros" (GO) and c) altitudinal field in Southern Brazil, inside the "Parque Estadual de Vila Velha" (RN)

\section{Pollen analysis}

We centrifuged pollen material at $2000 \mathrm{rpm}$ for $10 \mathrm{~min}$, discarded ethanol, added $4 \mathrm{~mL}$ of glacial acetic acid and left samples to stand for $24 \mathrm{~h}$. Subsequently, we acetolysed the pollen grains (Erdtman 1960), embedded them in Kisser gelatin and sealed slides with 
transparent varnish. We identified pollen grains to the finest taxonomic level possible, and documented the frequencies of occurrence of each taxa per slide. To enable more accurate identification of the pollen taken from bee samples, we also made references slides of the flowering species in each sampling area by taking the anthers and subjected them to acetolysis following Silva et al. (2014). We also used the pollen collection present in the RCPol - Rede de Catálogos Polínicos online (www.rcpol.org.br) to identify through comparation the plant species or pollen type.

\section{Data analysis}

To evaluate which plants the bees use, we made qualitative analysis, identifying the plant species found in the samples. Afterwards we made the quantitative analysis assessed the importance of each plant species used by the bees. For that, we examined the first 400 pollen grains in each sample, as suggested by Montero and Tormo (1990). Then, we calculated the percentage of each pollen type in a sample and classified the pollen grains per Maurizio and Louveaux (1965): dominant pollen (>45\% of all grains counted in each sample), accessory pollen (15 to $45 \%$ ), important isolated pollen ( 3 to $15 \%)$ and occasional isolated pollen $(<3 \%)$.

To evaluate the importance of each plant species according the volume of the pollen grains, we calculated an estimated volume for each pollen type by application of the pollen grain measurements to the volumetric formulae [Ellipsoid $=4\left(\pi \mathrm{e}^{2} \mathrm{p}\right) / 3$ and sphere $=4\left(\pi \mathrm{e}^{3}\right) / 3$ ]. The data were collected using 15 grain (randomly encountered on the slides) of each species in equatorial view, where we obtain the mean value of the polar radius (p) and equatorial radius (e). Pollen types with a few grains in the slides, insufficient to be measured, did not have their volumes calculated.

From the proportion data, we evaluated the trophic niche using the index of Shannon (1948) $\left(H^{\prime}\right)$. A Hutchinson $\mathrm{t}$ test was performed to verify if there are significant differences between the values of the Shannon divesity indices between the three areas. To check the uniformity in the samples, we used the index of Pielou (1966) $\left(J^{\prime}\right)$, and to analyze the dominance we applied the index of Berger-Parker (Magurran 2004) (D). Analyses of diet breadth were performed using the statistical software PAST

2.17c (Hammer et al. 2001). We also analyzed the index of interindividual niche variation $(E)$ in the network that was achieved using the software Dieta 1.0 (Araujo et al. 2008). We made the representation of the trophic interaction network as bipartite 
graphs (Dormann et al. 2008) using the bipartite package for $\mathrm{R}$ Development Core Team (2012). We drawn weighted graphs in Pajek 4.10 (Batagelj and Mrvar 1998) using the "Kamada-Kawai free" method, which makes more evident the subgroups and the centrality of each vertex.

\section{Results}

We identified 41 plant species belonging to 21 genera and 18 families used in the diet of C. burgdorfi (Table 1) in the 3 localities. In Natal we identified eight plant species and Chamaecrista (Leg.-Caesalpinioideae) seem to be the main source of pollen, with a high frequency of occurrence the slides (Chamaecrista hispidula (Vahl.) Irwin \& Barneby $=42.61 \%$ and Chamaecrista flexuosa (L.) Greene $=37.34 \%$, accounting together almost $80 \%$ of the pollen grains in the samples). Cuphea flava Spreng. (Lythraceae) is the major source of nectar, being represented by $17.05 \%$ in the samples. The source of floral oil came exclusively from Krameria tomentosa A. St.-Hil. (Krameriaceae). The number of pollen grains of this plant in the samples is low $(1,45 \%)$, but constant in each slide $(94,74 \%)$.

In Cavalcante we identified 19 species belonging to 16 genera and 15 families. The main source of pollen present in the samples was Microlicia crypitandra Naudin (Melastomataceae) (32.39\% of all pollen grains). Krameria grandiflora A. St.-Hil. was the main source of floral oil, and constant in the slides (91\%). The major source of nectar came from Lepidaploa rufogrisea (A.St.-Hil.) H.Rob. (Asteraceae) (3.05\%) and a Bromeliaceae that was not identified (15.08\%).

In Ponta Grossa we identified 14 plant species belonging to six genera and seven families. The main source of pollen present in the samples were Chamaecrista sp.1 (45.95\%) and Angelonia integerrima Spreng. (Plantaginaceae) (40.37\%). This last species is the source of floral oil, and with our observations in the field we verified that the females search actively more for the oil. Pollen probably is getting into their body passively. Lessingianthus grandiflorus (Less.) H. Rob (Asteraceae) (11.17\% of all pollen grains) appear as the main source of nectar.

The genera Chamaecrista and Mimosa were the only pollen source shared by the bees from the three sites (Fig. 2). We identified at least 5 species of Chamaecrista (Table 1) and in the localities of Natal (the 2 species together) and Ponta Grossa they were dominants pollen grains. 
Table 1. Proportion of each plant species identified in the body of Centris burgdorfi females in Brazil. $\mathrm{RN}=$ sand dunes, Natal (Northeastern); $\mathrm{GO}=$ Cerrado, Cavalcante (Center-west); $\mathrm{PR}=$ altitudinal field, Ponta Grossa (Southern). RPP $=$ Resource present in the plant: $\mathrm{O}=$ oil, $\mathrm{P}=$ pollen e $\mathrm{N}=$ nectar. $\mathrm{MIGV}=$ mean individual grain volume. $\mathrm{TPV}=$ Total pollen volume by taxon. $\% \mathrm{n}=$ contribution in number of grains counted. \%vn= estimated volumetric contribution

\begin{tabular}{|c|c|c|c|c|c|c|c|}
\hline \multirow[t]{3}{*}{ Species/Pollen type } & \multirow[t]{3}{*}{$\mathbf{R P P}$} & \multirow{3}{*}{$\begin{array}{l}\text { MIGV } \\
\left(\mu \mathrm{m}^{3}\right)\end{array}$} & \multirow{3}{*}{$\begin{array}{c}\text { TPV } \\
\left(\mu \mathrm{m}^{3}\right)\end{array}$} & \multicolumn{4}{|c|}{ Percentage contribuition } \\
\hline & & & & \multicolumn{3}{|c|}{$\% \mathbf{n}$} & \multirow[t]{2}{*}{$\% \mathbf{v n}$} \\
\hline & & & & $\mathbf{R N}$ & GO & PR & \\
\hline \multicolumn{8}{|l|}{ Amarantaceae } \\
\hline sp. 1 & - & - & - & - & - & 0.02 & - \\
\hline \multicolumn{8}{|l|}{ Anacardiaceae } \\
\hline Anacardium sp. & $\mathrm{PN}$ & 224550.79 & 3143711.08 & 0.07 & - & - & 0.46 \\
\hline \multicolumn{8}{|l|}{ Asteraceae } \\
\hline Lepidaploa rufogrisea (A.St.-Hil.) H.Rob. & $\mathrm{PN}$ & 60924.99 & 37164242.60 & - & 3.05 & - & 6.04 \\
\hline Lessingianthus grandiflorus (Less.) H. Rob. & $\mathrm{PN}$ & 44216.88 & 98780518.56 & - & - & 11.17 & 24.87 \\
\hline Senecio sp. & $\mathrm{PN}$ & 13800.69 & 5064854.47 & - & 1.84 & - & 0.82 \\
\hline sp.1 & - & - & - & - & - & 0.09 & - \\
\hline Vernonia sp.1 & - & 37912.75 & 113738.24 & - & 0.02 & - & 0.02 \\
\hline Vernonia sp.2 & $\mathrm{PN}$ & 93488.61 & 1028374.72 & 0.06 & - & - & 0.15 \\
\hline Bromeliaceae & & & & - & - & - & \\
\hline sp.1 & - & 103499.93 & 312155795.75 & - & 15.08 & - & 50.73 \\
\hline Convolvulaceae & & & & & & - & \\
\hline Merremia sp. & - & - & - & - & 0.01 & - & - \\
\hline \multicolumn{8}{|l|}{ Iridaceae } \\
\hline Sisyrinchium vaginatum Spreng & $\mathrm{P}$ & 27823.74 & 72202615.70 & - & 12.975 & - & 11.73 \\
\hline \multicolumn{8}{|l|}{ Krameriaceae } \\
\hline Krameria grandiflora A. St.-Hil. & $\mathrm{PO}$ & 19509.29 & 4760267.44 & - & 1.22 & - & 0.77 \\
\hline Krameria tomentosa A. St.-Hil. & $\mathrm{PO}$ & 20816.66 & 6036830.60 & 1.45 & - & - & 0.87 \\
\hline \multicolumn{8}{|l|}{ Lamiaceae } \\
\hline Hyptis pachyphylla Epling & $\mathrm{PN}$ & 19106.21 & 14215020.71 & - & 3.72 & - & 2.31 \\
\hline \multicolumn{8}{|l|}{ Leg.-Caesalpinioideae } \\
\hline $\begin{array}{l}\text { Chamaecrista flexuosa (L.) Greene } \\
\text { Chamaecrista hispidula (Vahl.) Irwin \& }\end{array}$ & $\mathrm{P}$ & 62194.79 & 464408498.73 & 37.34 & - & - & 67.28 \\
\hline Barneby & $\mathrm{P}$ & 23160.31 & 197349001.90 & 42.61 & - & - & 28.59 \\
\hline Chamaecrista sp.1 & $\mathrm{P}$ & 29027.57 & 266734359.41 & - & - & 45.95 & 67.15 \\
\hline Chamaecrista $\mathrm{sp} .2$ & $\mathrm{P}$ & - & - & - & - & 0.03 & - \\
\hline Chamaecrista sp.3 & $\mathrm{P}$ & 34865.04 & 50972690.89 & - & 7.31 & - & 8.28 \\
\hline Mimosa daleoides Benth. & & 618.59 & 81653.81 & - & - & 0.66 & 0.02 \\
\hline Mimosa sp.1 & $\mathrm{PN}$ & - & - & 1.39 & - & - & - \\
\hline Mimosa manidea Barneby & $\mathrm{PN}$ & 2082.54 & 808026.37 & - & 1.94 & - & 0.13 \\
\hline Senna sp.1 & $\mathrm{P}$ & 20430.60 & 408611.92 & - & & 0.1 & 0.10 \\
\hline Senna velutina (Vogel) H.S. Irwin \& Barneby & $\mathrm{P}$ & 39522.34 & 14702308.82 & & 1.86 & & 2.39 \\
\hline
\end{tabular}




\begin{tabular}{|c|c|c|c|c|c|c|c|}
\hline \multirow[t]{3}{*}{ Species/Pollen type } & \multirow[t]{3}{*}{$\mathbf{R P P}$} & \multirow{3}{*}{$\begin{array}{l}\text { MIGV } \\
\left(\mu \mathrm{m}^{3}\right)\end{array}$} & \multirow{3}{*}{$\begin{array}{c}\text { TPV } \\
\left(\mu \mathrm{m}^{3}\right)\end{array}$} & \multicolumn{4}{|c|}{ Percentage contribuition } \\
\hline & & & & \multicolumn{3}{|c|}{$\% \mathbf{n}$} & \multirow[t]{2}{*}{$\%$ vn } \\
\hline & & & & $\mathbf{R N}$ & GO & PR & \\
\hline Leg.-Papilionoideae & & & & - & - & & \\
\hline Centrosema brasilianum (L.) Benth & PN & 79358.88 & 793588.78 & 0.05 & - & - & 0.11 \\
\hline Centrosema virginianum (L.) Benth & PN & 76586.47 & 23052528.74 & - & - & 3.61 & 5.80 \\
\hline Stylosanthes sp.1 & PN & - & - & - & 0.01 & - & - \\
\hline \multicolumn{8}{|l|}{ Lythraceae } \\
\hline Cuphea flava Spreng. & PN & 5146.28 & 17548829.27 & 17.05 & - & - & 2.54 \\
\hline Cuphea linarioides Cham. \& Schlecht & $\mathrm{PN}$ & - & - & - & - & 0.07 & - \\
\hline Diplossodon sp. & & 248297.52 & 32526975.05 & - & 0.65 & - & 5.29 \\
\hline \multicolumn{8}{|l|}{ Malphiguiaceae } \\
\hline Byrsonima sp. & $\mathrm{PO}$ & 2729.92 & 32759.00 & - & 0.06 & - & 0.01 \\
\hline \multicolumn{8}{|l|}{ Melastomataceae } \\
\hline Microlicia cryptandra Naudin & $\mathrm{P}$ & 5833.12 & 56849542.87 & - & 48.73 & - & 9.24 \\
\hline \multicolumn{8}{|l|}{ Plantaginaceae } \\
\hline Angelonia integerrima Spreng. & $\mathrm{PO}$ & 1007.50 & 8134534.69 & - & - & 40.37 & 2.05 \\
\hline \multicolumn{8}{|l|}{ Poaceae } \\
\hline sp.1 & - & - & - & - & 0.02 & - & - \\
\hline \multicolumn{8}{|l|}{ Rubiaceae } \\
\hline Borreria sp. & PN & 45926.46 & 13686085.37 & - & 1.49 & - & 2.22 \\
\hline \multicolumn{8}{|l|}{ Vockysiaceae } \\
\hline Vockysia sp. & $\mathrm{PN}$ & 33657.95 & 67315.89 & - & 0.01 & - & 0.01 \\
\hline Indeterminate- 2 & - & - & - & - & 0.01 & - & - \\
\hline Indeterminate-3 & - & - & - & - & - & 0.03 & - \\
\hline Indeterminate- 4 & - & - & - & - & - & 0.02 & - \\
\hline Indeterminate- 5 & - & - & - & - & - & 0.01 & - \\
\hline Indeterminate- 6 & - & - & - & - & - & 0.01 & - \\
\hline$S$ & - & & & 8 & 19 & 14 & \\
\hline$H^{\prime}$ & - & & & 1.17 & 1.71 & 1.09 & \\
\hline$J^{\prime}$ & - & & & 0.56 & 0.58 & 0.41 & \\
\hline$D$ & - & & & 0.43 & 0.49 & 0.46 & \\
\hline$E$ & - & & & 0.4 & 0.6 & 0.4 & \\
\hline
\end{tabular}

$S=$ richness of species, $H^{\prime}=$ index of Shanonn-Wiener, $J^{\prime}=$ index of Pielou, $D=$ index of Berger-Parker, $E=$ interindividual niche variation. 


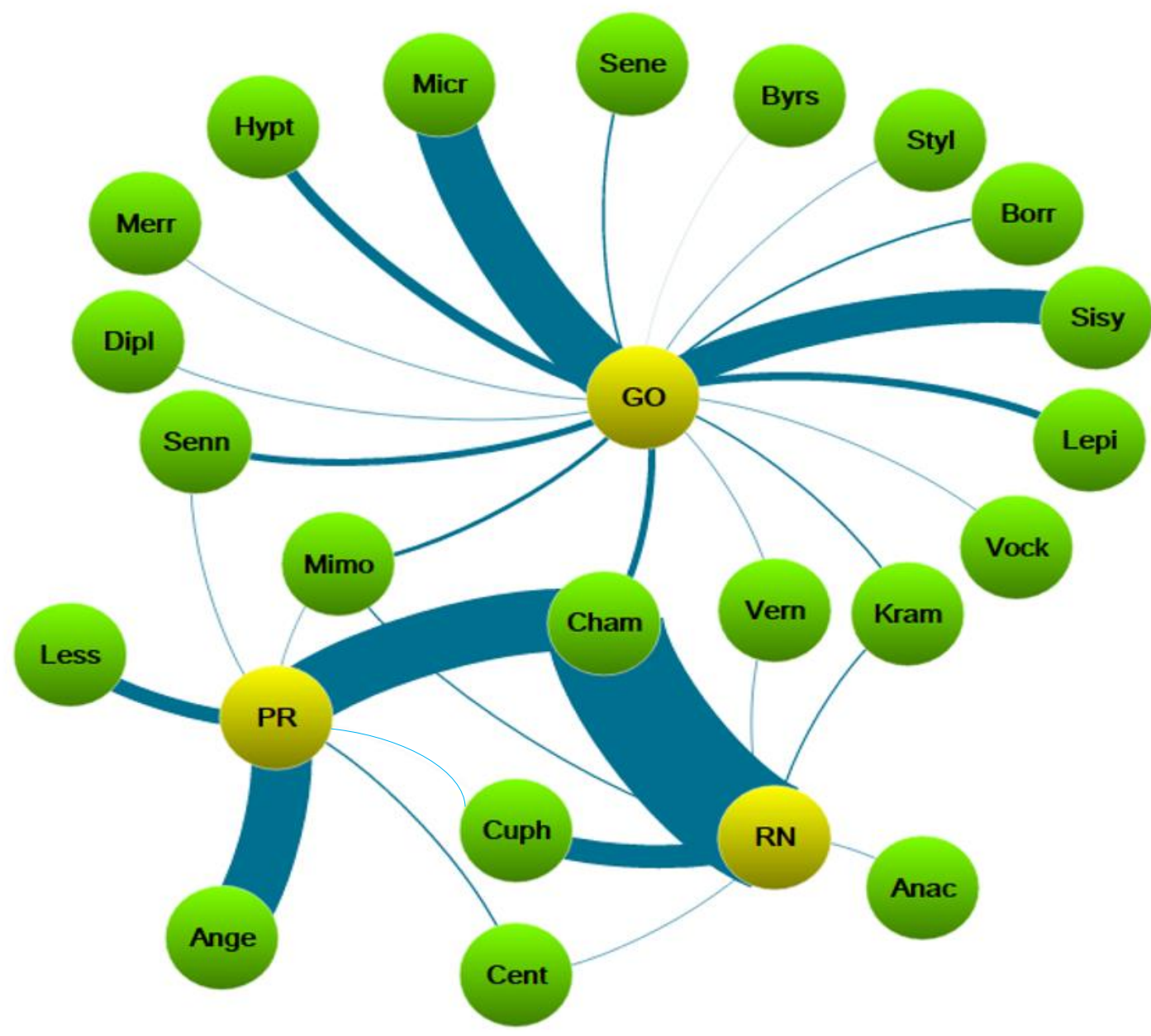

Figure 2. Weighted graphs showing the study sites $(\mathrm{GO}=$ Cavalcante, $P R=$ Ponta Grossa and $\mathrm{RN}=$ Natal) and the genus of plants found in a body of Centris burgdorfi. Line width is proportional to the frequency of pollen grains in the diet. Anac= Anacardium $;$ Ange $=$ Angelonia $;$ Borr $=$ Borreria $;$ Byrs $=$ Byrsonima $;$ Cent $=$ Centrosema $;$ Cham $=$ Chamaecrista $;$ Cuph $=$ Cuphea $;$ Dipl= Diplossodon $;$ Hypy= Hyptis; Kram= Krameria; Lepi $=$ Lepidaploa; Less $=$ Lessingianthus; Micr $=$ Microlicia $; \mathrm{Mimo}=$ Mimosa $;$ Sene= Senecio $;$ Senn= Senna $;$ Sisy= Sisyrinchium $;$ Styl= Stylosanthes $;$ Merr $=$ Merremia $;$ Vern= Vernonia $;$ Vock= Vockysea . 
Concerned to the diversity indexes in Cavalcante, where the richness was bigger (19 pollen types), the diversity of Shannon was higher $\left(H^{\prime}=1.71\right)$ comparing to Natal $\left(H^{\prime}=1.17\right)$ and Ponta Grossa $\left(H^{\prime}=1.09\right)$, as well as interindividual niche variation $\left(E_{\text {Cavalcante }}=0.6\right.$; $E_{\text {Ponta Grossa }}$ and $\left.E_{\text {Natal }}=0.4\right)$. The eveness was lower in Ponta Grossa $(J=0.41)$ than Cavalcante and Natal $\left(J_{\text {Cavalcante }}=0.58\right.$ and $\left.J_{\text {Natal }}=0.56\right)$. The dominace index was similar between the three sites $\left(D_{\text {Cavalcante }}=0.49 ; D_{\text {Natal }}=0.43 ; D_{\text {Ponta Grossa }}=0.46\right.$ ) (Table 1). The Hutchinson t-test revealed that all areas showed significantly different index of diversity $(\mathrm{p}<0.05)$.

In the bipartite networks constructed with the proportional number of pollen types found in each sample and each locality it is possible to observe the dominance of Chamaecrista in Natal and Ponta Grossa (Fig. 3 and Fig. 5). Chamaecrista hispidula and $C$. flexuosa were the main pollen grains, dominant in 44 out of 50 samples (22 each) collected in Natal (Fig. 3). In Ponta Grossa the dominance of Chamaecrista sp.1 is shared with Angelonia integerrima (28 and 18 samples respectively) and both were accessory in others 10 or 19 samples, respectively (Fig. 5). In Cavalcante we observe clearly that more species are used in the diet of C. burgdorfi. Microlicia crypitandra was dominant in 23 out of the 50 samples, and accessory in other 10. One species of Bromeliaceae (which could be also source of nectar) and Sisyrinchium vaginatum Spreng have dominance of pollen grains in 8 samples each (Fig. 4).

The mean pollen grain volumes resalted the importance of Chamaecrista in the samples in Natal and Ponta Grossa and also Bromeliaceae in Cavalcante. The smallest pollen grain of the plants as Angelonia and Microlicia makes these species appear in a smaller proportion in each sample (Table 1). 


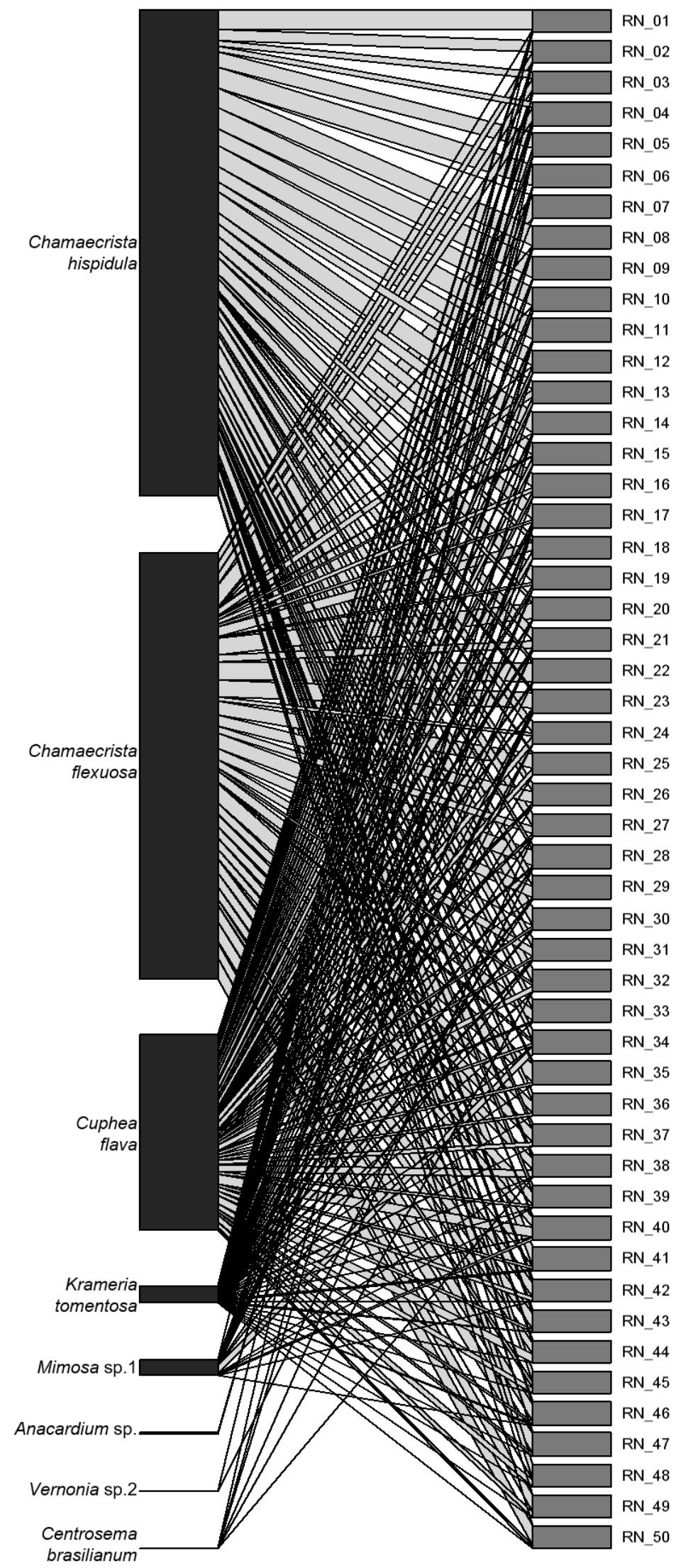

Figure 3. Individual diet of Centris burgdorfi in the sand dunes region (RN) in Northeast, Brazil, collected in April 2011 (RN_01 to RN_15) and April and May 2014 (RN_16 to RN_50). 


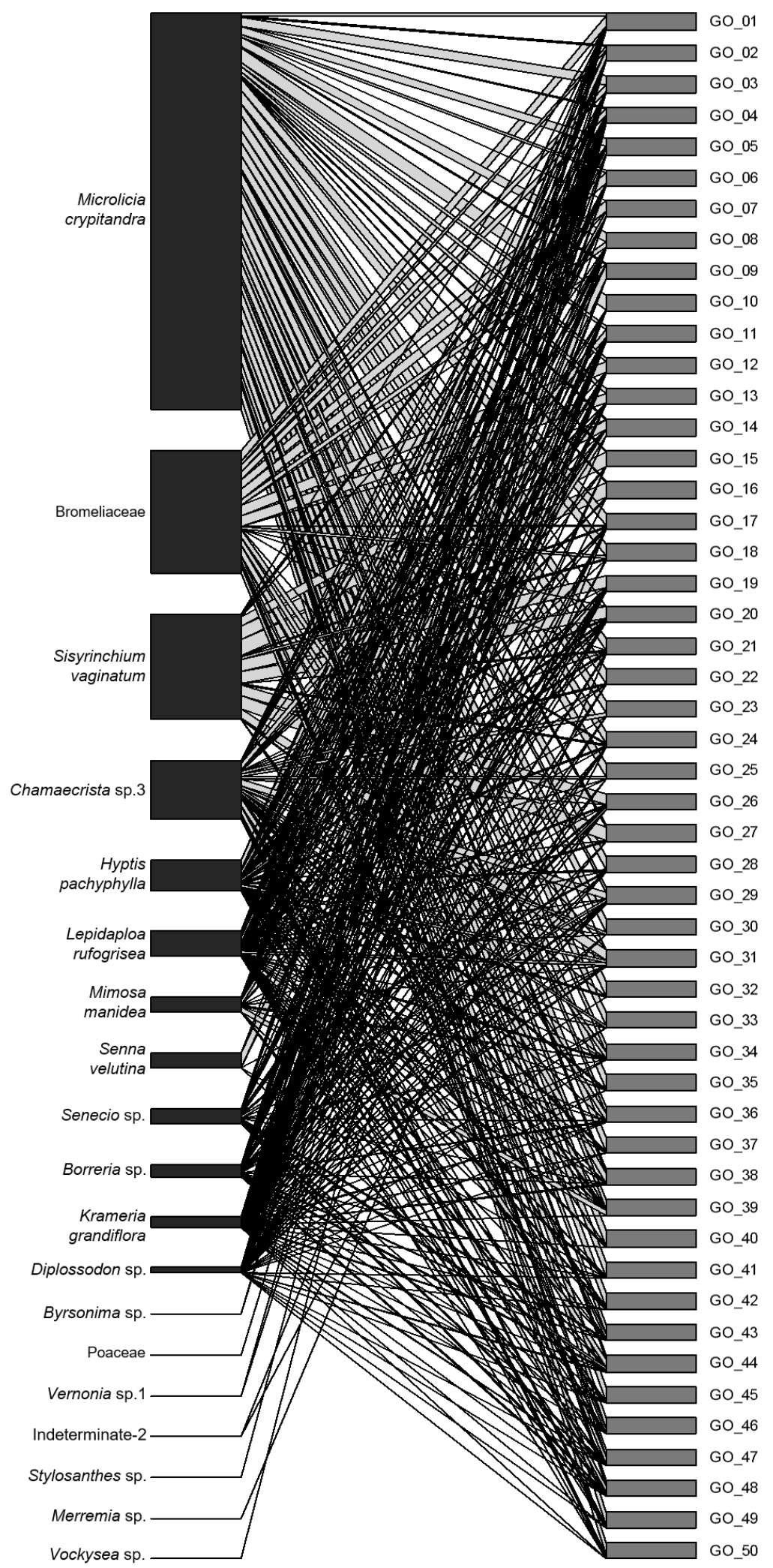

Figure 4. Individual diet of Centris burgdorfi in a Cerrado area in Cavalcante, GO (Center-west) Brazil, collected in April 2015 (GO_01 to GO_22) and April 2017 (GO_23 to GO_50). 


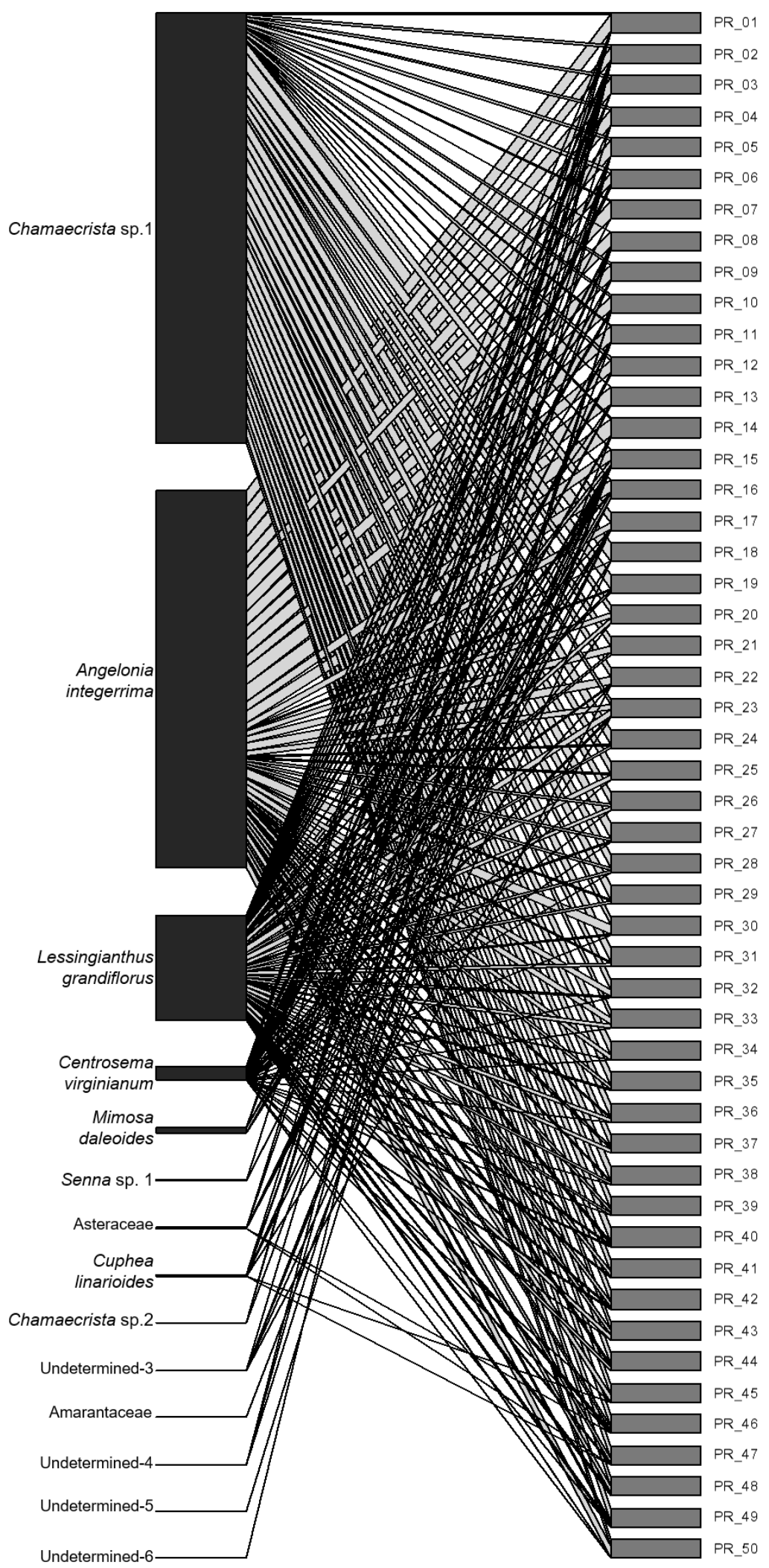

Figure 5. Individual diet of Centris burgdorfi in an altitudinal field (PR) in Southern, Brazil collected in December 2015 (PR_01 to PR_18) and November 2016 (PR_19 to PR_50). 


\section{Discussion}

Centris burgdorfi proved to be locally specialized but generalist when we evaluated spatially. We did not observe any plant species shared among the areas, just a few genera, which is expected since the difference (mainly in relation to the type of vegetation) among the study areas. Although a large amount of pollen types found in samples of the three areas it is clear the presence of plants of the genus Chamaecrista as one of the preferred sources in the diet of the C. burgdorfi. Pollen of this genus was very common in the samples of the three locations, even in the case of females belonging to distinct study areas. Chamaecrista flowers are important pollen sources for bees of the genus Centris (Aguiar 2003), which are able to collect pollen through vibration of the anthers (Buchmann 1985). Therefore, are commonly found in the results of studies about trophic niche of Centris (e.g. Gaglianone 2001; Dórea et al. 2009, 2010a, 2010b; Santos et al. 2013). Nutritionally, plants with poricidal anthers tend to have very protein-rich pollen (Rolston et al. 2000) which can be used as an important resource for the bees in both larval and adult diet.

The higher diversity of the plants used by females of $C$. burgdorfi was in the Cerrado (Cavalcante). This fitofisionomy is certainly richer when compared with dunes vegetation and altitudinal fields. The largest, richest, and possibly most threatened tropical savanna in the world is the Cerrado, a large region that occupies the center of South America (Silva and Bates 2002). The higher evenness observed in Cavalcante shows that the females are using the plants species uniformly, without the dominance of any species in the network. Also, the higher interindividual niche variation shows that each female is collecting resources from different plants inside the local population. On the other hand, in the costal dunes (Natal) we observed a lower richness when compared with the two other sites and a low interindividual niche variation. The dune habitat is characterized by sparse plant cover (Calliari and Klein 1993) and this is reflected in a restrict number of plants available for the visitation of bees.

The parameters observed in Natal added to a great dominance in the network caused by three species of plants (Chamaecrista hispidula, C. flexuosa and Cuphea flava) is worrying if we consider that the plants used by females occurs on the top of the touristic dunes, route of dozens of off-road vehicles daily. The physical development of the tourism on costal environments contribute to substantial, often irreversible, environmental degradation (Davenport and Davenport 2006). The impacts result in 
changes to the vegetation including loss of height, biomass, reproductive structures, reduction in cover, increased litter, damage to seedlings and change in species composition (Pickering and Hill 2007). Females of $C$. burgdorfi have a specific nesting site, only using petrified dunes at the same place that the females collect resources (Sabino et al. in prep.). Preservation policies are needed so that there was no loss of species with tourist activities.

The presence of pollen grain species of Krameria in Natal and Cavalcante samples demonstrates that females use plants of this genus as a source of floral oil at these sites. Although Centris bees are commonly known as generalists in floral oil source (Buchmann 1987), the analysis showed a high fidelity to only one species. In both places, there are species of Byrsonima (Malpighiaceae) flowered at the same time, but Byrsonima only appeared as occasional isolated pollen $(<3 \%)$ in Cavalcante and none in Natal. The genus Krameria has a distribution generally associated to arid and semi-arid locations of the Americas (Simpson 1982) and does not occur in part of the Southestern and all the South of Brazil. In the absence of Krameria in Ponta Grossa $C$. burgdorfi is using Angelonia integerrima as floral oil source. Females of Centris (Paracentris) subgenus have pronounced changes in the common pattern to most fourlegged Centris. The modification of this pattern (called "fourlegged with modifications") found in $15 \%$ of Centris species, is characterized by the giant seta with a slightly rounded apex, as seen in C. burgdorfi (Taniguchi 2010). These modifications are often related to the collection of floral oil in plants with trichromatic elaiophores, easier to access than the epithelial (Vogel 1974; Simpson et al. 1990; Cocucci 1991). In other words, plants possessing the trichromatic pattern would be preferably used as a source of oil. In fact, there seems to be an association between C. burgdorfi and Angelonia. Martins et al. (2013) also recorded this bee species collecting floral oil in Angelonia eriostachys Benth. and Angelonia goyazensis Benth in an altitudinal field in Southeastern Brazil.

Although the association with plants of the family Plantaginaceae, the use of Krameria as a source of floral oil in Natal and Cavalcante, demonstrates that the oilcollector apparatus does not restrict the species of bees to one or another type of elaiophores as previously proposed by Simpson et al. (1990). Carneiro et al. (2015) observed Centris hyptidis, previous associated with trichomatic elaiophores, collecting floral oil in $K$. tomentosa in areas with no Plantaginaceae. Centris (Heterocentris) analis is known for collecting floral oil both: Malpighiaceae (Oliveira and Schlindwein 
2009) and Plantaginaceae (Martins et al. 2013). As the recent debates on floral syndromes and pollinators (see the review of Rosas-Guerrero et al. 2014) a restricted connection between the oil-collectors apparatuses in bees and the type of elaiophore used, needs caution.

The association between Centris bees and plants of the family Malpighiaceae is widely known (Vogel 1990; Sigrist and Sazima 2004; Bezerra et al. 2009; Mello et al. 2013; Oliveira et al. 2013), being the result of a convergence more than 90 Ma (Martins et al. 2014). Although molecular studies suggest that Centridini tribe is old (Renner and Schaefer 2010), Centris (Paracentris) burgdorfi belongs to a more recent lineage (Martins and Melo 2015). The preference for Krameria may have arisen in order to avoid competition with bees long associated with Malpighiaceae, since both Krameriaceae and Plantaginaceae are also newer groups (Renner and Schaefer 2010).

It would be necessary to search for places where the three components occur simultaneously (C. burgdorfi, Krameria e Angelonia) to assess if there is preference for a plant species, or type of elaiophore. This scenario is difficult since while Krameriaceae occurs in more xeric sites (Simpson 1982), the species of Plantaginaceae are usually linked to altitude sites (Martins et al. 2013).

The volumetric analysis of pollen ressalted the importance of plants that have large pollen grains. Tasei (1973) affirmed that the frequencies obtained across the number of grains counted in the slides may not represent the real contribution due to the great variation in size of grains among plant species. Dispite the importance of volumetric analysis that was demonstrated by some pollen studies (e.g. Buchmann and O'rourke 1991; Silveira 1991) we have to be careful when we analyze the volumetric corrections of proportions. The size of the pollen grain is not related to the amount of protein present in the pollen (see Roulston et al. 2000). Small pollen grains as Angelonia and Microlicia may have more importance for the bees than simply shown by volumetric analysis. To acess the real importance of each pollen type, it is necessary to use information such as the frequency of the pollen grain in the samples, the volume and quantity of protein of each grain.

The study showed that $C$. burgdorfi has a plasticity of the trophic niche among distinct phytoregions in Brazil (costal dunes, Cerrado and altitudinal field). No plant species was shared among the three sites studied. The specie is specialized locally in the floral oil source showing plasticity between trichomatic and epithelial elaiophores. This 
plasticity of the trophic niche and of the type of elaiophore allow the species to have a wide geographical distribution even where the preferred resource is not available.

Acknowledgments The authors are grateful to Paulo Roberto de Castro for the help and all support in the field work and Ana Carolina Oliveira da Silva and Elisa Pereira Queiroz for making all the measurements of the pollen grains. We also thank to Astrid Kleinert, Liz Nichols and Felipe Vivallo for comments and suggestions in the manuscript. The research was supported by Fundação de Amparo à Pesquisa do Estado de São Paulo (FAPESP) and Coordenação de Aperfeiçoamento de Pessoal de Nível Superior (CAPES).

\section{References}

Aguiar CML (2003) Flower visits of Centris bees (Hymenoptera: Apidae) in an area of caatinga (Bahia, Brazil). Stud Neotrop Fauna Environ 38(1): 41-45

Aleixo KP, Faria LB, Garófalo CA, Fonseca VLI, Silva CI (2013) Pollen collected and foraging activities of Frieseomelitta varia (Lepeletier) (Hymenoptera: Apidae) in an urban landscape. Sociobiology 60(3): 266-276

Alves-dos-Santos I., Machado IC, Gaglianone MC (2007) História natural das abelhas coletoras de óleo. Oecol Bras 11(4): 544-557

Araujo MS, Guimaraes PR, Svanback R, Pinheiro A, Guimaraes P, Reis SF, Bolnick DI (2008) Network analysis reveals contrasting effects of intraspecific competitions on individual vs. population diets. Ecology 89: 1981-1993

Batagelj V, Mrvar A (1998) Pajek-program for large network analysis. Connections 21(2): 47-57

Bearhop S, Adams CE, Waldron S, Fuller RA, MacLeod H (2004) Determining trophic niche width: a novel approach using stable isotope analysis. J Anim Ecol 73(5): $1007-1012$

Bezerra ES, Lopes AV, Machado IC (2009) Biologia reprodutiva de Byrsonima gardnerana A. Juss. (Malpighiaceae) e interações com abelhas Centris (Centridini) no Nordeste do Brasil. Revista Brasil Bot 32(1): 95-108

Brown JH (1984) On the relationship between abundance and distribution of species. Am Nat 124: 255-279 
Buchmann SL (1985) Bees use vibration to aid pollen collection from non-poricidal flowers. J Kans Entomol Soc 58(3): 517-525

(1987) The ecology of oil flowers and their bees. Ann Rev Ecol Syst 18: 343369

Buchmann SL, O'rourke MK (1991) Importance of pollen grain volumes for calculating bee diets. Grana 30(3-4): 591-595

Calliari LJ, Klein ADF (1993) Características morfodinâmicas e sedimentológicas das praias oceânicas entre Rio Grande e Chuí, RS. Pesquisas 20(1): 48-56

Cane JH, Sipes S (2006) Characterizing floral specialization by bees: analytical methods and a revised lexicon for oligolecty. In: Waser NM, Ollerton J (eds) Plant-Pollinator Interactions, from Specialization to Generalization. University of Chicago Press, Chicago, IL, pp 99-122

Cardoso MRD, Marcuzzo FFN, Barros JR (2014) Classificação Climática de KöppenGeiger para o Estado de Goiás e o Distrito Federal. Act Geog 8(16): 40-55

Carneiro LT, Aguiar AJC, Martins CF, Machado IC, Alves-dos-Santos I (2015) Krameria tomentosa oil flowers and their pollinators: Bees specialized on trichome elaiophores exploit its epithelial oil glands. Flora 215: 1-8

Cocucci A (1991) Pollination biology of Nierembergia (Solanaceae). Plant Syst Evol 174: $17-35$

Davenport J, Davenport JL (2006) The impact of tourism and personal leisure transport on coastal environments: a review. Estuar Coast Shelf Sci 67(1): 280-292

Dórea MC, Santos FAR, Lima LCL, Figueroa LER (2009) Análise polínica do resíduo pós-emergência de ninhos de Centris tarsata Smith (Hymenoptera: Apidae, Centridini). Neotrop Entomol 38(2): 197-202

Dórea MC, Aguiar CM, Figueroa LER, Lima LCL, Santos FAR (2010a) Pollen residues in nests of Centris tarsata Smith (Hymenoptera, Apidae, Centridini) in a tropical semiarid area in NE Brazil. Apidologie 41(5): 557-567

(2010b) Residual pollen in nests of Centris analis (Hymenopera, Apidae, Centridini) in an area of Caatinga vegetation from Brazil. Oecol Aust 14(1): $232-237$

Dormann CF, Gruber B, Fründ J (2008) Introducing the bipartite package: analyzing ecological networks. R News 8: 8-11

Erdtman G (1960) The acetolized method. A revised description. Svensk Bot Tidskrift 54: $561-564$ 
Gaglianone MC (2001) Nidificação e forrageamento de Centris (Ptilotopus) scopipes Friese (Hymenoptera, Apidae). Rev Bras Zool 18 (Supl. 1): 107-117

Gonçalves RB, Melo GAR (2005) A comunidade de abelhas (Hymenoptera, Apidae s.l) em uma área restrita de campo natural no Parque Estadual de Vila Velha, Paraná: diversidade, fenologia e fontes florais de alimento. Rev Bras Entomol 49(4): 557-571

Hammer $\emptyset$, Harper DAT, Ryan PD (2001) PAST: Paleontological statistics software package for education and data analysis. Palaeontologia Electronica 4 (1): 9. Available at http://palaeo-electronica.org/2001_1/past/issue1_01.htm.

Herrera J (1988) Pollination relationships in southern Spanish Mediterranean shrublands. J Ecol 76: 274-87

Holt RD (2009) Bringing the Hutchinsonian niche into the 21st century: ecological and evolutionary perspectives. PNAS 106(Supplement 2): 19659-19665

INMET/UFRN (2002) Instituto Nacional de Meteorologia/UFRN. Boletins Climatológicos: anos 1984 a Maio/2002. Estação Climatológica Principal. Natal

Kearns CA, Inouye DW, Waser NM (1998) Endangered mutualisms: the conservation of plant-pollinator interactions. Annu Rev Ecol Evol Syst 29(1): 83-112

Köppen W (1900) Versuch einer Klassifikation der Klimate, vorzugsweise nach ihren Beziehungen zur Pflanzenwelt. - Geogr Zeitschr 6: 593-611, 657-679

Magurran AE (2004) Measuring Biological Diversity. Blackwell Science, Oxford.

Martins AC, Aguiar AJC, Alves-dos-Santos I (2013) Interaction between oil-collecting bees and seven species of Plantaginaceae. Flora 208(7): 401-411

Martins AC, Melo GAR, Renner SS (2014) The corbiculate bees arose from New World oil-collecting bees: implications for the origin of pollen baskets. Mol Phylogenet Evol 80: 88-94

Martins AC, Melo GAR (2015) The New World oil-collecting bees Centris and Epicharis (Hymenoptera, Apidae): molecular phylogeny and biogeographic history. Zool Scripta 1-12

Maurizio A, Louveaux J (1965) Pollens de Plantes Mellifères d'Europe. Union des groupements apicoles français, Paris.

Mello MAR, Bezerra ELS, Machado IC (2013) Functional Roles of Centridini Oil Bees and Malpighiaceae Oil Flowers in Biome-wide Pollination Networks. Biotropica 45(1): $45-53$ 
Michener CD (1974) The Social Behavior of the Bees. Harvard University Press. Cambridge, Mass

Michener CD (1979) Biogeography of the bees. Ann Missouri Bot Gard 66 (3): 277-347

Minckley RL, Roulston TH (2006) Incidental mutualisms and pollen specialization among bees. In: Waser NM, Ollerton J. Plant-pollination interactions: from specialization to generalization. Chicago: University Chicago Press, pp 69-98

Montero I, Tormo R (1990) Análisis polínnico de mieles de cuatro zonas montanhosas de Extremadura. Nacl Asoc Palinol Leng Esp 5: 71-78

Neff JL, Simpson BB (1981). Oil-collecting structures in the Anthophoridae (Hymenoptera): Morphology, function, and use in systematics. J Kansas Entomol Soc 54(1): 95-123

Oliveira GA, Aguiar CML, Silva M, Gimenes M (2013) Centris aenea (Hymenoptera, Apidae): a ground-nesting bee with high pollination efficiency in Malpighia emarginata DC (Malpighiaceae). Sociobiology 60(3): 317-322

Oliveira R, Schlindwein C (2009) Searching for a manageable pollinator for acerola orchards: the solitary oil-collecting bee Centris analis (Hymenoptera: Apidae: Centridini). J Econ Entomol 102(1): 265-273

Pickering CM, Hill W (2007). Impacts of recreation and tourism on plant biodiversity and vegetation in protected areas in Australia. J Environ Manage 85(4): 791-800

Pielou EC (1966) An Introduction to Mathematical Ecology. John Wiley, New York

R Development Core Team (2012) R: A Language and Environment for Statistical Computing. R foundation for Statistical Computing, Vienna.

Ramalho M, Kleinert-Giovannini A, Imperatriz-Fonseca VL (1990) Important bee plants for stingless bees (Melipona and Trigonini) and Africanized honeybees (Apis mellifera) in neotropical habitats: a review. Apidologie 21(5): 469-488

Renner SS, Schaefer H (2010) The evolution and loss of oil-offering flowers: new insights from dated phylogenies for angiosperms and bees. Philos T Roy Soc B 365(1539): 423-435

Roberts RB, Vallespir SR (1978) Specialization of hairs bearing pollen and oil on the legs of bees (Apoidea: Hymenoptera). Ann Entomol Soc Am 71: 619-627

Roig-Alsina A (2000) Claves para las especies argentinas de Centris (Hymenoptera, Apidae), con descripción de nuevas especies y notas sobre distribución. Rev Mus Argent Cienc Nat 2(2): 171-193 
Rosas-Guerrero V, Aguilar R, Martén-Rodríguez S, Ashworth L, Lopezaraiza-Mikel M, Bastida JM, Quesada M (2014) A quantitative review of pollination syndromes: do floral traits predict effective pollinators?. Ecol lett 17(3): 388-400

Roulston TH, Cane JH, Buchmann SL (2000) What governs protein content of pollen: pollinator preferences, pollen-pistil interactions, or phylogeny?. Ecol monogr 70(4): 617-643

Santos RM, Aguiar CM, Dórea MC, Almeida GF, Santos FAR, Augusto SC (2013) The larval provisions of the crop pollinator Centris analis: pollen spectrum and trophic niche breadth in an agroecosystem. Apidologie 44(6): 630-641

Schlindwein C (1998) Frequent oligolecty characterizing a diverse bee-plant community in a xerophytic bushland of subtropical Brazil. Stud Neotrop Fauna E 33:46-59

Schlindwein C (2000) A importância de abelhas especializadas na polinização de plantas nativas e conservação do meio ambiente. In: IV Encontro Sobre Abelhas Encontro Sobre Abelhas, Ribeirão Preto, Anais, pp 131-141 (2004a) Abelhas solitárias e flores: especialistas são polinizadores efetivos? In: Livro de Trabalhos Completos. 55 ${ }^{\circ}$ Congresso Nacional de Botânica, $26^{\circ}$ Encontro Regional de Botânicos de MG, BA, ES, Viçosa, MG, 2004, Sociedade Botânica do Brasil. pp 1-8 (2004b) Are oligolectic bees always the most effective pollinators. In: Solitary bees. Conservation, rearing and management for pollination, Imprensa Universitária, Fortaleza, pp 231-240

Shannon CEA (1948) Mathematical theory of communication. Bell Syst Technol J 27: $379-423$

Sigrist MR, Sazima M (2004) Pollination and reproductive biology of twelve species of Neotropical Malpighiaceae: stigma morphology and its implications for the breeding system. Ann Bot 94: 33-41

Silva JMC, Bates JM (2002) Biogeographic Patterns and Conservation in the South American Cerrado: A Tropical Savanna Hotspot. BioScience 52(3): 225-234

Silva CI, Imperatriz-Fonseca VL, Groppo M, Bauermann SG, Saraiva AA, et al. (2014) Catálogo Polínico das Plantas Usadas por Abelhas no Campus da USP de Ribeirão Preto. Holos, Ribeirão Preto

Silveira FA (1991) Influence of pollen grain volume on the estimation of the relative importance of its source to bees. Apidologie 22(5): 495-502 
Simpson BB (1982) Krameria (Krameriaceae) flowers: orientation and elaiophore morphology. Taxon 31(3): 517-528

Simpson BB, Neff JL, Dieringer G (1990) The production of floral oils by Monttea (Scrophulariaceae) and the function of tarsal pads in Centris bees. Plant Syst Evol 173: 209-222

Slatyer RA, Hirst M, Sexton JP (2013) Niche breadth predicts geographical range size: a general ecological pattern. Ecol lett 16(8): 1104-1114

Taniguchi M (2010) Morfologia das estruturas envolvidas na coleta e transporte de óleo floral por fêmeas do gênero Centris (Hymenoptera, Apidae). Dissertation, Universidade de São Paulo

Tasei JN (1973) Le comportement de nidification chez Osmia (Osmia) cornuta Latr et Osmia (Osmia) rufa L (Hymenoptera, Megachilidae). Apidologie 4(3): 195-225

Thompson JN (2006) Mutualistic webs of species. Science 312(5772): 372-373

Vogel S (1974) Ölblumen und ölsammelnde Bienen. Trop Subtrop Pflanzenwelt 7: 285547 (1990) History of the Malpighiaceae in the light of the pollination ecology. Mem N Y Bot Gard 55: 130-142

Waser NM, Chittka L, Price MV, Williams N, Ollerton J (1996) Generalization in pollination systems, and why it matters. Ecology 77:279-96 
CAPIITOLO 4

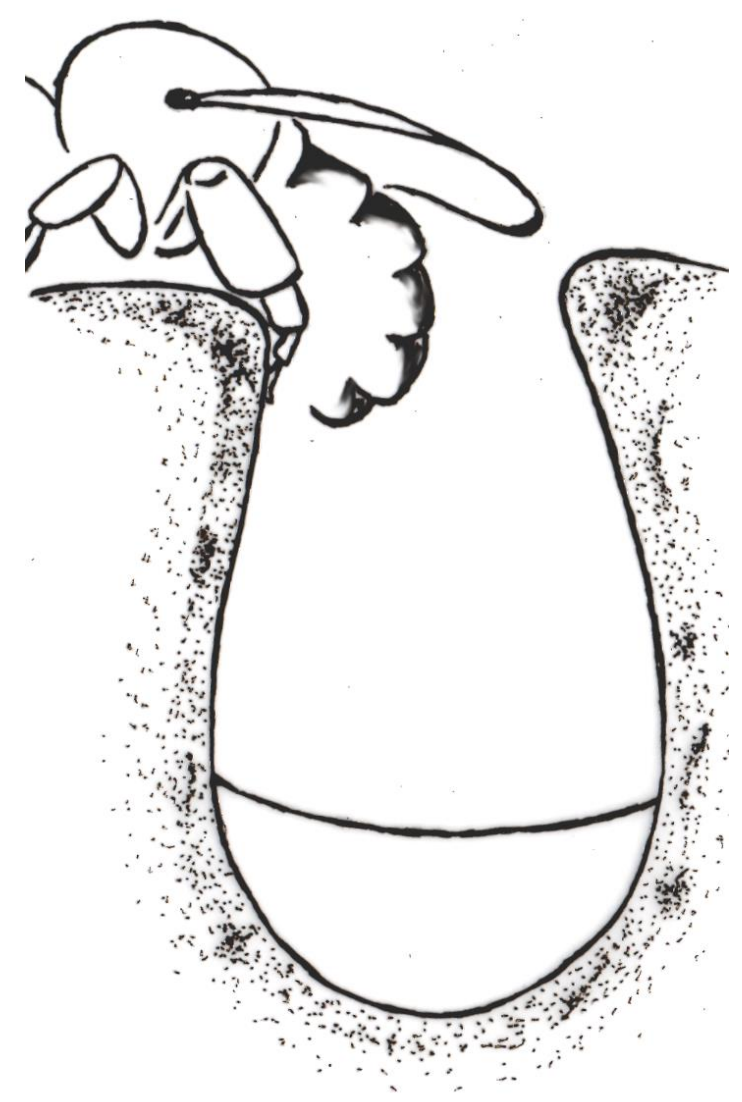




\title{
CHAPTER 4
}

Manuscript formated to be submitted in the Apidologie

\section{Nutritional analysis of diet of two species of Centris (Paracentris) Cameron bees}

William O. SABINO ${ }^{1}$, Isabel ALves-Dos-SAnTos ${ }^{1}$, Cláudia Inês da Silva ${ }^{1}$, José Elton de M. NASCIMENTO², Euzânia Sales PEREIRA², Daniel PAPAJ ${ }^{3}$ and Stephen L. BUCHMANN ${ }^{3,4}$

1. Departamento de Ecologia, Instituto de Biociências, Universidade de São Paulo, SP 05508-900, Brazil. 2. Departamento de Zootecnia, Universidade Federal do Ceará, Fortaleza, CE 60356-000, Brazil. 3. Department of Ecology and Evolutionary Biology, University of Arizona, Tucson, AZ 85721, USA. 4. Department of Entomology, University of Arizona, Tucson, AZ 85721, USA.

Short title: Nutritional analysis of Centris' diet

\begin{abstract}
The study of the nutritional requirements of an individual allows to know more about interactions between organisms and their environment. The nutritional demand of insects not differs from other animals. In the case of bees, females collect resource in flowers to feed the larva and themselves. And solitary bees provide at once food for the whole life of the larva. Here, we analyze the nutritional diet of two species of the same lineage but with different nesting strategy: the oil-collecting bee Centris (Paracentris) burgdorfi, that nest in dunes region in Northeastern Brazil and Centris (Paracentris) pallida, a bee that lost the oil-collecting behavior, from Sonoran Desert in USA. We collect 69 cells of each species to analyze the nutritional value of the larval food. The diet of the two species was completely distinct in the NMDS analyses. Despite similarities in mineral matter, we find a higher proportion of proteins and lipids in C. burgdorfi diet and a higher proportion of carbohydrates in C. pallida diet. They have in common the use of Leguminosae plants as pollen source. C. burgdorfi uses mainly Chamecrista (2 species) as source of pollen. These plants have poricidal anthers, which usually has high level of protein in the pollen grains. C. pallida uses mainly Parkinsonia and Olneya species, which seems to be the nectar and pollen sources. The differences in nesting strategies between the two species reflected in nutritional differences in their diet.
\end{abstract}

Key words: Centridini, oil-collecting bees, pollen analysis, solitary bees, Sonoran Desert 
Resumo $\mathrm{O}$ estudo das necessidades nutricionais de um indivíduo permite saber mais sobre as interações entre os organismos e seu ambiente. A demanda nutricional de insetos não difere de outros animais. No caso das abelhas, as fêmeas coletam recursos em flores para alimentar a larva e eles mesmas. As abelhas solitárias devem fornecer, de uma só vez, alimento para toda a vida da larva. Neste trabalho nós analisamos a dieta nutricional de duas espécies de abelhas da mesma linhagem, mas com diferentes estratégias de nidificação: a abelha coletora de óleo Centris (Paracentris) burgdorfi, que nidifica na região das dunas do Nordeste do Brasil e Centris (Paracentris) pallida, uma abelha que perdeu o comportamento de coleta de óleo, do Deserto de Sonora nos EUA. Coletamos 69 células de cada espécie para analisar o valor nutricional do alimento larval. A análise NMDS mostrou que dieta das duas espécies foi completamente distinta. Apesar de semelhanças na matéria mineral, encontramos uma maior proporção de proteínas e lipídios na dieta de $C$. burgdorfi e uma maior proporção de carboidratos na dieta de $C$. pallida. Eles têm em comum o uso de plantas Leguminosae como fonte de pólen. Centris burgdorfi usa principalmente Chamecrista (2 espécies) como fonte de pólen. Estas plantas têm anteras poricidas, que geralmente tem alto nível de proteína nos grãos de pólen. C. pallida usa principalmente espécies de Parkinsonia e Olneya, que que são tanto fontes de néctar quanto de pólen. As diferenças nas estratégias de nidificação entre as duas espécies refletiram-se nas diferenças nutricionais na sua dieta.

Palavras-chave: Abelhas coletoras de óleo, abelhas solitárias, análise polínica, bromatologia, Deserto de Sonora 


\section{INTRODUCTION}

Nutritional ecology is central to proper interpretations of life history phenomena (e.g. manner of feeding, habitat selection, defense, and reproduction) both in ecological and evolutionary time (Scriber and Slansky 1981). There is extensive literature about insect nutrition (e.g. House 1958, 1961; Daad 1973; Taylor 1981, Slansky 1982; Douglas 2009). Except for the lack of being able to synthesize sterols, it is now quite apparent that insects do not differ markedly from other animals in their fundamental nutritional requirements (Beck and Reese 1976). The qualitative requirements generally differ very little among the insects (House 1958). On the other hand, the quantitative nutritional requirements seem to be complex and possibly are of greater significance in terms of variation among species (House 1961).

Bees, social and solitary, differ from other insects in feeding on nectar and pollen, gathered by adult females (Nicolson 2011). Under natural conditions, pollen supplies the necessary proteins for bees (Haydak 1970; Roulston and Cane 2000), while the nectar is used for the energy-providing sugars that it contains (Baker and Baker 1973). Bees usually prefer to collect concentrated nectars, which maximize their energy gains (Roubik and Buchmann 1984). On the other hand, some bees collect floral oil, and it provides more than twice the energy of nectar on a per-unit volume basis, which may explain the convergence of some groups (about 400 species of 6 tribes) to feed the larvae with this resource (Simpson and Neff 1981; Buchmann 1987).

The nutritive value of pollen from different plants varies considerably (Levin and Haydak 1957; Standifer 1967). The need for protein during brood rearing is dramatically illustrated by the cannibalism of younger honeybee larvae that is induced by experimental pollen shortages in the colony (Schmickl and Crailsheim 2001). Underfed larvae have a higher risk of developmental failure and develop into dwarf adults (Jay 1963). The nutritional content present on brood cells is relatively well known for some species like honey bees (e.g. Haydak 1970; Human and Nicolson 2006; Brodschneider and Crailsheim 2010) but little is known for other bees (e.g Levin and Haydak 1957; Roulston and Cane 2000, 2002), especially for Centris Fabricius bees (e.g. Vinson et al. 2006).

The genus Centris includes about 230 species of solitary bees spread from Argentina to the southern United States (Moure et al. 2007). Species of Centris collect floral oil, and use to feed the larvae and to line the brood cells (Vogel 1974, 1990; 
Simpson et al. 1977; Simpson and Neff 1981; Buchmann 1987; Vinson et al. 1996). Although they are most abundant in humid tropical areas, some species of Centris occur in semi-arid and subtropical regions. The subgenus Centris (Paracentris) Cameron, for example is most commonly represented in semi-desert, Andean regions, xeric areas in North American or semi-arid northeastern Brazil (Snelling 1984; Zanella 2002; Michener 2007).

Oil-producing flowers are found most, but not exclusively, in Neotropical savannas and forests (Buchmann 1987). The production of floral oil is present in 11 plant families (Renner and Schaefer 2010). The floral oil is produced in secretory glands called elaiophores, which may be in the form of trichomes, as seen in Calceolariaceae, Cucurbitaceae, Iridaceae, Myrsinaceae, Plantaginaceae, Scrophulariaceae, Solanaceae and Stilbaceae or epithelium found in flowers of Malpighiaceae and Krameriaceae (Vogel 1974; Simpson and Neff 1981; Buchmann 1987; Alves-dos-Santos et al. 2007).

To collect, manipulate and transport the floral lipids the bees hold specialized structures in their legs (Roberts and Vallespir 1978; Neff and Simpson 1981; RoigAlsina 1997; Alves-dos-Santos et al. 2007). In fact, some species of Centris have lost these structures entirely. This is the case of Centris Paracentris pallida whose fore- and midbasitarsal combs are virtually absent (Neff and Simpson 1981). C. pallida does not collect floral oil and instead lines the nest cell with a glandular secretion (Rozen and Buchmann 1990).

The purpose of this study was to analyze the nutritional value of the diet of two Centris (Paracentris) species with different strategies: C. burgdorfi, an oil-collecting bee that make nest in petrified dunes in Northeastern of Brazil and C. pallida, a bee that occurs in the Sonoran Desert in USA and does not use oil in its nesting behavior. We expect that this contrast reflects in nutritional differences in their diet.

\section{MATERIAL AND METHODS}

\subsection{Study site}

We collected Centris pallida cells in Sonoran Desert, USA (Fig. 1 A-B). The Sonoran Desert extends from the northern end of the Gulf of California into the western half of Sonora, Mexico, southwestern Arizona, southeastern California, and Baja California (Turner and Brown 1982). The cells were collected primarily on Tumamoc 
Hill (T. Hill), which comprises 352 ha of Sonora Desert vegetation on land belonging to the State of Arizona $\left(32^{\circ} 13.267^{\prime} \mathrm{N} ; 111^{\circ} 00.655^{\prime} \mathrm{W}\right.$; elevation: $\left.724 \mathrm{~m}\right)$. This hill is an outlier of the Tucson Mountains, Pima County, Arizona, USA, and is situated west of downtown Tucson (Bowers 2005). In this area, there are two species of floral oilproducing plants: Krameria bicolor S. Wats. (cited many times as K. grayi) (Simpson 1989) and Janusia gracilis A. Gray belonging to the family Malpighiaceae, which is among the most common plants on site (Bowers 2005).

We also searched for $C$. pallida nests on a region close to the Ironwood Ridge High School (32 $24.477^{\prime} N$; $111^{\circ} 01.655^{\prime} \mathrm{W}$; elevation: $808 \mathrm{~m}$; IHS) in Tucson, AZ. This location is about $20 \mathrm{~km}$ from T. Hill and, despite having similar vegetation, is marked by the absence of Krameria and the presence of Olneya tesota (Ironwood), a tree described in the literature as a source of pollen and nectar of $C$. pallida (see Alcock et al. 1976; Rozen and Buchmann 1990). This species is not present at T. Hill and has a late flowering period compared to that of other floral resources used by $C$. pallida.

Centris burgdofi cells were collected in Rio Grande do Norte state, Northeastern, Brazil (Fig 1 C-D). The females nest in petrified dunes in a place called "Deserto dos Anjos", which belong to the coastal dunes. It stays about $25 \mathrm{~km}$ from the city of Natal, RN ( $05^{\circ} 36.310^{\prime} \mathrm{S}, 35^{\circ} 14.435^{\prime} \mathrm{W}$; elevation: $\left.41 \mathrm{~m}\right)$. The coastal dunes are mobile, with no vegetation cover or with sand-weeding herbaceous vegetation (Freire 1996). Eventually, these dunes may be covered by arboreal-shrub vegetation, forming sparse clumps where males and females of $C$. burgdorfi are seen collection resources (Sabino et al. 2017). Is remarkable the presence of floral oil-producing plants like Byrsonima spp. and Krameria tomentosa. The average temperature is around $26.7^{\circ} \mathrm{C}$ and the rainy season is from March to August, with an average annual rainfall of $1643.48 \mathrm{~mm}$ (INMET / UFRN 2002).

\subsection{Data collect}

We visited T. Hill and IHS several times to find $C$. pallida nests. The visits were made in 2016 from March to May, which corresponds to the period when the species is more active. Centris pallida usually nests in large aggregations and each female constructs only one cell per nest, rarely two (Alcock et al. 1976; Rozen and Buchmann 1990). When a nest was found, we marked the entrance with a flag and waited until the female finish it. After the end of the nest the female covered the access tunnel with earth 
and left the site. We dug the fresh cells and save the content for nutritional analysis. We obtained a total of 53 cells in T. Hill and 16 in IHS.

We collected the $C$. burgdorfi cells in April 2016 on the species activity peak in Natal. In contrast to C. pallida, C. burgdorfi females make several cells per nest (Sabino et al. unpublish data). We collected 69 cells from different nests and the pollen material was sampled in brood cells was kept in $2 \mathrm{~mL}$ cryovial tubes and frozen until the nutritional analysis.
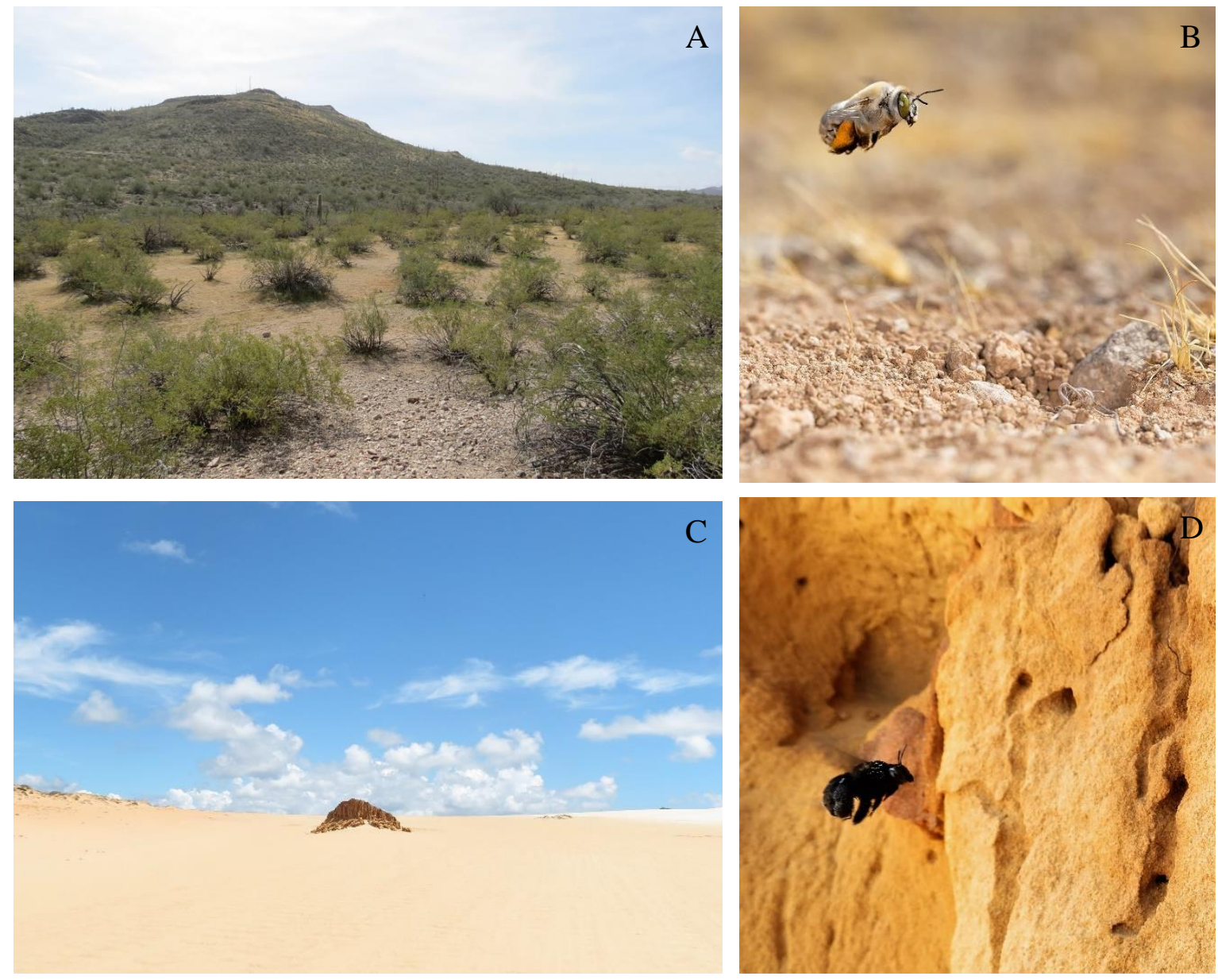

Figure 1. Study sites where the cells were collected. A) Sonoran Desert at Tumamoc Hill in Tucson, Arizona, USA. B) Centris (Paracentris) pallida female arriving in the nest with the scopae full of pollen in T. Hill. C) The dunes area near to Natal, Rio Grande do Norte, Brazil. D) Centris (Paracentris) burgdorfi female arriving in the nest with the scopae full of oil. Photo B was kindly provided by Bruce D. Taubert. 


\subsection{Pollen analyses}

We homogenized the samples and separate a little amount of the material from each cell to the pollen analyses. We centrifuged the pollen material at $2000 \mathrm{rpm}$ for 10 min and the ethanol was discarded. In the next step, we added $4 \mathrm{~mL}$ of glacial acetic acid to the pollen pelleted in the tubes and these were left to stand for $24 \mathrm{~h}$. Subsequently, we acetolysed the pollen grains present in the samples by acetolysis technique (Erdtman 1960). We embedded the samples in Kisser gelatin and sealed the slides with transparent varnish. For each sample two slides were made to identify this material. The identification of pollen grains was performed at the most specific taxonomic level possible, using a light microscope. The frequencies of occurrence of each taxon was obtained from each slide. To enable a more accurate identification of the pollen, we made references slides of the flowering species in each sampling area. We took the anthers and subjected them to acetolysis following the protocol proposed by Silva et al. (2014).

We described Parkinsonia pollen grains to try separate taxonomically the two species ( $P$. florida and P. microphylla) that occur in T. Hill during the period of $C$. pallida activity. For this, using 30 grains from each species, we analyze: measurements of the equatorial and polar axis, number and shape of the pores, thickness and ornamentation of the exine (Supplementary material).

We made observations in the flowers to identify if the females were collecting nectar, pollen or oil. With these observations was possible to link the pollen analysis with the resource collected in the plant.

\subsection{Nutritional analyses}

The samples were analyzed according to AOAC (1990). The pollen sample was first defatted by ethyl ether extraction (Fat - method number 920.39), Dry matter (DM, with fat - method number 930.15), mineral matter (MM - method number 924.05). To analyze crude protein (CP - method number 984.13) we subjected $0.1 \mathrm{~g}$ samples of pollen to the Kjeldahl method, as mentioned for the ingredients of the experimental concentrate, in fat-free samples. The total carbohydrate content (TC) was calculated according to Sniffen et al. (1992): TC $(\%)=100-(\% \mathrm{CP}+\% \mathrm{EE}+\%$ ash $)$. 
Because the amount of food in each brood cell is considered small (about two grams per cell for both $C$. pallida and $C$. burgdorfi) some samples had to be amalgamated so that nutritional analyzes could be done. Thus, it was possible to obtain 14 nutritional samples that were evaluated for the proportion of each nutrient (mineral matter, protein, carbohydrate and lipids). This is this is allowed since we are interested in nutritional differences between species and not between individuals.

The results are shown as mean \pm standard error.

\subsection{Data analysis}

To evaluate which plants the bees use to collect the floral resources, we made qualitative analysis to identify the plant species found in the samples. After qualitative analysis, a quantitative analysis assessed the importance of each plant in the larval and adult diet. For that, we examined the first 400 pollen grains in each sample, as suggested by Montero and Tormo (1990).

From the proportion data, we evaluated the trophic niche using the index of Shanonn-Wiener (1948) $\left(H^{\prime}\right)$. To check the uniformity in the samples, we used the index of Pielou (1966) $\left(J^{\prime}\right)$, and to analyze the dominance we applied the index of BergerParker (Magurran 2004) (D). Analyses of diet breadth were performed using the statistical software PAST 2.17c (Hammer et al. 2001). We also analyzed the index of interindividual niche variation $(E)$ in the network that was achieved using the software Dieta 1.0 (Araujo et al. 2008). We made the representation of the trophic interaction network as bipartite graphs (Dormann et al. 2008) using the bipartite package for $\mathrm{R}$ v.3.3.2 (R Development Core Team, 2016).

We used multivariate analysis to describe general feeding patterns between $C$. burgdorfi and C. pallida. We chose nonmetric multidimensional scaling (NMDS), a form of ordination, to describe the proportions of the nutrients (mineral matter, protein, lipids and carbohydrate) in the diet of the two Centris species. This procedure condenses a data set to one point in a two-dimensional plane so that highly similar sets are plotted close together (Faith et al. 1987). The contribution of each nutrient to the pattern presented by NMDS was made through the similarity percentage (SIMPER) analysis. We tested the statistical significance of differences between food compositions at sampled grids using one-way ANOSIM. This is a non-parametric procedure for 
testing the significance of possible differences between a priori classified groups. We used the statistical software PAST 2.17c.

\section{RESULTS}

\subsection{The diet composition of the two species}

For $C$. pallida, we identified five species of Leguminosae (Tab. 1). Two species of the genus Parkinsonia are the main source of pollen and nectar, with a high frequency of occurrence in the slides. Parkinsonia microphylla was the most abundant species in the cells of both places: T. Hill (80.33\% of the pollen grains) and IHS (70.02\% of the pollen grais). Olneya tesota shows as an alternative pollen and nectar resource in IHS, with $29.96 \%$ of all pollen grains presents in nests collected in that area (Fig. 2).

Table 1. Proportion of each plant species identified in the diet of Centris (Paracentris) pallida in Sonoran Desert, Arizona, USA. T. Hill= Tumamoc Hill; IHS= Ironwood High School. Abbrev. $=$ Abbreviation. $\mathrm{RPP}=$ Resource present in the plant: $\mathrm{P}=$ pollen and $\mathrm{N}=$ nectar.

\begin{tabular}{lcrcc}
\hline \multicolumn{1}{c}{ Species/Pollen type } & RPP & \multicolumn{2}{c}{ Proportion } \\
\cline { 3 - 5 } & & T. Hill & IHS \\
\hline Leg.-Caesalpinioideae & & & \\
Parkinsonia florida (Benth. ex A. Gray) S. Watson. & PN & 19.64 & - \\
Parkinsonia microphylla Torr. & PN & 80.33 & 70.02 \\
Prosopis velutina Woot. & PN & 0.01 & - \\
Senna covesii & P & - & 0.02 \\
Leg.-Papilionoideae & & & \\
$\quad$ Olneya tesota A. Gray & PN & - & 29.96 \\
Indeterminate & - & & 0.01 & - \\
\hline$H^{\prime}$ & 0.65 & & \\
$J^{\prime}$ & 0.36 & & \\
$D$ & 0.64 & & \\
$E$ & 0.36 & & \\
\hline$H^{\prime}=$ index of Shanonn-Wiener, $J^{\prime}=$ index of Pielou, $D=$ index of Berger-Parker, $E=$ interindividual niche variation.
\end{tabular}




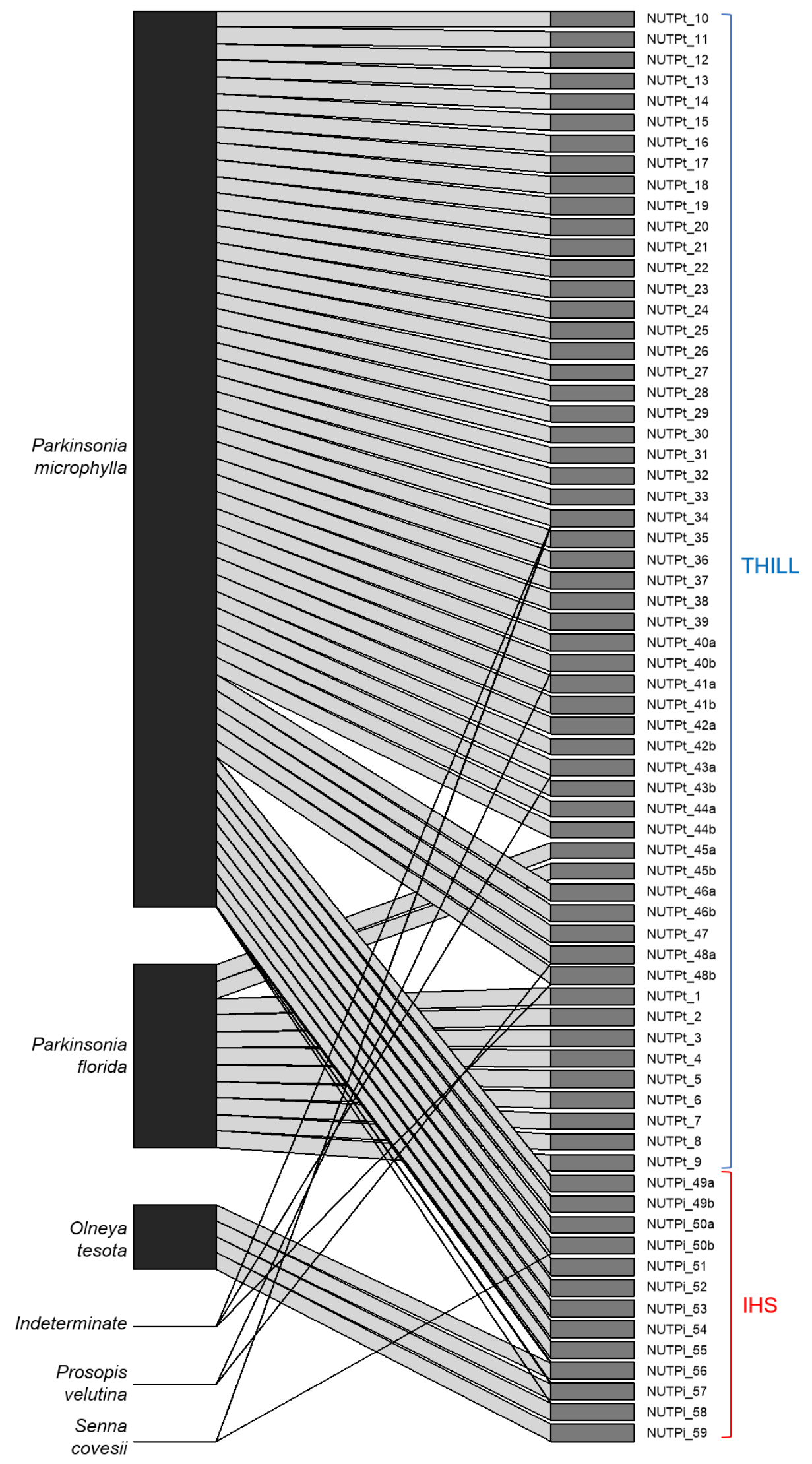

Figure 2. Diet in individual Centris pallida cells collected in Tumamoc Hill (blue group) and Ironwood High School (red group), both in Sonoran Desert in Tucson, Arizona, USA. 
Centris burgdorfi diet is more diversified with 13 plant species belonging to nine families (Tab. 2; Fig. 3). Plants of the genus Chamaecrista (Leg.-Caesalpinioideae) seems to be the main source of pollen, with a high frequency of occurrence in the samples (Chamaecrista hispidula (Vahl.) Irwin \& Barneby $=41.84 \%$ and Chamaecrista flexuosa (L.) Greene $=36.06 \%$ of all pollen grains counted). Cuphea flava Spreng. (Lythraceae) was a major source of nectar, being represented by $19.41 \%$ of all pollen grains. The source of floral oil comes exclusively from Krameria tomentosa A. St.-Hil. (Krameriaceae), arising in all the sampled slides (2.11\% of all pollen grains).

When we estimated the diversity, evenness, and dominance indexes of the diet composition of $C$. burgdorfi and $C$. pallida, we found a variation among the two species (Tabs. 1 and 2). The samples with the highest richness had also higher diversity $\left(H^{\prime}{ }_{\text {C.burgdorf }}=1.17 ; H^{\prime}\right.$ C.pallida $\left.=0.65\right)$. We observed a higher dominance index in $C$. pallida diet $\left(D_{\text {C.burgdorfi }}=0.34 ; D_{\text {C.pallida }}=0.64\right)$ but a higher evenness was observed in $C$. burgdorfi samples ( $\left.J_{\text {C.burgdorfi }}^{\prime}=0.46 ; J_{\text {C.pallida }}^{\prime}=0.36\right)$. The interindividual niche variation was very similar for both species $\left(E_{C . b u r g d o r f i}=0.38 ; E_{C . p a l l i d a}=0.36\right)$.

\subsection{Nutritional analysis}

The NMDS shows that the diet of the two species differ nutritionally (Fig. 4) and the distributition was significant $(\mathrm{R}=0.86, p<0.05)$. According to the SIMPER analysis, the proportion of carbohydrates was responsible for $46.82 \%$ of the diffence following by lipids $(20.26 \%)$, protein $(18.96 \%)$ and mineral matter $(13.96 \%)$. The mineral matter is similar for both species (Fig. 5A) but the C. burgdorfi diet has a higher proportion of proteins $(26.88 \pm 0.88)$ than $C$. pallida $\operatorname{diet}(18.49 \pm 1.32$; Fig. $5 \mathrm{~B})$. The carbohydrates, on the other hand, are higher in $C$. pallida provision $(69.07 \pm 2.12)$ compared to $C$. burgdorfi (46.25 \pm 1.37 ; Fig. 5C). The proportion of lipids in the diet C. burgdorfi is 9.2 times higher $(11.06 \pm 0.5)$ than in the diet of $C$. pallida $(1.2 \pm 0.16$; Fig. 5D). 
Table 2. Proportion of each plant species identified in the diet of Centris (Paracentris) burgdorfi in a dunes area in Rio Grande do Norte, Brazil. Abbrev. = Abbreviation. $\mathrm{RPP}=$ Resource present in the plant: $\mathrm{O}=$ oil, $\mathrm{P}=$ pollen and $\mathrm{N}=$ nectar.

\begin{tabular}{|c|c|c|}
\hline Species/Pollen type & RPP & Proportion \\
\hline \multicolumn{3}{|l|}{ Anacardiaceae } \\
\hline Anacardium sp. & PN & 0.01 \\
\hline \multicolumn{3}{|l|}{ Asteraceae } \\
\hline Vernonia sp. & $\mathrm{PN}$ & 0.14 \\
\hline \multicolumn{3}{|l|}{ Convolvulaceae } \\
\hline Merremia sp. & $\mathrm{PN}$ & 0.21 \\
\hline \multicolumn{3}{|l|}{ Krameriaceae } \\
\hline Krameria tomentosa A. St.-Hil. & $\mathrm{PO}$ & 2.11 \\
\hline \multicolumn{3}{|l|}{ Lamiaceae } \\
\hline sp. 1 & - & 0.02 \\
\hline \multicolumn{3}{|l|}{ Leg. -Caesalpinioidea } \\
\hline Chamaecrista hispidula (Vahl.) Irwin \& Barneby & $\mathrm{P}$ & 41.84 \\
\hline Chamaecrista flexuosa (L.) Greene & $\mathrm{P}$ & 36.06 \\
\hline Mimosa sp. & PN & 0.04 \\
\hline \multicolumn{3}{|l|}{ Leg.-Papilionoideae } \\
\hline Cajanus sp. & PN & 0.03 \\
\hline Centrosema brasilianum (L.) Benth & PN & 0.07 \\
\hline \multicolumn{3}{|l|}{ Lythraceae } \\
\hline Cuphea flava Spreng. & $\mathrm{PN}$ & 19.41 \\
\hline \multicolumn{3}{|l|}{ Malvaceae } \\
\hline Sida sp. & PN & 0.01 \\
\hline \multicolumn{3}{|l|}{ Rubiaceae } \\
\hline Richardia sp. & $\mathrm{PN}$ & 0.04 \\
\hline$H^{\prime}$ & & 1.17 \\
\hline$J^{\prime}$ & & 0.46 \\
\hline$D$ & & 0.34 \\
\hline$E$ & & 0.38 \\
\hline
\end{tabular}




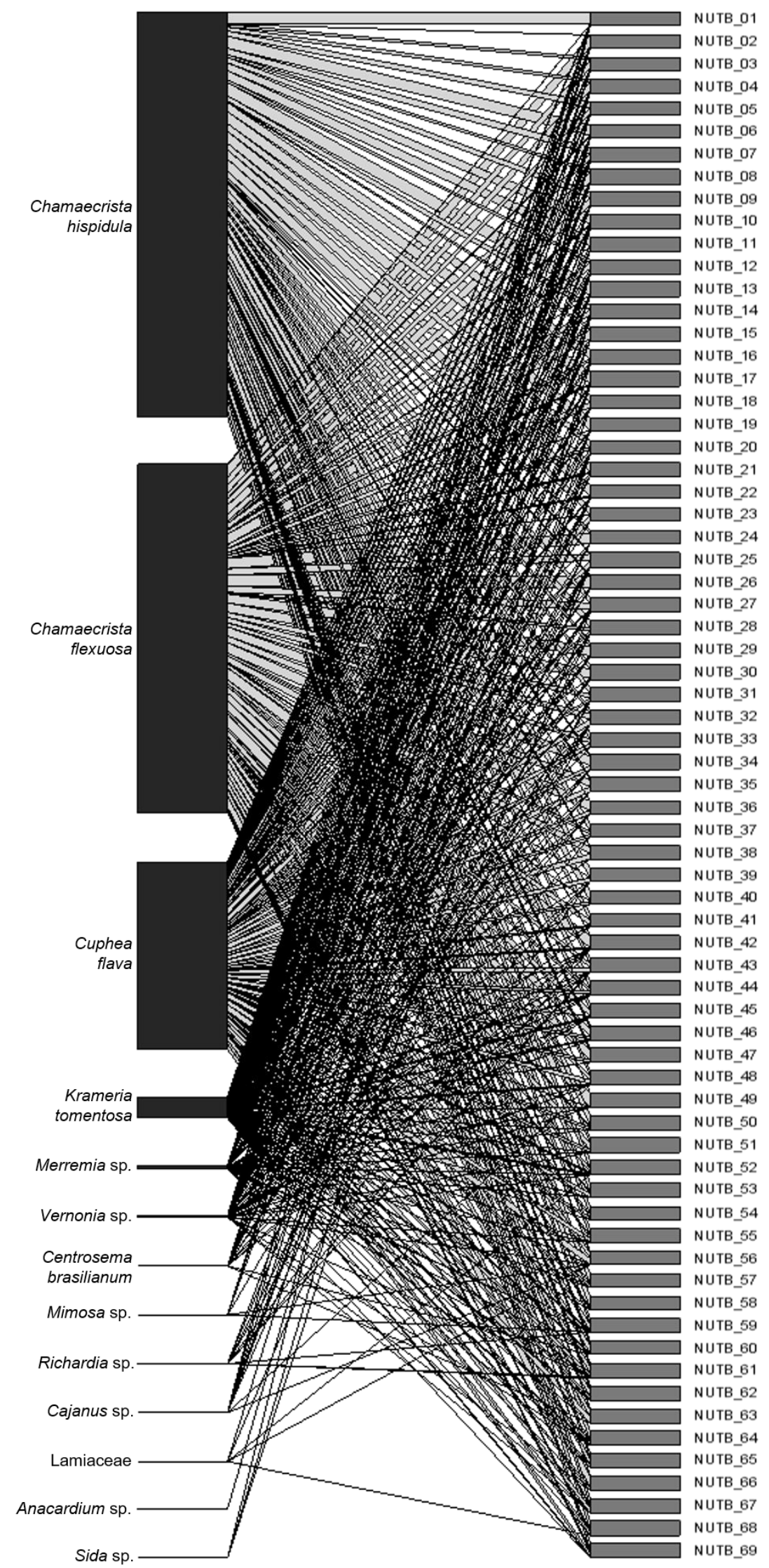

Figure 3. Diet in individual Centris burgdorfi cells collected in dunes area close in Rio Grande do Norte, Brazil. 


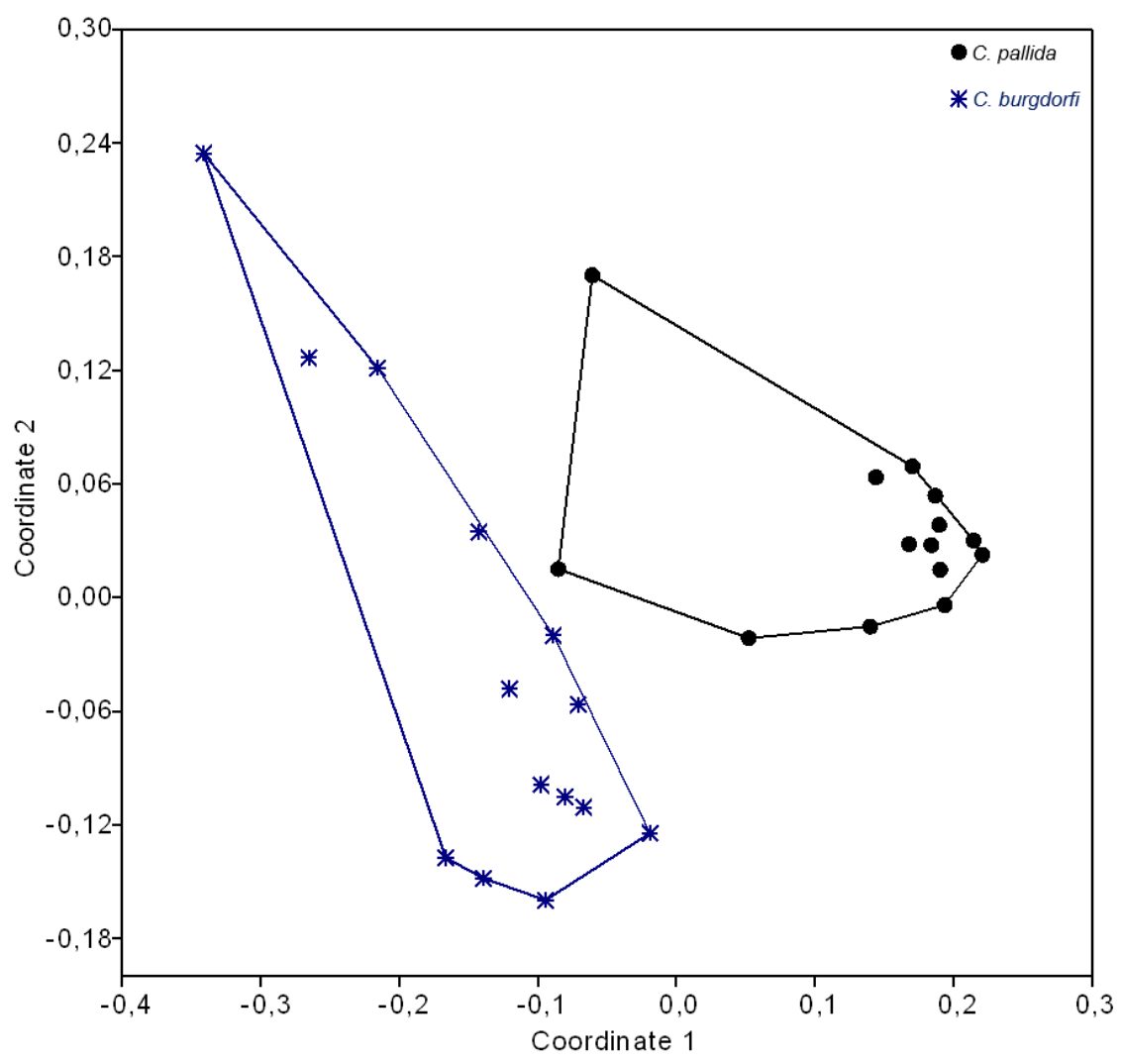

Figure 4. Non-metric Multidimensional Scaling (NMDS) showing variation between the diet (proportion of mineral mater, protein, carbohydrates and lipids) of Centris (Paracentris) pallida cells collected in Sonoran Desert in Arizona, USA, and Centris (Paracentris) burgdorfi cells collected in dunes area in Rio Grande do Norte, Brazil.

\section{DISCUSSION}

Although both species belong to the same subgenus, C. burgdorfi and C. pallida differ in many aspects in their diet composition. The diet of $C$. burgdorfi is rich in proteins and lipids, while $C$. pallida diet has a considerable amount of carbohydrates.

Females of $C$. burgdorfi use primary Chamaecrista flowers as source of pollen to feed the larvae. Chamaecrista has poricidal anthers and Centris bees are able to collect pollen through vibration (Buchmann 1985). Rolston et al. (2000) comparing pollen protein concentrations of plant species possessing vibratile vs. nonvibratile pollination system found that plants with vibratile system tend to have pollen richer in protein than the nonvibratile plants. The plants used by $C$. pallida female as source of pollen (Parkinsonia and Olneya) do not have poricidal anthers. 

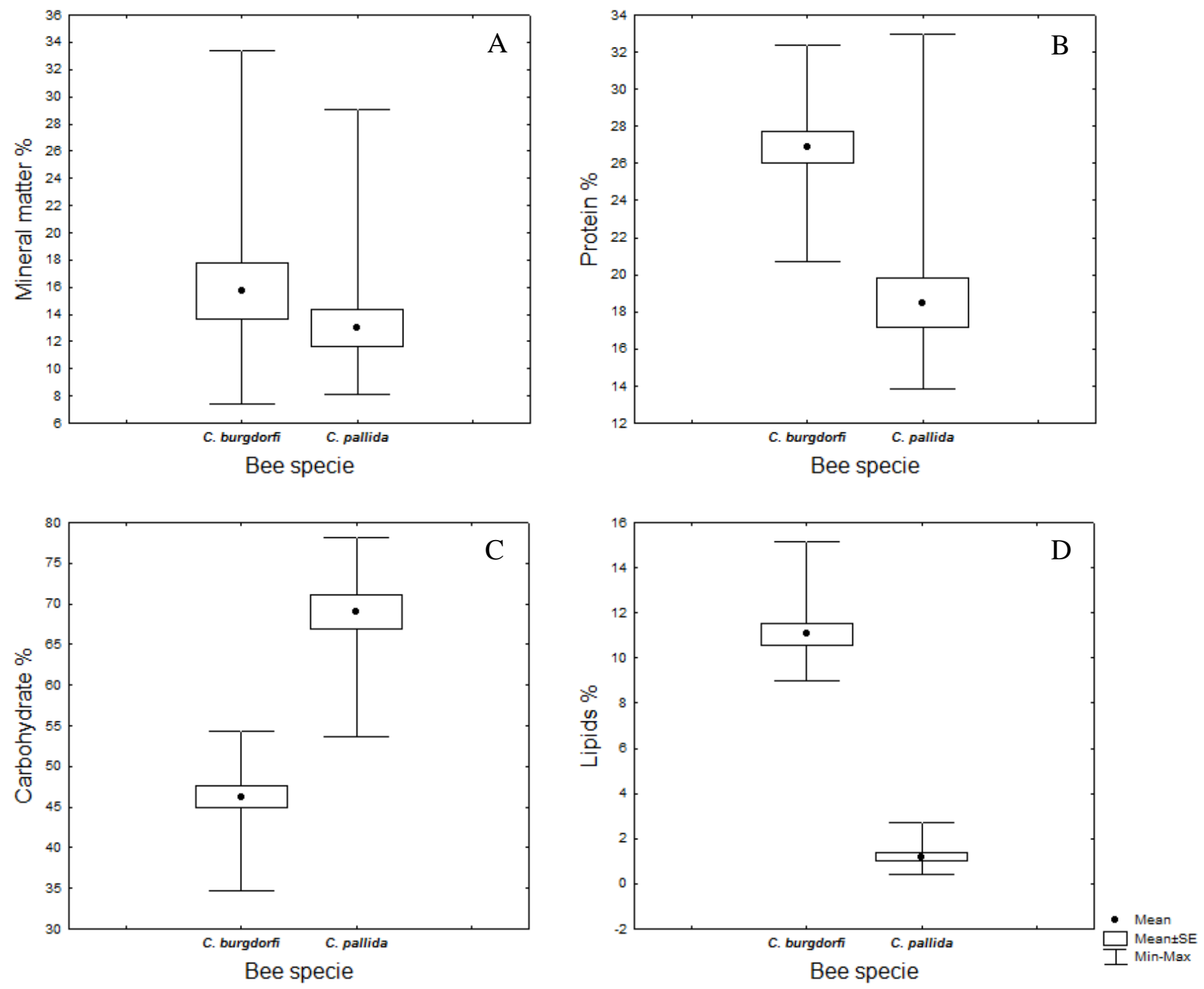

Figure 5. Nutritional analysis of the Centris burgdorfi and Centris pallida diet. A) Mineral Matter; B) Protein; C) Carbohydrates and D) Lipids.

Fresh Parkinsonia microphylla pollen has $46.2 \%$ of protein while fresh Olneya tesota pollen has $44.4 \%$ (Rolston et al. 2000). These two species represent the basic diet of adult and immatures of C. pallida. Nevertheless, its diet is composed by $18.49 \%$ of protein. The difference between fresh and manipulated pollen is remarkable. The quantity of pollen protein decreases after being collected by bees (Nicolson 2011). Sunflower pollen, for example, is considered to be of poor quality for bees because of its low protein content of 13-15\% after collection by bees (Pernal and Currie 2000). 
In contrast to protein, the proportion of carbohydrates in C. pallida provision was higher than in C. burgdorfi. Centris pallida does not use floral oil to feed the larva and, therefore, requires only nectar as source of energy. The energy content in the nectar depends on its volume and sugar concentration (Corbet 2003). A high proportion of pollen-derived carbohydrate may be indigestible to the larvae (Nicolson 2011). The addition of nectar sugars is nutritionally important to bees for making the food more palatable (Nicolson 2011). For desert bees, the nectar is also an important source of water to compensate the large water losses during a foraging trip. These habitats are usually characterized by very low availability of water, and high daytime temperature (Willmer and Stone 1997).

Besides using nectar for own consumption, the significant presence of carbohydrates in $C$. burgdorfi provisions shows that the females are using nectar in addition to floral oil to feed the larvae. One of the questions regarding the ecology of oil-collection bees is if the females add nectar in the larvae provision. And this was reported for some Centris species like: C. maculifrons Smith (Neff and Simpson 1981), C. vittata Lepeletier (Pereira et al. 1999), C. analis Fabricius (Jesus and Garófalo 2000), C. tarsata Smith (Aguiar and Garófalo 2004). For other species the females use only floral oil: C. trigonoides Lepeletier (Simpson et al. 1977), C. adanae Cockerell, $C$. flavifrons Fabricius, C. flavofasciata Friese, and C. aethyctera Snelling (Vinson et al. 1997). Perhaps addition of nectar turns the food more "palatable" to the larva, since the nectar is more watery than the oil (Nicolson 2011).

Proteins and carbohydrates enable the growth of the larvae and cocoon construction activity, but the high amount of lipids in the provision of $C$. burgdorfi possibly has great importance throughout the larval development. During the development of holometabolous insects there are two non-feeding stages, the embryo and the pupa, and the pattern of lipid synthesis and utilization during the course of development reflects preparation for the diapause (Downer and Matthews 1976). Analysed at different periods during the development of Phormia regina (Diptera) larvae, the lipid represented $21.8 \%$ of the fat-body dry weight in the early third instar, whereas in the mature larva it constituted 52.5\% (Wimer and Lumb 1967). In many animals like mammals which do not synthetize lipids, the essential fatty acids must be incorporated through the diet, may form part of the preparation for hibernation (Florant 1998). The value of lipids for this purpose has been documented for squirrels (Frank 1992), marmots (Florant et al. 1993), echidnas (Falkenstein et al. 2001) and black-tailed 
prairie dogs (Lehmer and Horne 2001), for exemple. The lipids collected from Krameria tomentosa should be important for the larva dormancy of $C$. burgdorfi. Floral lipids constitute a more concentrated energy source than nectar, but we have no data to indicate that profits are higher for oil collectors than for bees foraging for nectar if oils are used as an energy source (Neff and Simpson 1981). For honey bees Toth \& Robinson (2005) found that foragers (typically older bees) had lower lipid amounts than did nurses (typically young bees). Lipid levels were low even on the first day of foraging, suggesting that the decline in stored lipid precedes the onset of foraging (Toth and Robinson 2005).

The NMDS shows a higher variation between $C$. burgdorfi samples compared to C. pallida, with some points very distant from each other. This could be associated to the higher diversity and the lower dominancy as showed by the indexes of ShanonnWiener and Berger-Parker. Through the analysis of the individual diet, we observed that C. pallida is more specialized than $C$. burgdorfi, providing the brood cells with pollen and nectar collected from only one species of plant at a time. C. burgdorfi females must collect pollen, nectar and oil from different plants species, wich result in a diet with more variations in the proportion of the nutrients.

We found that the different nesting strategies of C. burgdorfi and C. pallida reflect, not only in the presence of lipids in the diet, but also in carbohydrates and proteins. However, we do not know how much of this is variation implies in the biology of each species. The oil-collecting bees are an interesting system to studies behavioral tactics that can be linked with nutrition, physiology, and many other areas of knowledge.

Acknowledgments The authors are grateful to Paulo Roberto de Castro for the help and all support in the field work and to Astrid Kleinert, Felipe Vivallo for comments and suggestions in the manuscript. The research was supported by Fundação de Amparo à Pesquisa do Estado de São Paulo (FAPESP) and Coordenação de Aperfeiçoamento de Pessoal de Nível Superior (CAPES). 


\section{REFERENCES}

Aguiar, C. M., Garófalo, C. A. (2004) Nesting biology of Centris (Hemisiella) tarsata Smith (Hymenoptera, Apidae, Centridini). Rev. Bras. Zool. 21(3), 477-486

Alcock, J., Jones, C. E., Buchmann, S. L. (1976) The nesting behavior of three species of Centris bees (Hymenoptera: Anthophoridae). J. Kans. Entomol. Soc. 49(4): $469-474$

Alves-dos-Santos, I., Machado, I. C., Gaglianone, M. C. (2007) História natural das abelhas coletoras de óleo. Oecol. Bras. 11(4): 544-557

AOAC. (1990) Official methods of analysis of the Association of Official Agricultural Chemists, 15. ed. Arlington. 500p.

Araujo, M. S., Guimaraes, P. R., Svanback, R., Pinheiro, A., Guimaraes, P., Reis S. F., Bolnick D. I. (2008) Network analysis reveals contrasting effects of intraspecific competitions on individual vs. population diets. Ecology. 89:1981-1993

Baker, H. G., Baker, I. (1973) Amino-acids in nectar and their evolutionary significance. Nature. 241: 243-245

Beck, S. D., Reese, J. C. (1976) Insect-plant interactions: nutrition and metabolism. In: Biochemical Interaction Between Plants and Insects (pp. 41-92). Springer US

Bowers, J. E. (2005) Effects of drought on shrub survival and longevity in the northern Sonoran Desert 1. J. Torrey Bot. Soc. 132(3): 421-431

Brodschneider, R., Crailsheim, K. (2010) Nutrition and health in honey bees. Apidologie. 41(3): 278-294

Buchmann, S. L. (1985) Bees use vibration to aid pollen collection from non-poricidal flowers. J. Kans. Entomol. Soc. 58(3): 517-525

. (1987) The ecology of oil flowers and their bees. Annu. Rev. Ecol. Evol. 18: 343-369

Corbet, S. (2003). Nectar sugar content: estimating standing crop and secretion rate in the field. Apidologie. 34(1): 1-10

Dadd, R. H. (1973) Insect nutrition: current developments and metabolic implications. Annu. Rev. Entomol. 18(1): 381-420

Douglas, A. E. (2009) The microbial dimension in insect nutritional ecology. Funct. Ecol. 23(1): 38-47

Dormann, C.F., Gruber, B., Fründ, J. (2008) Introducing the bipartite package: analyzing ecological networks. R News, 8: 8-11 
Downer, R. G. H., Matthews, J. R. (1976) Patterns of lipid distribution and utilization in insects. Amer. Zool. 16(4): 733-745

Erdtman, G. (1960) The acetolized method. A revised description. Svensk. Bot. Tidskrift. 54: 561-564

Faith, D. P., Minchin, P. R., Belbin, L. (1987) Compositional dissimilarity as a robust measure of ecological distance. Vegetatio. 69(1-3): 57-68

Falkenstein, F., Körtner, G., Watson, K., Geiser, F. (2001) Dietary fats and body lipid composition in relation to hibernation in free-ranging echidnas. J. Comp. Physiol. B. 171(3): 189-194

Florant, G. L., Hester, L., Ameenuddin, S., Rintoul, D. A. (1993) The effect of a low essential fatty acid diet on hibernation in marmots. Am. J. Physiol. Regul. Integr. Comp. Physiol. 264(4): R747-R753

Florant, G. L. (1998) Lipid metabolism in hibernators: the importance of essential fatty acids. Amer. Zool. 38(2): 331-340

Frank, C. L. (1992) The influence of dietary fatty acids on hibernation by goldenmantled ground squirrels (Spermophilus lateralis). Physiol. Zool. 906-920

Freire, E. M. X. (1996) Ecologic and zoogeographic study on a fauna of lizards (Sauria) from Dunas of Natal, Rio Grande do Norte and from Restinga de Ponta de Campina, Cabedelo, Paraíba, Brazil. Rev. Bras. Zool. 13(4): 903-921

Hammer, Ø., Harper, D.A.T., Ryan, P.D. (2001) PAST: Paleontological statistics software package for education and data analysis. Palaeontologia Electronica 4 (1): 9. Available at http://palaeo-electronica.org/2001_1/past/issue1_01.htm.

Haydak, M. H. (1970) Honey bee nutrition. Annu. Rev. Entomol. 15(1): 143-156

House, H. L. (1958) Nutritional requirements of insects associated with animal parasitism. Exp. Parasitol. 7(6): 555-609 . (1961) Insect nutrition. Annu. Rev. Entomol. 6(1): 13-26

Human, H., Nicolson, S. W. (2006) Nutritional content of fresh, bee-collected and stored pollen of Aloe greatheadii var. davyana (Asphodelaceae). Phytochemistry. 67(14): 1486-1492 
INMET/UFRN. (2002) Instituto Nacional de Meteorologia/UFRN. Boletins Climatológicos: anos 1984 a Maio/2002. Estação Climatológica Principal. Natal

Jay, S. C. (1963) The development of honeybees in their cells. J. Apic. Res. 2(2): 117134

Jesus, B. M. V., Garofalo, C. (2000) Nesting behaviour of Centris (Heterocentris) analis (Fabricius) in southeastern Brazil (Hymenoptera, Apidae, Centridini). Apidologie. 31(4), 503-515

Lehmer, E. M., Horne, B. V. (2001) Seasonal changes in lipids, diet, and body composition of free-ranging black-tailed prairie dogs (Cynomys ludovicianus). Can. J. Zool. 79(6): 955-965

Levin, M. D., Haydak, M. H. (1957) Comparative value of different pollens in the nutrition of Osmia lignaria. Bee World. 38: 221-26

Magurran, A. E. (2004) Measuring Biological Diversity. Blackwell Science, Oxford.

Michener, C. D. (2007) The Bees of the World. The Johns Hopkins Univ. Press, Baltimore. Maryland. 2nd ed. 953p.

Montero, I., Tormo, R. (1990) Análisis polínnico de mieles de cuatro zonas montanhosas de Extremadura. Nacl. Asoc. Palinol. Leng. Esp., 5: 71-78

Moure, J. S. Melo, G. A. R. Vivallo, F. (2007) Centridini Cockerell \& Cockerell, 1901, in: Moure, J. S., Urban, D., \& Melo, G. A. R. Catalogue of Bees (Hymenoptera, Apoidea) in the Neotropical Region. Curitiba: Sociedade Brasileira de Entomologia. pp. 83-142.

Neff, J. L., Simpson, B. B. (1981) Oil-collecting structures in the Anthophoridae (Hymenoptera): morphology, function, and use in systematics. J. Kans. Entomol. Soc. $95-123$

Nicolson, S. W. (2011) Bee food: the chemistry and nutritional value of nectar, pollen and mixtures of the two. Afr. Zool. 46(2): 197-204

Pereira, M., Garófalo, C. A., Camillo, E., Serrano, J. C. (1999) Nesting biology of Centris (Hemisiella) vittata Lepeletier in southeastern Brazil (Hymenoptera, Apidae, Centridini). Apidologie. 30: 327-338

Pernal, S., Currie, R. (2000) Pollen quality of fresh and 1-year-old single pollen diets for worker honey bees (Apis mellifera L.). Apidologie. 31(3): 387-409

Pielou, E. C. (1966) An Introduction to Mathematical Ecology. John Wiley, New York.

R Development Core Team (2016) R: A Language and Environment for Statistical Computing. $\mathrm{R}$ foundation for Statistical Computing, Vienna. 
Renner, S. S., Schaefer, H. (2010) The evolution and loss of oil-offering flowers: new insights from dated phylogenies for angiosperms and bees. Phil. Trans. R. Soc. B, 365(1539): 423-435

Roberts, R. B., Vallespir, S. R. (1978) Specialization of hairs bearing pollen and oil on the legs of bees (Apoidea: Hymenoptera). Ann. Entomol. Soc. Am. 71: 619-627

Roig-Alsina, A. (1997). A generic study of the bees of the tribe Tapinotaspidini, with notes on the evolution of their oil-collecting structures. Mitt. Munch. Entomol. Ges. 87: 3-21

Roubik, D. W., Buchmann, S. L. (1984) Nectar selection by Melipona and Apis mellifera (Hymenoptera: Apidae) and the ecology of nectar intake by bee colonies in a tropical forest. Oecologia. 61: 1-10

Roulston, T. H., Cane, J. H. (2000) Pollen nutritional content and digestibility for animals. Plant. Syst. Evol. 222(1-4): 187-209 . (2002) The effect of pollen protein concentration on body size in the sweat bee Lasioglossum zephyrum (Hymenoptera: Apiformes). Evol. Ecol. 16(1): 49-65

Roulston, T. H., Cane, J. H., Buchmann, S. L. (2000) What governs protein content of pollen: pollinator preferences, pollen-pistil interactions, or phylogeny? Ecol Monogr. 70(4): 617-643

Rozen, J. G., Buchmann, S. L. (1990) Nesting biology and immature stages of the bees Centris caesalpiniae, C. pallida, and the cleptoparasite Ericrocis lata (Hymenoptera: Apoidea: Anthophoridae). Am. Mus. Novit. 2985: 1-30

Sabino, W. O., Silva, C. I., Alves-dos-Santos, I. (2017) Mating system and sleeping behaviour of the Male and Female Centris (Paracentris) burgdorfi Friese (Apidae, Centridini). J. Insect. Behav. 30 (1): 103-118

Schmickl, T., Crailsheim, K. (2001) Cannibalism and early capping: strategy of honeybee colonies in times of experimental pollen shortages. J. Comp. Physiol. A. 187(7): 541-547

Scriber, J. M., Slansky, F. (1981) The nutritional ecology of immature insects. Annu. Ver. Entomol. 26(1): 183-211

Silva, C. I., Imperatriz-Fonseca, V. L., Groppo, M., Bauermann, S. G., Saraiva, A. A., et al. (2014) Catálogo Polínico das Plantas Usadas por Abelhas no Campus da USP de Ribeirão Preto. Holos, Ribeirão Preto.

Simpson, B. B., Neff, J. L., Seigler, D. (1977) Krameria, free fatty acids and oilcollecting bees. Nature. 267(5607): 150-151 
Simpson, B. B., Neff, J. L. (1981) Floral rewards: alternatives to pollen and nectar. Ann. Missouri Bot. Gard. 68(2): 301-322

Simpson, B. B. (1989) Krameriaceae. Flora Neotrop. 1-108

Slansky, F. (1982) Insect nutrition: an adaptationist's perspective. Fla. Entomol. 65(1): $45-71$

Snelling, R. R. (1984) Studies on the taxonomy and distribution of American Centridine bees (Hymenoptera: Anthophoridae). Contr. Sci. Mus. Nat. His. Los Angeles. 347: $1-69$.

Sniffen, C. J., O'connor, J. D., Van Soest, P. J., Fox, D. G., Russell, J. B. (1992) A net carbohydrate and protein system for evaluating cattle diets: II. Carbohydrate and protein availability. J. Anim. Sci. 70(11): 3562-3577

Standifer, L. N. (1967) A comparison of the protein quality of pollens for growthstimulation of the hypopharyngeal glands and longevity of honey bees, Apis mellifera L. (Hymenoptera: Apidae). Insectes. Soc. 14(4): 415-425

Taylor, F. (1981) Ecology and evolution of physiological time in insects. Am. Nat. 117(1), 1-23

Toth, A. L., Robinson, G. E. (2005) Worker nutrition and division of labour in honeybees. Anim. Behav. 69(2): 427-435

Turner, R. M., Brown, D. E. (1982) Sonoran desertscrub. Desert Plants. 4: 181-221

Vinson, S. B., Williams, H. J., Frankie, G. W., Shrum, G. (1997) Floral lipid chemistry of Byrsonima crassifolia (Malpigheaceae) and a use of floral lipids by Centris bees (Hymenoptera: Apidae). Biotropica. 76-83

Vinson, S. B., Frankie, G. W., Williams, H. J. (1996) Chemical ecology of bees of the genus Centris (Hymenoptera: Apidae). Fla. Entomol. 72 (2): 109-129

Vinson, S. B., Frankie, G. W., Williams, H. J. (2006) Nest liquid resources of several cavity nesting bees in the genus Centris and the identification of a preservative, levulinic acid. J. Chem. Ecol. 32(9): 2013-2021

Vogel, S. (1974) Ölblumen und ölsammelnde Bienen. Trop. Subtrop. Pflanzenwelt. 7: 285-547

. (1990) History of the Malpighiaceae in the light of the pollination ecology.

Mem. N. Y. Bot. Gard. 55: 130-142

Wimer, L. T., Lumb, R. H. (1967) Lipid composition of the developing larval fat body of Phormia regina. J. Insect. Physiol. 13(6): 889-898 
Willmer, P., Stone, G. (1997) Temperature and water relations in desert bees. J. Therm. Biol. 22(6): 453-465

Zanella, F. C. V. (2002) Sistemática, filogenia e distribuição geográfica das espécies sul-americanas de Centris (Paracentris) Cameron, 1903 e de Centris (Penthemisia) Moure, 1950, incluindo uma análise filogenética do "grupo Centris” sensu Ayala, 1998 (Hymenoptera, Apoidea, Centridini). Rev. Bras. Zool. 46: 435-488 


\section{Supplementary Material}

\section{The description of the Parkinsonia pollen grains}

Parkinsonia florida: pollen grain monad, median size, polar axis measuring $30.49 \pm 2.91 \mu \mathrm{m}(25.44-36.64)$, equatorial diameter $26.07 \pm 2.37 \mu \mathrm{m}(21.38-31.11)$, tricolporate, brevicolpate, pore lalongate, amb subtriangular, oblate spheroidal to prolate, $\mathrm{P} / \mathrm{E} 1.18 \pm 0.15 \mu \mathrm{m}(0.96-1.68)$, exine $1.48 \pm 0.16 \mu \mathrm{m}(1.22-1.89)$, reticulate ornamentation.

Parkinsonia microphylla: pollen grain monad, median size, polar axis measuring $26.49 \pm 1.23$ (24.34-29.77), equatorial diameter $16.76 \pm 1.48$ (22.13-28,78), tricolporate, brevicolpate, pore lalongate, amb subcircular, oblate spheroidal to prolate, P/E $0.99 \pm 0.08$ (0.92-1.35), exine $1.50 \pm 0.17$ (1.15-1.86), reticulate ornamentation.

The shape of the grain allows to separate the two species. However, there are still sizes overlap. Therefore, the two species should be considered as two pollinic types.
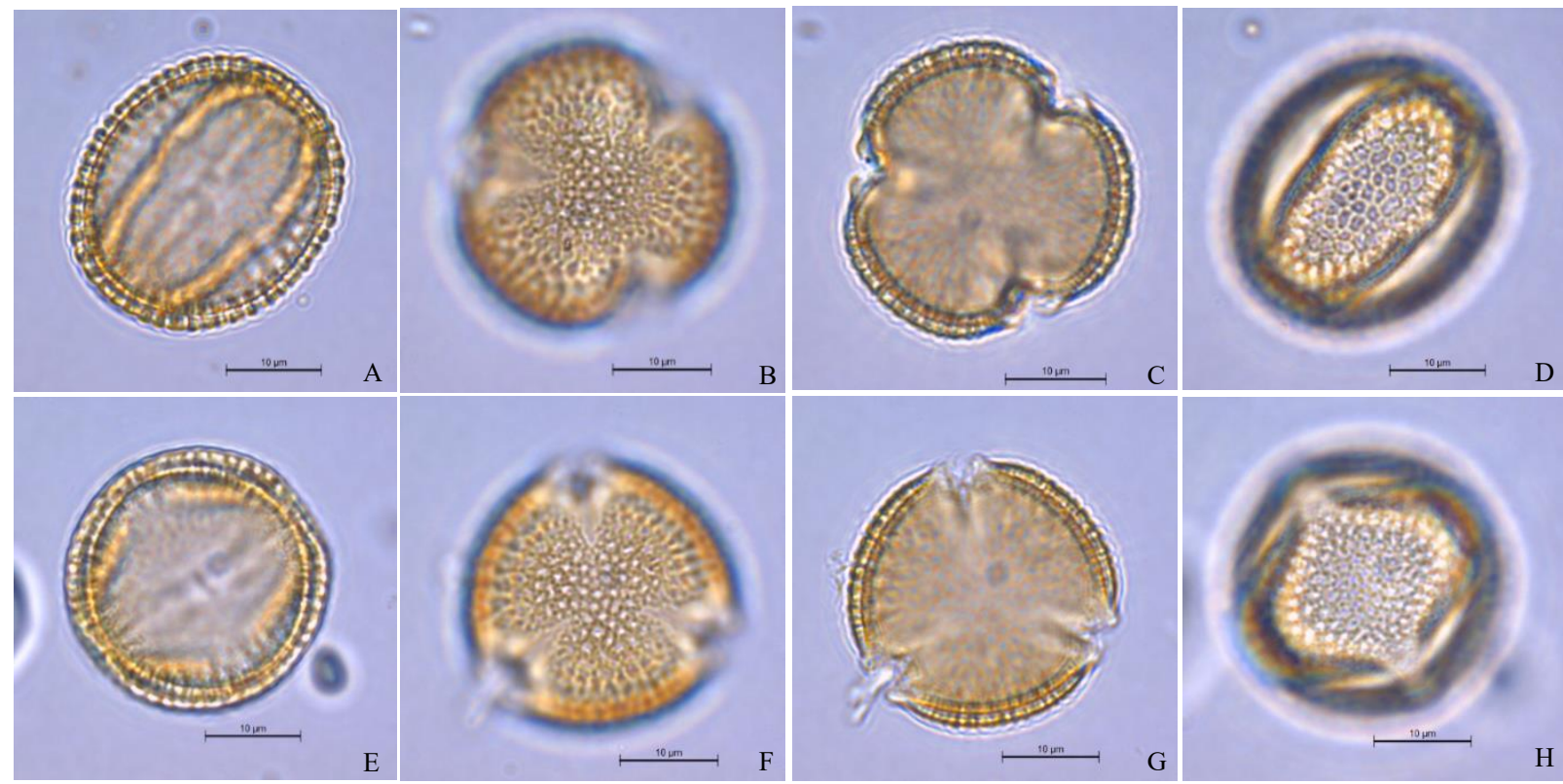

Supp 1. Pollen grains of Parkinsonia florida (A-D) and Parkinsonia microphylla (E-H) 
CONSIDERAGCSÕES EINPAIS 


\section{CONSIDERAÇÕES FINAIS}

Este estudo contribuiu de maneiras diferentes para o entendimento da história natural de Centris (Paracentris) burgdorfi. Mostramos, em detalhe, uma história que começa com o nascimento de fêmeas, que acasalam e iniciam a construção do ninho. Apresentamos o processo de nidificação, passo a passo e, no final, avaliamos a composição de sua dieta, bem como o valor nutricional do alimento.

\section{* Informações sobre o sistema de acasalamento da espécie}

As abelhas estão entre os insetos mais bem estudados do mundo e temos uma quantidade considerável de informações publicadas a cada ano. No entanto, o conhecimento sobre os sistemas de acasalamento de espécies solitárias é muito escasso, muitas vezes pela dificuldade em encontrar o local onde as espécies se acasalam. Relatamos a história de como os machos de Centris burgdorfi procuram as fêmeas. Os machos atingem sua atividade máxima entre 09:00 e 10:30h pela manhã. Alguns machos morrem escavam as dunas petrificadas em busca das fêmeas que ainda não surgiram. Embora a proporção de machos para fêmeas seja de 1: 1, a razão sexual operacional, com os machos emergindo antes das fêmeas, torna a competição por fêmeas extremamente severa. Além disso, não há evidência de que as fêmeas de $C$. burgdori se acasalem mais de uma vez.

\section{* Uma abelha que quebra paradigmas ao dormir}

Geralmente, nas abelhas solitárias, as fêmeas passam a noite nos ninhos que estão construindo (ou na vizinhança deles), enquanto os machos passam a noite nas plantas. Em nosso estudo, temos o primeiro relato de uma situação inversa: os machos de C. burgdorfi passam a noite no local de nidificação, enquanto as fêmeas passam a noite nas plantas que usam como fonte de óleo floral - Krameria tomentosa. Esse comportamento incomum (observado durante dois anos consecutivos) nos levou a hipotetizar que os machos estão sob alta pressão de competição para conseguir um acasalamento. Dormir no lugar de nidificação permitiria um acesso rápido às fêmeas virgens que emergem com o nascer do sol. Para as fêmeas, passar a noite sobre as 
plantas que utilizam como fonte de óleo representa um fácil acesso aos elaióforos no início da manhã. Fêmeas marcadas nas plantas durante a noite chegaram nos ninhos na manhã com suas escopas cheias de óleo floral.

\section{Construindo o ninho}

Após o acasalamento a fêmea imediatamente começa um novo ninho. Através de filmagens feitas dentro dos ninhos relatamos todo o processo de nidificação, desde o momento da escavação até o fechamento da última célula. As fêmeas precisam de 2,62 dias, em média, para construir uma célula de cria, o que é considerado um tempo elevado em comparação com outras espécies de Centris. Células destinadas a fêmeas são, em média, maiores do que as destinadas a machos. A maior atividade de coleta de recursos ocorre no período da manhã. Nós medimos a temperatura dentro e fora dos ninhos simultaneamente e descobrimos que, embora a temperatura externa quase atingisse $40^{\circ} \mathrm{C}$, a temperatura dentro dos ninhos raramente passa dos $28^{\circ} \mathrm{C}$, o que poderia ser importante para a sobrevivência das larvas.

\section{* A plasticidade do nicho trófico}

A avaliação do nicho trófico de três populações distintas de Centris burgdorfi (separados por pelo menos $1400 \mathrm{~km}$ ) mostrou que, em cada população, as fontes de pólen e néctar variam, e poucos gêneros de plantas foram compartilhados. As fêmeas de C. burgdori não coletam óleo em Malpighiaceae, mesmo se várias espécies de plantas desta família estiverem presentes na área. Além disso, as fêmeas foram capazes de coletar óleo floral em plantas com diferentes tipos de elaióforos: no Sul, as fêmeas coletam óleo floral em Angelonia integerrima, uma planta com elaióforo tricomático, enquanto no Centro-Oeste e Nordeste coletam óleo em Krameria, uma planta com elaióforo epitelial. A plasticidade do nicho torna $C$. burgdorfi amplamente distribuída em todo o Brasil. As espécies podem viver em ambientes completamente diferentes em termos de vegetação. 
Comparamos a dieta de C. burgdorfi a uma espécie próxima, que habita o deserto de Sonora no Arizona, EUA: Centris (Paracentris) pallida. Esta espécie perdeu o comportamento de coleta de óleo ao longo do tempo evolutivo. Foram coletadas 69 células de $C$. pallida nos EUA e 69 células de $C$. burgdorfi no Brasil. Analisamos nutricionalmente a dieta e descobrimos que a de $C$. burgdorfi é mais rica em proteínas e lipídios, enquanto a de $C$. pallida é mais rica em carboidratos. Os resultados corroboram o fato de que as plantas com anteras poricidas têm uma maior porcentagem de proteínas quando comparadas às plantas sem antera poricida (C. burgdorfi usa, principalmente, plantas do gênero Chamaecrista, enquanto C. pallida é especializada em Parkinsonia e Olneya). Além disso, a quantidade de carboidratos presentes nas células de C. burgdorfi mostra que as fêmeas estão usando néctar juntamente com o pólen e óleo em suas provisões. 